\title{
EVALUATION OF SUSTAINABILITY ASSESSMENT TOOLS FOR ROAD CONSTRUCTION PROJECTS \\ APPLIED ON AN ASPHALT ROAD REHABILITATION PROJECT IN GERMANY
}

\author{
by \\ Bettina Ziller, BEng 2015, BSc 2014 \\ Karlsruhe, Germany, 2016
}

A Master's Project

presented to University of Applied Science Karlsruhe

and

Ryerson University, Toronto

in partial fulfillment of the

requirements for the degree of

Master of Engineering

in the Program of

Civil Engineering

Toronto, Ontario, Canada 2017

(c) Bettina Ziller 2017 


\section{Author's Declaration}

AUTHOR'S DECLARATION

I hereby declare that I am the sole author of this MRP. This is a true copy of the MRP, including any required final revisions.

I authorize Ryerson University to lend this MRP to other institutions or individuals for the purpose of scholarly research.

I further authorize Ryerson University to reproduce this MRP by photocopying or by other means, in total or in part, at the request of other institutions or individuals for the purpose of scholarly research. I understand that my MRP may be made electronically available to the public. 
Bettina Ziller, BEng, BSC

\title{
EVALUATION OF SUSTAINABILITY ASSESSMENT TOOLS FOR ROAD CONSTRUCTION PROJECTS
}

\author{
APPLIED ON AN ASPHALT ROAD REHABILITATION PROJECT IN GERMANY \\ Master of Engineering • Civil Engineering • 2017 \\ University of Applied Science Karlsruhe - Ryerson University, Toronto
}

\begin{abstract}
The increasing awareness of the need for sustainable development in road construction and the growing number of different assessment tools worldwide has led to a general demand for a tool specific to the German market with its current environment and regulations.

This thesis briefly reviews the overall development of the sustainability concept and then applies different tools for the evaluation of road constructions using the example of a small rehabilitation project in Germany. Further, a brief overview of the existing international and European standards and guidelines will be given, followed by a more detailed description of the Swiss method NISTRA, the application of the British asPECT, the Canadian Athena Pavement LCA and the French SEVE.

Partly limited access to the tools and the small amount of available data due to the project size has led to rather limited results and it remains to be seen if a bigger project and a better access would result in a more sophisticated outcome. It can therefore be concluded that the sustainability evaluation tool for small rehabilitation projects specific to Germany would need a more simplified handling and structure then what is currently available.
\end{abstract}




\section{Table of Contents}

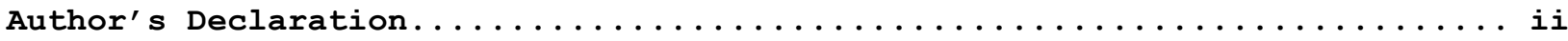

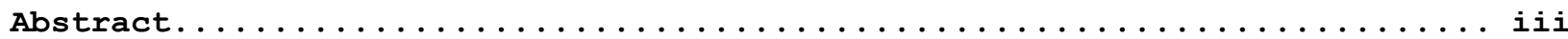

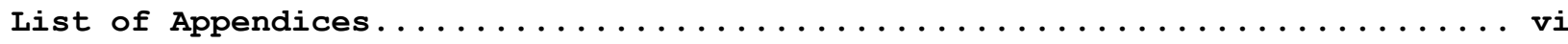

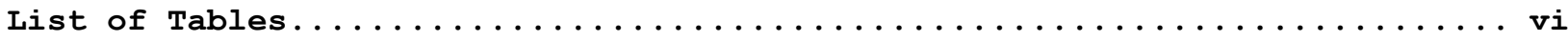

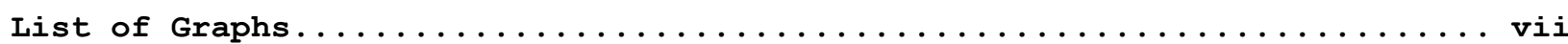

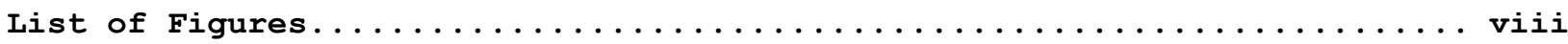

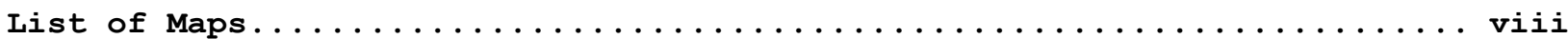

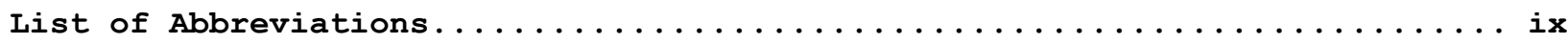

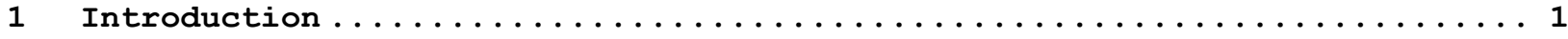

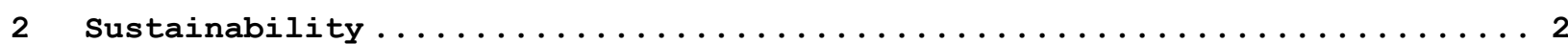

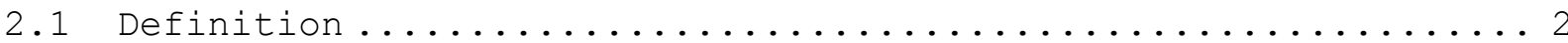

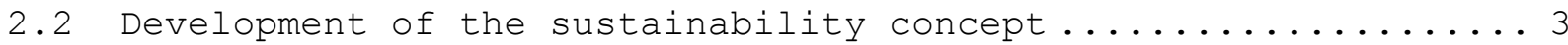

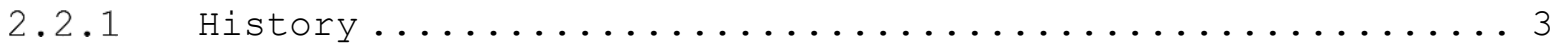

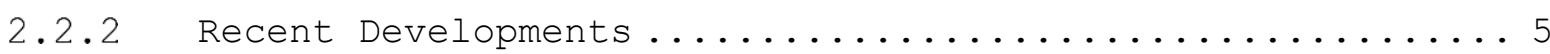

2.3 Recent Discussions in the Public and among Experts .........7

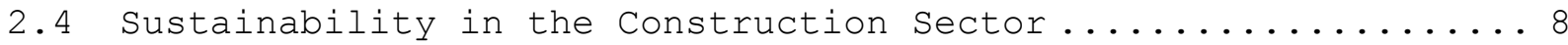

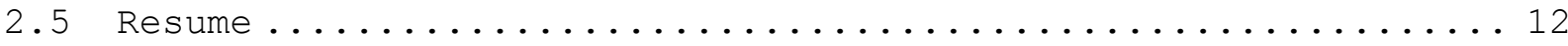

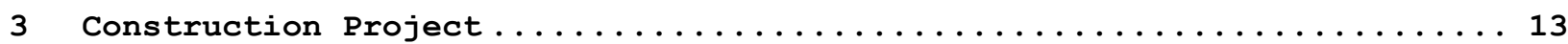

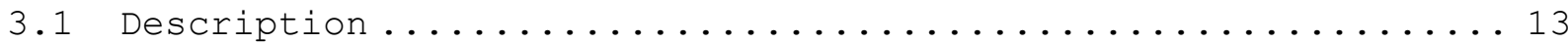

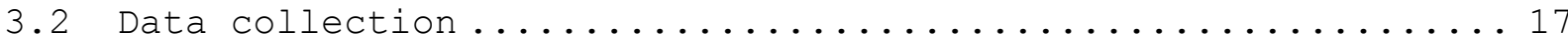

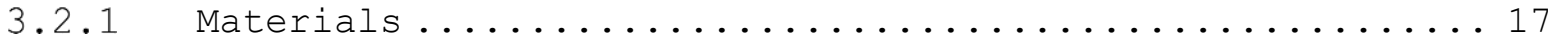

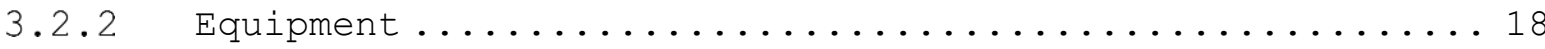

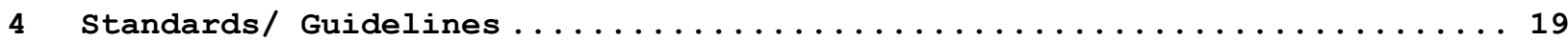

4.1 ISO 14040 Series - Life Cycle Assessment ...............22

4.2 EN 15804 - Environmental Product Declaration.............24

4.3 Swiss Guidelines for Sustainability Evaluation of Road

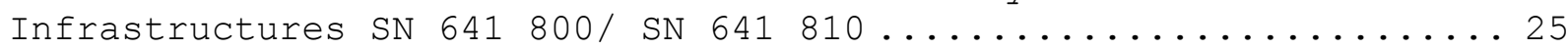

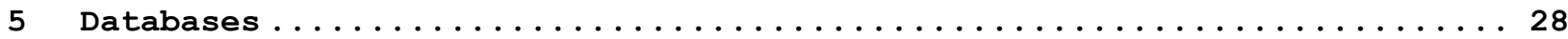

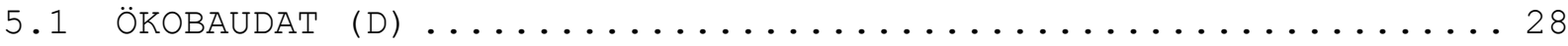

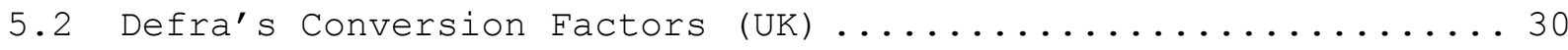

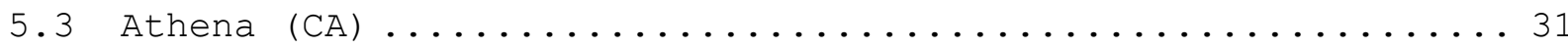

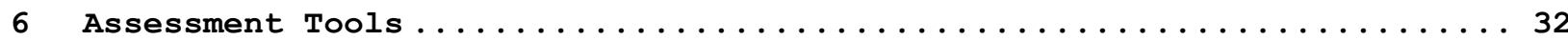

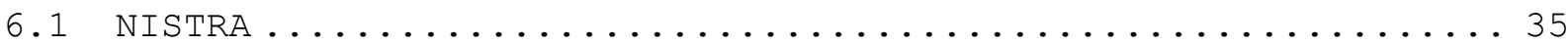

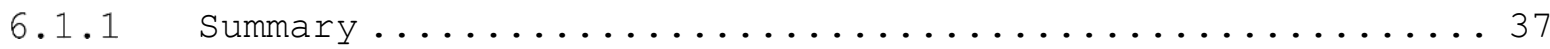

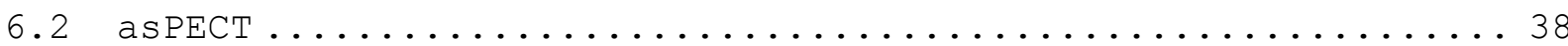




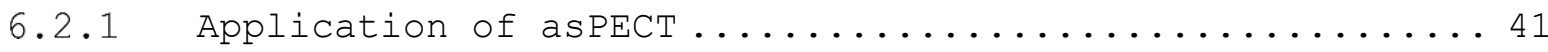

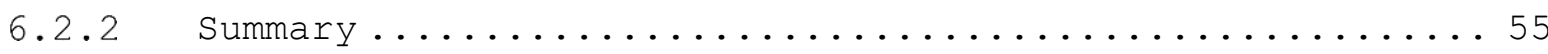

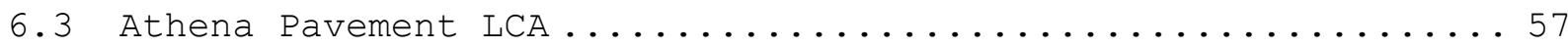

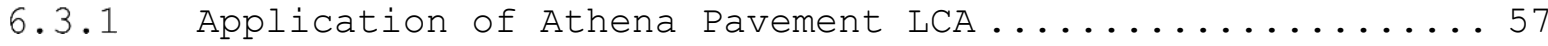

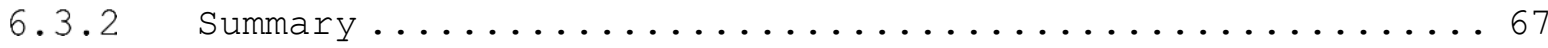

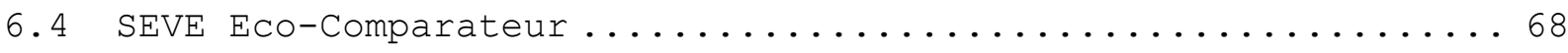

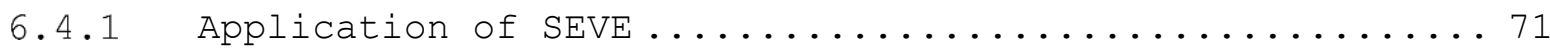

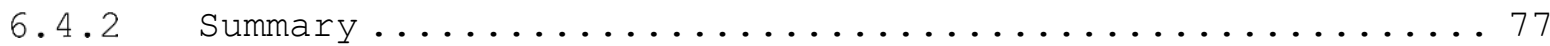

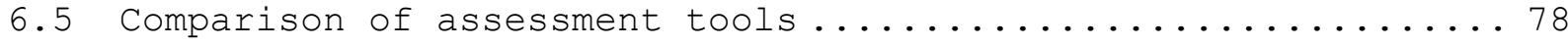

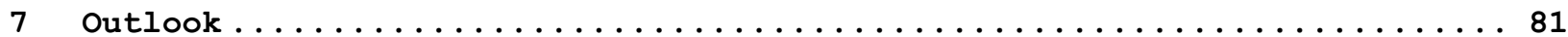

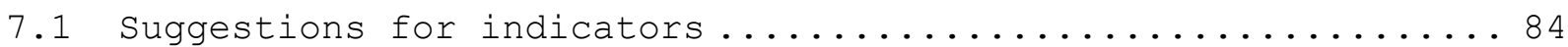

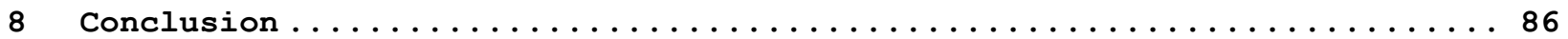

Appendices ..................................

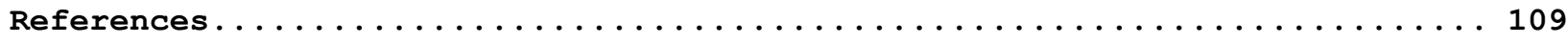




\section{List of Appendices}

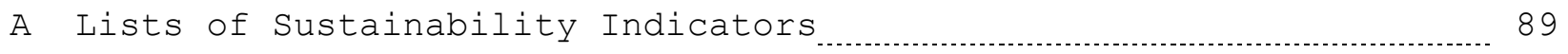

B Results asPeCT

C Results Athena Pavement LCA 105

D Results SEVE 108

E $\quad C D$

\section{List of Tables}

Table 3-1: Summary of materials used for the rehabilitation of K3533 17 Table 4-1: Overview of Swiss standards concerned with sustainability in

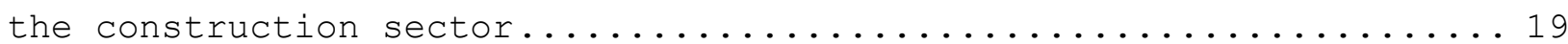
Table 4-2: Overview of international standards concerned with

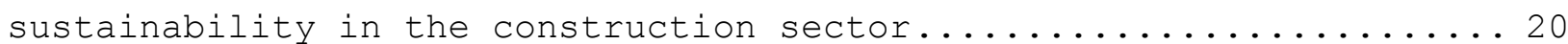
Table 4-3: Overview of European standards concerned with sustainability

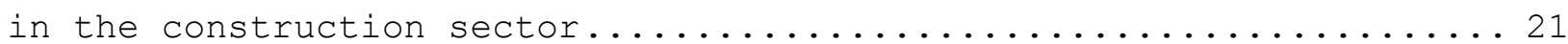

Table 5-1: Example of conversion factors for diesel...........30 Table 5-2: Example of CO2e emissions of construction materials..... 31

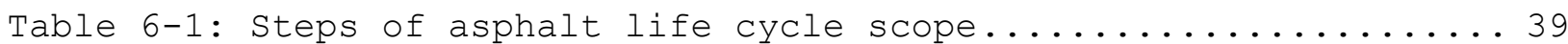
Table 6-2: Information needed for creation of materials used......42 Table 6-3: Information needed for creation of plant..........43

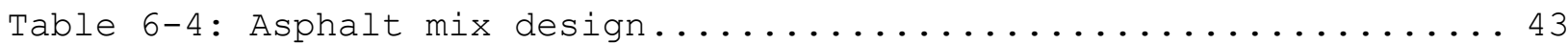
Table 6-5: Input data to create new project...............44

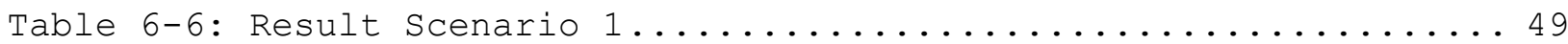
Table 6-7: Distribution of impact of life-cycle steps on overall

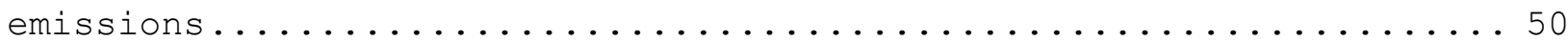
Table 6-8: General project information.................. 58

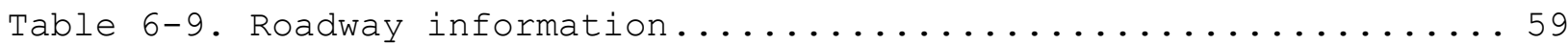
Table 6-10: Details about roadway design...................59 Table 6-11: List of construction equipment................60 Table 6-12: Distribution of impact of life-cycle stages........63 Table 6-13: Chosen materials for road layers and associated consumption

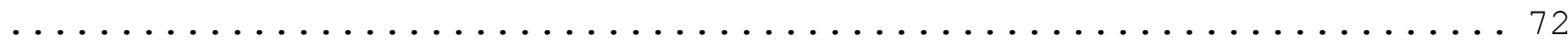

Table 6-14: Comparison of different emissions..............78 Table 6-15: Comparison of assessment tools.................79 
Table 7-1: Suggested Indicators for Germany............... 85 Table 8-1: Sustainability performance indicators for road structures,

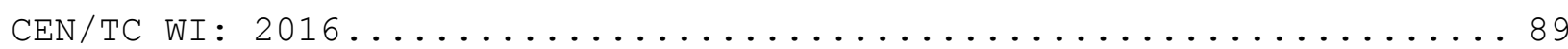

Table 8-2: Swiss Target System Catalogue of Indicators..........990 Table 8-3: Likely composition of indicators of EDGAR project......91

\section{List of Graphs}

Graph 6-1: Illustration of impact distribution of life-cycle steps,

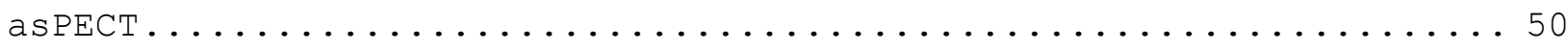
Graph 6-2: Impact of asphalt composition on Total $\mathrm{kgCO}_{2} \mathrm{e}$, asPECT ... 51 Graph 6-3: Impact of traveled distances on Total $\mathrm{kgCO}_{2} \mathrm{e}$, asPECT.... 53 Graph 6-4: Impact of excavation treatment on Total $\mathrm{kgCO}_{2} \mathrm{e}$, asPECT ... 54 Graph 6-5: Summary of results for Scenario 0, Athena..........63 Graph 6-6: Illustration of impact distribution of life-cycle steps,

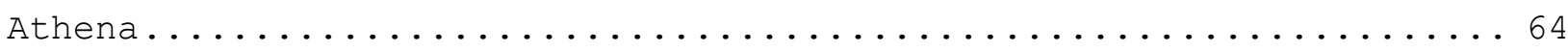
Graph 6-7: Impact of different distances on Global Warming Potential in

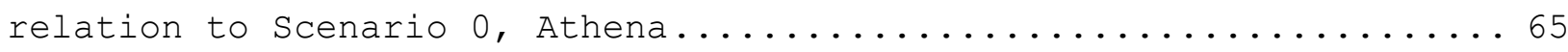
Graph 6-8: Impact of different road section lengths on Global Warming Potential in relation to Scenario 0 , Athena...............66 Graph 6-9: Illustration of distribution of energy consumption of life-

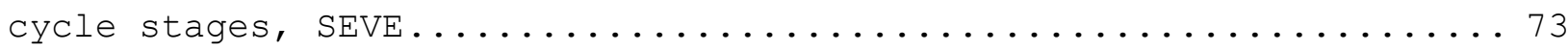
Graph 6-10: Illustration of distribution of $\mathrm{CO}_{2}$ emissions of life-cycle

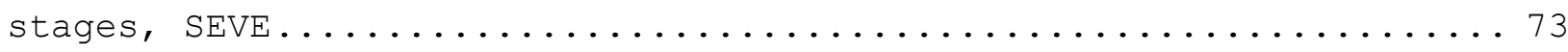
Graph 6-11: Illustration of impact of distances on energy consumption,

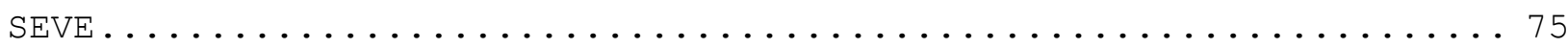
Graph 6-12: Illustration of impact of distances on $\mathrm{CO}_{2} \mathrm{e}$ emissions, SEVE

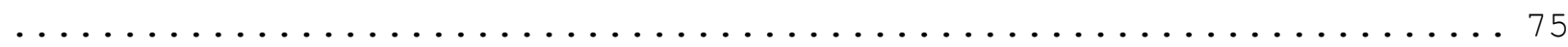

Graph 6-13: Illustration of impact of construction time on energy

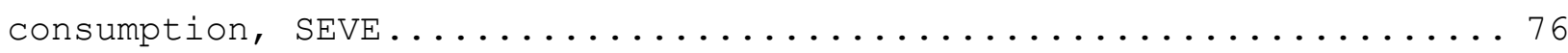
Graph 6-14: Illustration of impact of construction time on $\mathrm{CO}_{2} \mathrm{e}$

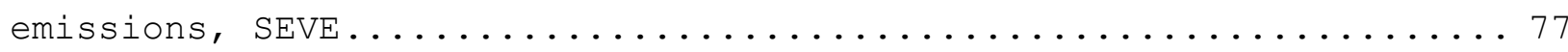




\section{List of Figures}

Figure 1-1: EU Sustainable Development Strategy............... Figure 2-2: Asphalt production and recycled asphalt in million tons in

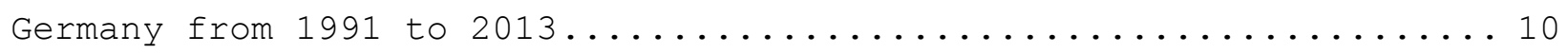

Figure 3-1: Illustrative Cross section of K3533.............. 15

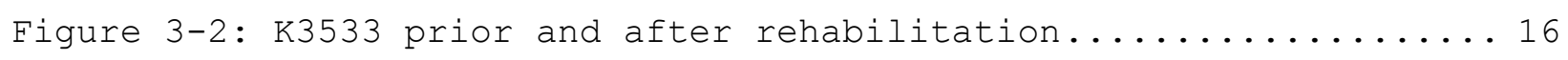

Figure 5-1: Life-cycle stages EN $15643-2 \ldots \ldots \ldots \ldots \ldots \ldots \ldots \ldots \ldots$

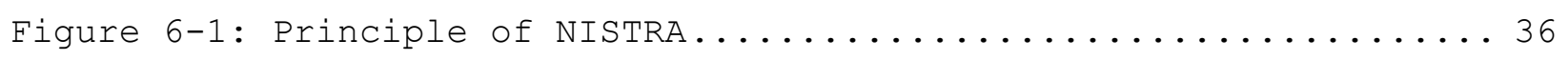

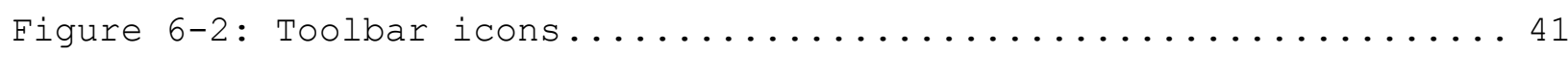

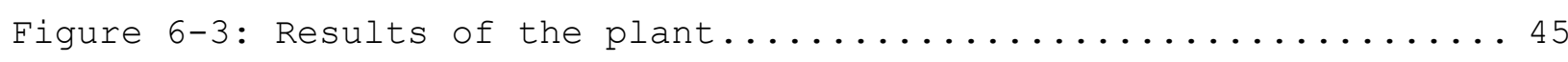

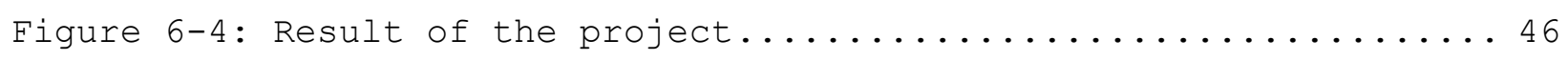

Figure 6-5: Report summary of the plant and the project........47

Figure 6-6: Cross section generated by Athena................ 59

Figure 6-7: Partial LCA considered with SEVE................69

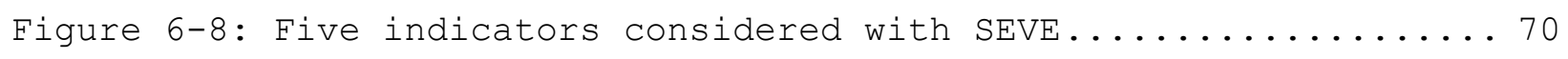

Figure 7-1: Information Quality Levels (IQL) concept............83

\section{List of Maps}

Map 3-1: Map of Germany, location of construction project highlighted

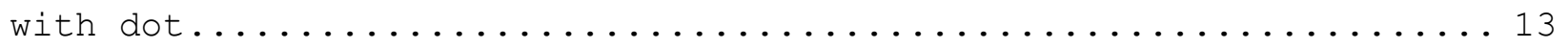
Map 3-2: Map with location of construction project............ 14 Map 3-3: Map with road section in question $(1: 20000) \ldots \ldots \ldots \ldots$ 


\section{List of Abbreviations}

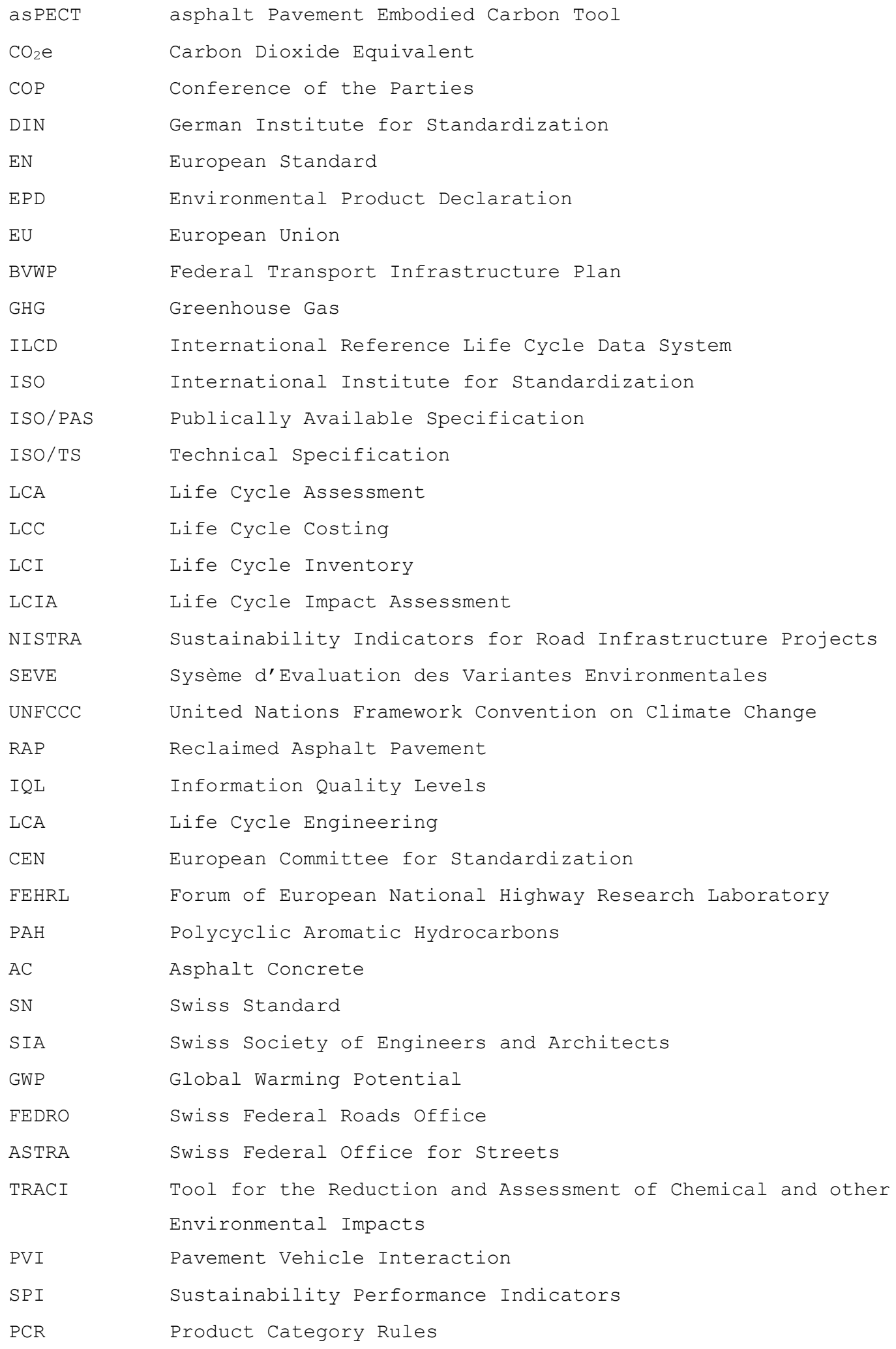




\section{Introduction}

Political discussions have been influenced by the need for sustainable development since numerous years. Supported by that the increasing application of sustainable products and practices in the economy has been backed by the publication of standards and guidelines. Especially for structural constructions and buildings comprehensive standards, guidelines and tools for the sustainability assessment such as the European Standards series EN 15643 have been published. Some of them have been transferred to infrastructures, especially road constructions, however there are no specific resources for the infrastructure sector available in Germany.

Recent sustainability concepts consider and take into account the $\mathrm{CO}_{2}$-footprint and other indicators related to all three sustainability pillars associated with a construction project, which are environment, social and economic. A widely recognized and used concept is the lifecycle assessment method (LCA) calculating among others the $\mathrm{CO}_{2}$-footprint of products and constructions. When using an LCA, data for all phases of the life-cycle are collected and analysed to calculate a detailed environmental impact.

Different tools and methods generally concerned with new constructions already exist in different countries which support the data collection and analysis based on standards, guidelines and local practices. Such a tool does not yet exist for the German infrastructure sector.

This dissertation is investigating how these tools are working, what results they are generating and if they can be applied to the current German politics. In Germany 70 of the available budget for the period until 2030 has been allocated to the rehabilitation of the existing road network, whilst the remaining $30 \%$ will be invested into the construction of new roads [1]. 
The scope of this dissertation is to evaluate existing tools and concepts and if and in what way they could be applied to the current situation in Germany •

\section{Sustainability}

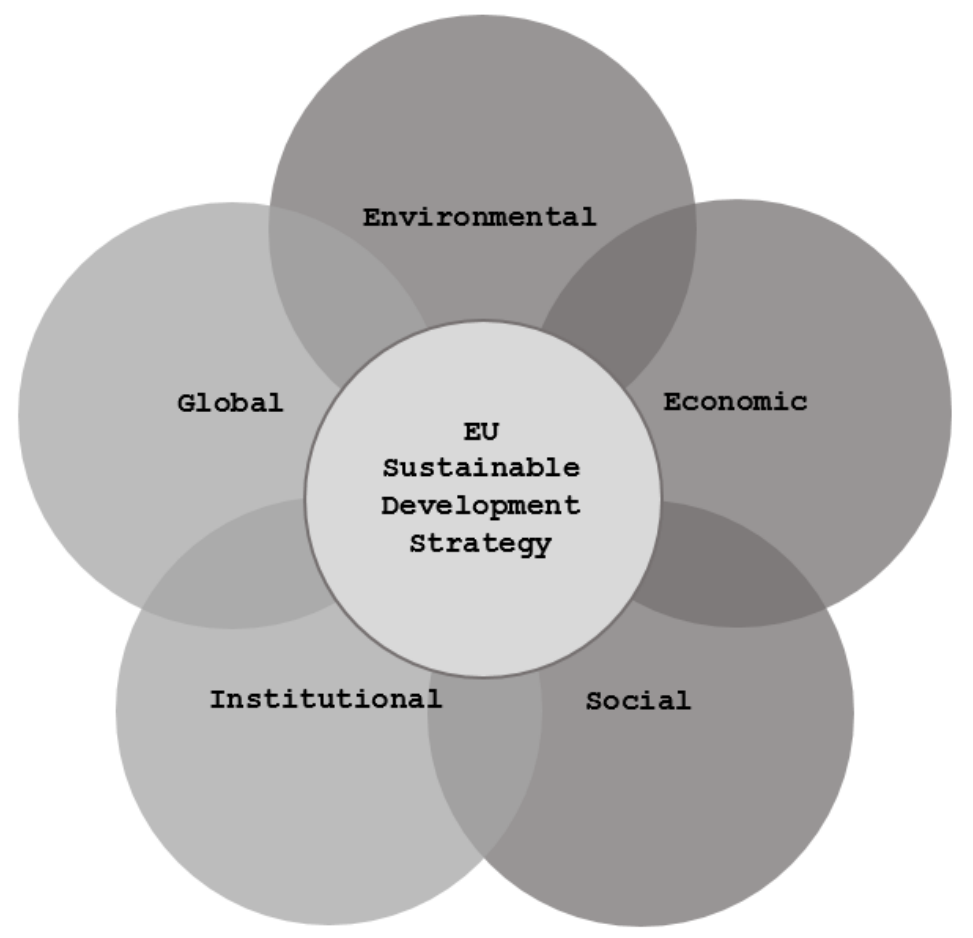

Figure 1-1: EU Sustainable Development Strategy

\subsection{Definition}

"The future we want" is the title of a resolution the United Nations commit themselves to in order to promote sustainable development ensuring an economically, socially and environmentally sustainable future for future and present generations [2]. Based on this vision the European Union developed their Sustainable Development Strategy consisting of five fields as illustrated by Figure 1-1. The aim of the UN is the pursuit of economic progress while safeguarding the natural environment and promoting social justice. In addition to these three dimensions the European Union extended their sustainable development strategy by an 
institutional element, the adoption of good governance practice in the EU and a global element, the promotion of a global partnership for worldwide sustainable development. The institutional element involves according to their strategy, among other goals the openness of EU institutions, the effectiveness of policies and the coherence of policies and actions within the EU. Goals such as the promotion of multilateral sustainability agreements, inclusion of sustainable practices in EU external policies and supporting of sustainable development in leastdeveloped countries have been summarized under the label 'global partnership' . [3]

\subsection{Development of the sustainability concept}

\subsubsection{History}

The arms race, environmental deterioration, the population explosion, and economic stagnation are the major problems of humanity and how fast and effective they are dealt with will be crucial for the faith of mankind, probably even its survival. This has been declared in 1972 by the club of Rome in the book 'The Limits of Growth', a nontechnical report about their findings. The club of Rome's report, 'The Predicament of Mankind' was the first scientific report about the likely future of the world, if there is no change in the mindset and behavior of decision makers and the population in terms of accelerating industrialization, rapid population growth, widespread malnutrition, depletion of nonrenewable resources, and a deteriorating environment. [4]

Today, 40 years later research has shown that the current situation corresponds to the scenario of the book called 'business-as-usual', meaning a zero-solution, nothing changes in the attitude of the world. Even though some have criticised the book this shows that its scenarios are quite accurate. $[5,6]$ 
In June 1972 the United Nations Conference on the Human Environment in Stockholm, Denmark stated in their declaration following the conference:

"To defend and improve the human environment for present and future generations has become an imperative goal for mankind - a goal to be pursued together with, and in harmony with, the established and fundamental goals of peace and of worldwide economic and social development." [7, p. 6].

This conference was the first international meeting discussing sustainability on a global scale. [7]

One of the next milestones of the sustainability development is the publication 'Our Common Future' following the meeting of the World Commission on Environment and Development in Oslo, Norway in 1983, known as the 'Brundtland Report', leading to the most quoted definition of sustainability: "Humanity has the ability to make development sustainable to ensure that it meets the needs of the present without compromising the ability of future generations to meet their own needs." [8, p. 27]. [8]

In 1992, 172 counties met in Rio de Janeiro, Brazil at the United Nations Conference on Environment and Development leading to the Agenda 21, a plan of action to achieve sustainable development and the United Nations Framework Convention on Climate Change (UNFCCC), a multilateral agreement on climate change. Today 185 countries have ratified this agreement about the prevention of man-made interference in the earth's climate system and promotion of the stabilization of greenhouse gas production. The main concern of the UNFCCC is to enable the ecosystem to adapt to the climate change, to ensure sufficient food production and to promote sustainable economic development. [9, 10]

Up to the present day 21 Climate Conferences of the Conference of the Parties (COP), the supreme decision making body of the UNFCCC, have been held. The third meeting of the COP in Kyoto, Japan in 1997 resulted in 
the Kyoto Protocol, the first treaty to include binding agreements on the reduction of emissions. Up to the present time 191 countries have ratified it whereas America has still not ratified it and Canada withdrew in 2012. Decisions about the structure and implementation of the Kyoto Protocol have been made in the consecutive conferences, especially on the seventh COP in Marrakesh, Morocco in 2001. [11, 12]

\subsubsection{Recent Developments}

In September 2015 new 'Sustainable Development Goals' have been agreed on by the United Nations as part of the 2030 Agenda for Sustainable Development', a collection of 17 goals and 169 secondary goals to replace the 'Millennium Development Goals' expiring in 2015. The new goals are supposed to have some advantages with respect to the Millennium Goals even though they have been criticised that they are voluntary and in some areas misleading, vague and contradictory. Among other advantages the Sustainable Development Goals are addressed to all countries, not just developing countries and the goals take into account the interaction of the different dimensions of the sustainability goals. Furthermore, the development of the collection of goals has been made over a three year open and transparent process allowing a better identification of the member states of the UN with them. [13]

The most recent COP took place in Paris, France from 30 November to 11 December 2015. One of the major outcomes of the conference is the Paris Agreement, where 195 countries agreed for the first time on a legally binding global climate deal which is to be entering into force in 2020 if 55 countries, which are responsible for 55\% of global emissions to date, ratify the agreement. With the ratification of the agreement by the EU Parliament the conditions are fulfilled and the agreement can enter into force on $4^{\text {th }}$ November 2016, four years earlier than expected. [14] 
The Paris Agreement is a guideline for the climate policy starting 2016 and contains among others the goal to limit the global warming with respect to post industrialization to $2^{\circ} \mathrm{C}$ and set the net-greenhouse-gas emission to zero in the next half of this century. Differences to previous climate agreements are that rather than focusing on multilateral measures for the reduction of greenhouse gases the Paris Agreement is based mainly on implementing national climate agendas. By ratifying this agreement, nations agree to submit every five years progress reports on how they are progressing in achieving their national climate goals. The next COP will be in Marrakesh, Morocco in 2016 and its aim will be to put the Paris Agreement into action. [15, 16]

During the conference in Paris Germany was one of the countries pressing for more ambitious goals and stricter regulations for the participating countries. However, this attitude is not wholly reflected in the national climate policy of Germany. A rapid fossil-fuel phase-out is crucial for achieving the goals written down in the Paris Agreement, however, the German Economics Minister said, that a phase-out is not manageable in the near future. Furthermore, the German Government just updated the Erneuerbare-Energien-Gesetz ${ }^{1,2}$ implying that the share of wind energy is to be reduced over the next years and a reduction of the incentive to produce wind energy will be implemented, renewable energy might even will be part of the general competition of the energy sector. The effects of the law for the wind energy sector will be that without the expected incentives promised during the planning phase of new wind turbines the operation of them will not be economic for the operators, especially for small investors. [17]

1 Specific terms in a language other than English are used in the original language in the text and an analogous translation is included as a footnote

2 Renewable Energy Act 
Another indication for the reluctance of the German Government to implement the goals of the Paris Agreement is the Bundesverkehrswegeplan ${ }^{3}$ 2030 (BVWP) published in the beginning of August 2016. The new plan is allocating $49.4 \%$ of future investments into the road sector and only 41.3\% into the rail sector, 9.3\% are allocated to the waterway sector, instead of the 40:60 ratio in favor of the rail and waterway sector requested by the environment ministry and environmental organisations. The BVWP is furthermore criticised that it is neglecting the environmental aspect of the transportation sector. The BUND, a German environmental organisation claims that over 10 million tonnes of $\mathrm{CO}_{2}$ emissions could be saved each year if the traffic would be transferred to the rail and waterway sector. [1, 18, 19]

\subsection{Recent Discussions in the Public and among Experts}

Even though over the past decades many conferences have been held and reports have been published there are always voices claiming that not enough is being done to circumvent the threats the current development poses to our future. Two of them being the British Economist and a former Chief Economist of the World Bank Nicolas Stern and the Canadian journalist and globalization critic Naomi Klein.

Nicolas Stern gave many lectures and published reports and books, among others the book 'Stern Review on the Economics of Climate Change' (2006). In his so called Stern Review he assessed the costs and risks of climate change and compared them for the scenarios if there is no change in the human actions and if we take strong action now. Some of his findings are, that the cost of not acting is much higher than the cost of action, no action is estimated to cost 5\% of the global GDP each year, action, meaning the rapid reduction of greenhouse gases, only 1\% of the global

\footnotetext{
3 Federal Transportation Infrastructure Plan
} 
GDP each year. Stern claims that the decisions made now could have an impact comparable to the ones associated with the great wars and the great depression in the first half of the $20^{\text {th }}$ century. The changes happening now are claimed to be not reversible. The Stern Review has been met with great praise within the scientific world and is said to be an important guide for the decision makers. [20, 21]

Naomi Klein published many articles for among others the New York Times, the Boston Globe and the Blätter für Deutsche und Internationale Politik as well as various books, the most recent one being 'This Changes Everything - Capitalism vs. Climate Change' (2014). Two years ago Naomi Klein held a presentation in Berlin related to the Climate change and her book. She claims for example that the interests of the fossil industry are too often ranking higher than the need to act against the climate change. She is furthermore promoting the potential of the renewable energy industry for investments giving the Rockefeller family as example who said they will use some money made with oil to invest into clean energy. [22, 23]

However, critics say that she is using the topic of climate change to promote her opinion against capitalism and that she is simplifying the issue by solely blaming the big corporations for the climate change and the lack of action against it for the climate change [24].

\subsection{Sustainability in the Construction Sector}

The growing awareness of the necessity for sustainable practices let to various developments in the construction industry and political regulations regarding the construction sector. This section is giving some examples about developments in the asphalt mix design and recycling methods, as well as recent EU-projects for sustainable innovations.

4 German monthly political journal 
Since more than thirty years the asphalt industry has conducted research into the reuse of excavated materials and the material properties of pavement containing recycled material compared to pavement consisting only of virgin material. The performed studies have shown that recycled material can be used for base layers as well as surface layers as long as the recycled material is of good quality and the production process is conducted in plants equipped accordingly. The amount of reused material in hot mix asphalt has increased by 50 from 40 in 1987 to 90 \% in 2013. This development is due to an improvement in the material separation in the milling process, improvements in the mixing process and the increasing consideration of asphalt recycling in standards and construction contracts. Figure 2-2 illustrates the share of recycled asphalt in relation to the overall asphalt production in Germany from 1991 to 2013. It can be seen that about $20 \%$ of the asphalt installed in Germany in 2013 is recycled material compared to about 11 \% recycled material in 1991. The decrease of the overall asphalt quantity can be explained by the increase of rehabilitation projects in Germany compared to the high number of new constructions at the beginning of the 1990s due to the reunification of Germany.[25] 


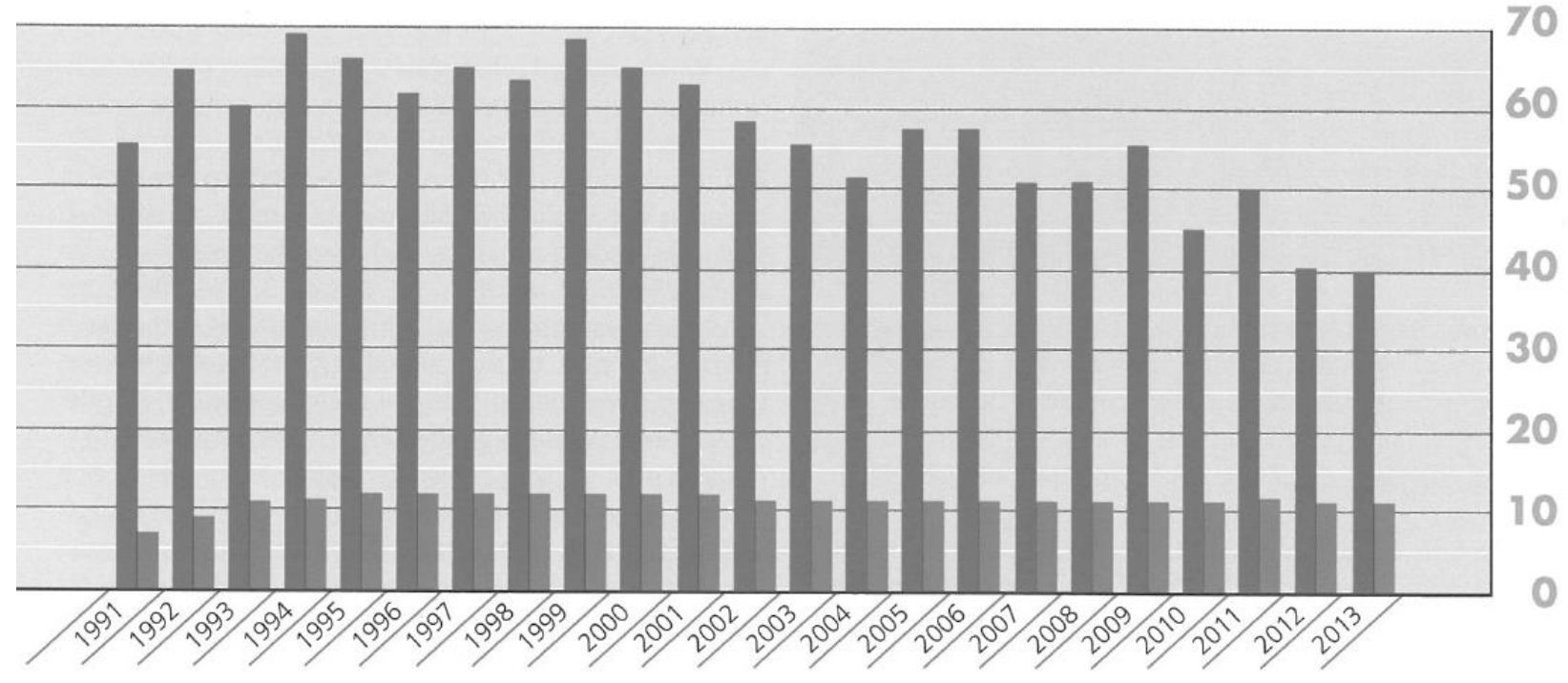

Figure 2-2: Asphalt production (left bar) and recycled asphalt (right bar) in million tons in Germany from 1991 to 2013 [25]

Another progress in the asphalt road construction industry is the development of new sustainable on site recycling techniques such as hot and cold mix recycling. Hot mix recycling can be performed on site using solely the excavated material or adding additional material such as bitumen, aggregates or additives. The material is heated up and loosed up to the depth needed so that it can be removed gently without the destruction of aggregates and remixed and reinstalled on site by specific equipment. The reinstalled material can be either used as surface layer or as base layer. For cold mix recycling special equipment is used to remove the material and reinstall it as base layer using special binder and additives. The properties of the reinstalled layer depend on the binder combination and the Young's modulus that has been obtained. [25]

Within the EU numerus projects are addressing sustainable development in the road construction sector, a major organisation promoting these projects is FEHRL, the Forum of European National Highway Research Laboratory, an international association comprised of over 30 national research and technical institutes. One of the projects FEHRL is 
participating in, LCE4ROADS, formerly called ECOLABEL will be introduced here.

LCE4ROADS is a project coordinated by the Spanish organisation ACCIONA aiming to develop a certification system for road products and infrastructures with a green, holistic and EU-harmonized approach. LCE4ROADS is integrating the Life Cycle Engineering (LCE) concept considering environmental, economic, social as well as technical indicators for future and existing infrastructures including their construction materials. [26, 27]

The project is comprised of eight work packages:

(1) Setting the scene

(2) Sustainable certification methodology for road products and infrastructures

(3) Assessment against the LCE4ROADS methodology of road products and infrastructures

(4) Development of the LCE4ROADS software tool

(5) Validation of the LCE4ROADS methodology and the associated software

(6) LCE4ROADS guide and implementation strategies

(7) Communication, dissemination, standardisation and exploitation

(8) Administration management

The project is set for 36 months and funded by the European Commission and started on $1^{\text {st }}$ October 2013. The final conference will be held on $17^{\text {th }}$ November 2016 in Brussels where all project results will be presented. To this date these results have not been available. However, a pre-standardisation document has been presented to a group of road experts and a CEN committee for public consultation. At the end of September 2016 a concluding meeting has been held to agree on a final document. [26, 27] 
The temporary document TC WI: 2016 (E) [28] is containing a list of indicators for the sustainability assessment of roads considering all three pillars of sustainability, environmental, social and economic. The table in Appendix A is defining the set of sustainability performance indicators (SPI) of the temporary document. The list is comprised of three main categories: environmental, economic and social and these three main categories are divided into eight sub-categories which are comprised of 21 indicators. For each indicator a definition, the unit and the measurement or calculation method it should be measured in are defined in the document. However, it does not include benchmarks for the indicators or guidelines which indicators should be applied to a specific project and how. [28]

According to the project coordinators LCE4ROADS will over time replace existing country-specific methodologies for the sustainable assessment of roads and road infrastructure. The participants envision that LCE4ROADS will create a new market for organisations involved in sustainability assessment.

\subsection{Resume}

With respect to numerous articles, reports and publications from different institutions it can be said, that sustainability and climate change are a core topic in the public and among scientists and the whole society has to deal with it. Common to all resources reviewed for this thesis is that the climate is changing at a rapid pace and that if nothing is done or if what is done happens to slowly the outcome cannot be predicted with utmost certainty, but all scenarios show a negative future. It still seems to be difficult to find consensus between all interest groups, however the real threat the changing climate poses has to be realised and dealt with. 


\section{Construction Project}

To establish a common foundation for the comparison of the assessment tools a rehabilitation project has been provided by the Landratsamt Karlsruhe ${ }^{5}$. The relevant data has been gathered from the construction file as well as suppliers of construction materials. In the following section the construction projects is described and the relevant data summarized.

\subsection{Description}

A basic rehabilitation project of a Landstraße ${ }^{6}$ (K 3533) has been provided by the Landratsamt Karlsruhe with the associated data about materials and equipment used. The road K 3533 is located in the south-west of Germany as can be seen on Map 3-1. Generally, district roads are for local traffic and with low traffic volume. Roads of this class have one lane with a width of $6 \mathrm{~m}$ and $1.5 \mathrm{~m}$ shoulders with markings on each side which can be crossed if necessary, instead of a marking in the middle of the road. The absence of a marking in the center of the road is indicating to the driver that heightened awareness is necessary in case of oncoming traffic. [29]

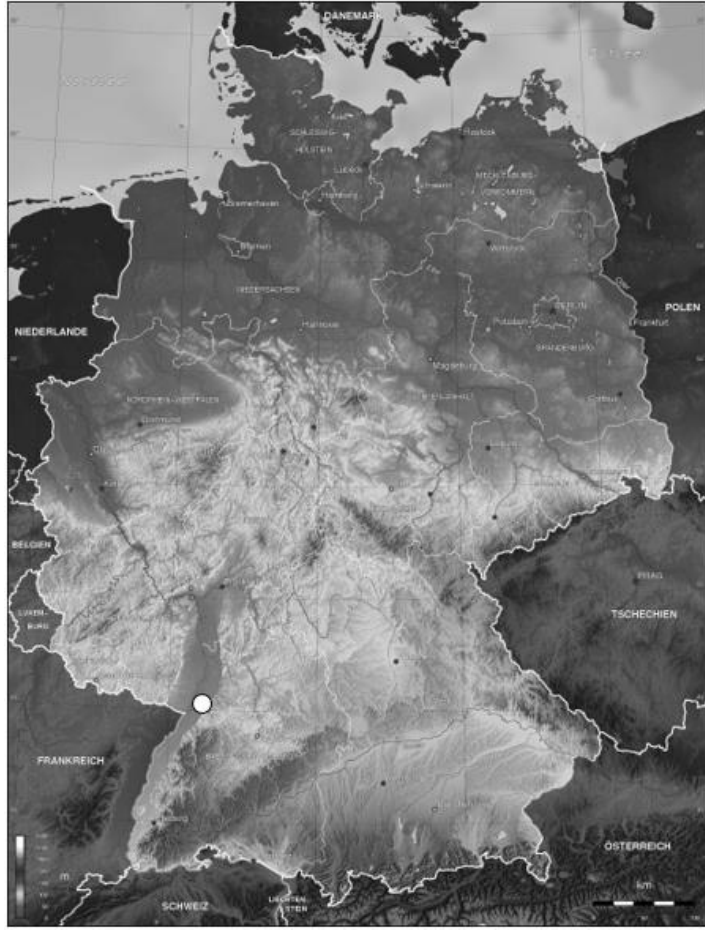

Map 3-1: Map of Germany, location of construction project highlighted with dot. Modified from [30]

5 District Administration

6 Country Road 
The road in question is located between Friedrichstal, a district of the town Stutensee and Graben, a district of the municipality Graben-Neudorf as can be seen on Map 3-2. Friedrichstal has a population of about 5,600 citizens and Graben-Neudorf of about 11,700 as of 2016 [30, 31]. After the extension of the Bundestraße ${ }^{7}$ B 36 in 2016 to a bypass road near Graben-Neudorf the Kreisstraße ${ }^{8}$ L 560 has been downgraded to the district road K 3533 and in the course of that process it has been decided to rehabilitate the section considered in this thesis. [32]

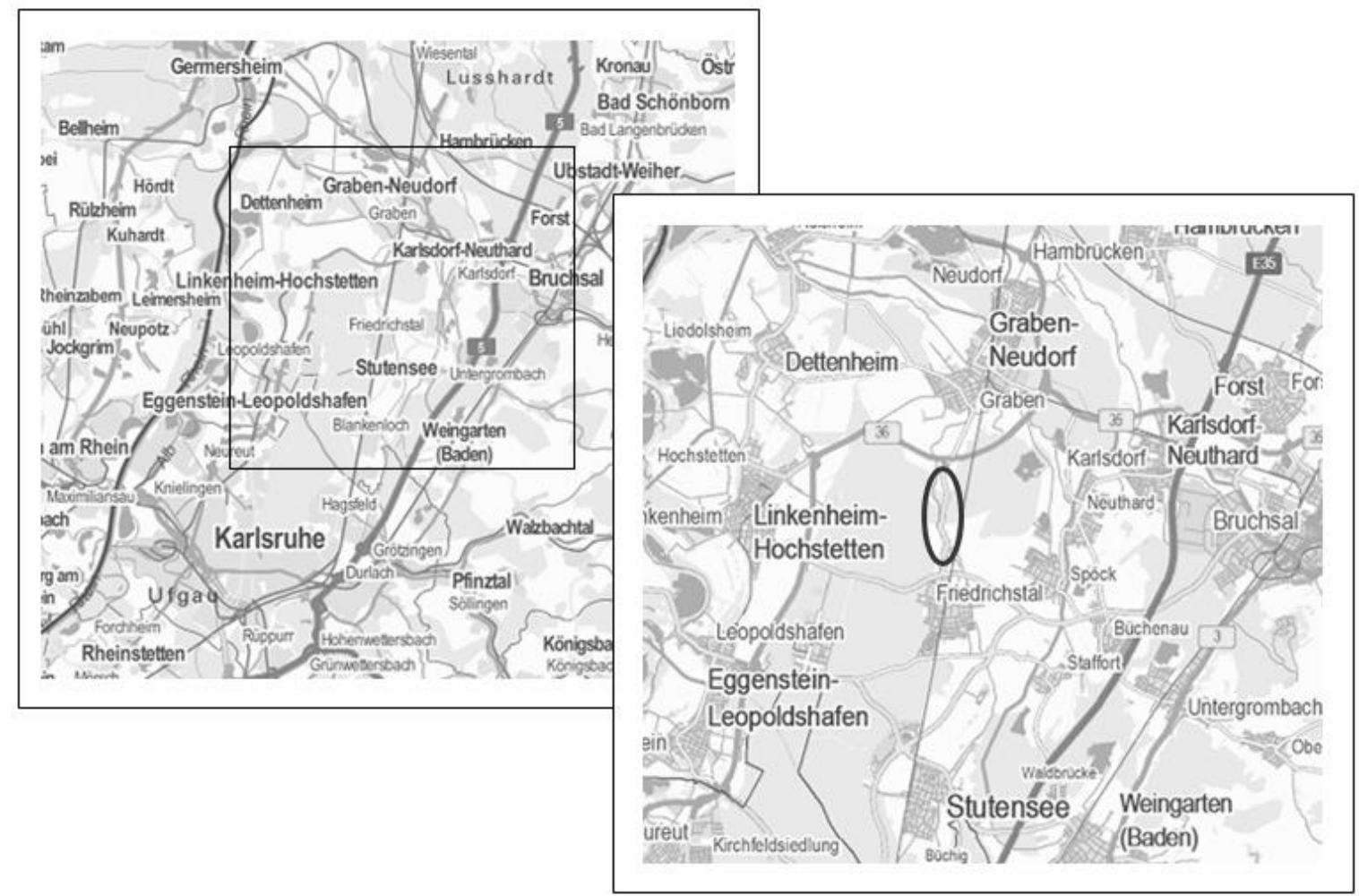

Map 3-2: Map with location of construction project [33]

7 National Highway

8 District Road 
The road section considered here has a length of about $2.5 \mathrm{~km}$ and prior to the construction works a width of 5.20 to $6.50 \mathrm{~m}$, the road has been in a poor condition, illustrated by Figure 3-2. The asphalt layers have been ranging from 3 to $12 \mathrm{~cm}$ and contained about 2,000-5,000 mg/kg so called $\mathrm{PAH}$, Polycyclic Aromatic Hydrocarbons. PAH are demonstrably carcinogenic and classified as harmful from $200 \mathrm{mg} / \mathrm{kg}$. Bitumen is generally said to contain $2.5-100 \mathrm{mg} / \mathrm{kg}$, however, tar contains up to $10^{4}$ as much PAH as bitumen. Tar has been used as paving material in Germany up until 1980 and has sometimes

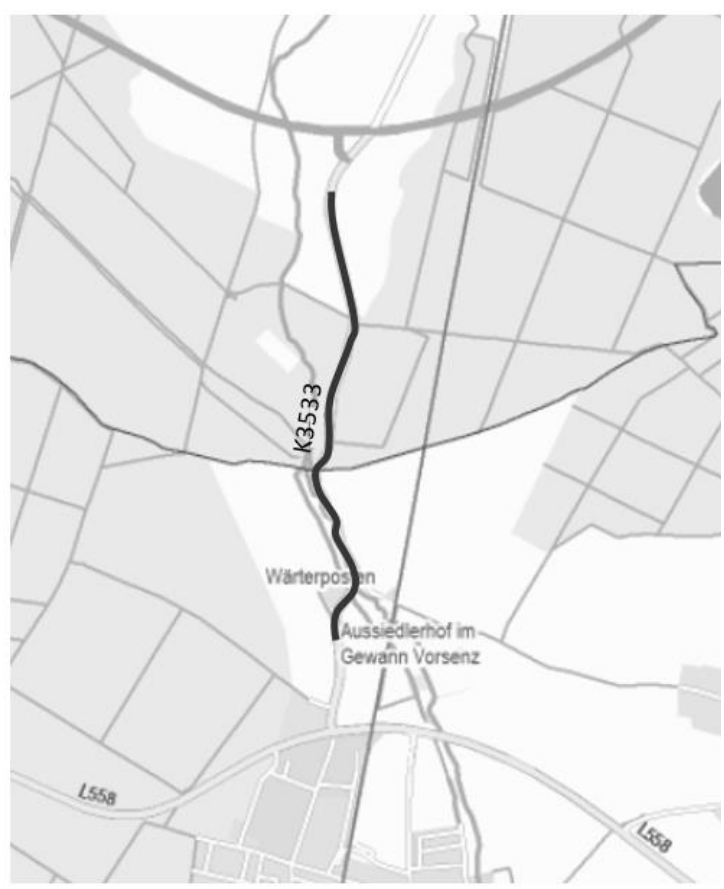

Map 3-3: Map with road section in question $(1: 20$ 000) [24] been just covered with asphalt thereafter. Therefore, the asphalt layers have been removed and disposed completely including a small layer of the sub base. [34]

The new road structure consists of a $4 \mathrm{~cm}$ surface layer of AC 11 D $\mathrm{S}$ asphalt (asphalt concrete surface layer with a maximum aggregate of $11 \mathrm{~mm}$ ), $14 \mathrm{~cm}$ asphalt base layer of AC $32 \mathrm{~T} \mathrm{~S}$ (asphalt concrete base layer with a maximum aggregate of $32 \mathrm{~mm}$ ) and a granular base layer of frost susceptible soil with a thickness of up to $20 \mathrm{~cm}$ to compensate for height differences in the existing granular base layer. The width of the new road is $6.0 \mathrm{~m}$ with shoulder of $1.5 \mathrm{~m}$ in accordance with the German standard for Country Roads, RAL 12 Figure 3-1: Illustrative Cross [29], as can be seen in Figure 3-1.

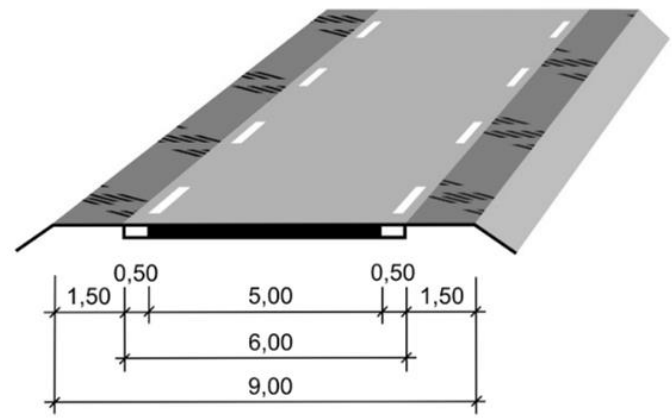
section of K3533 [29] 


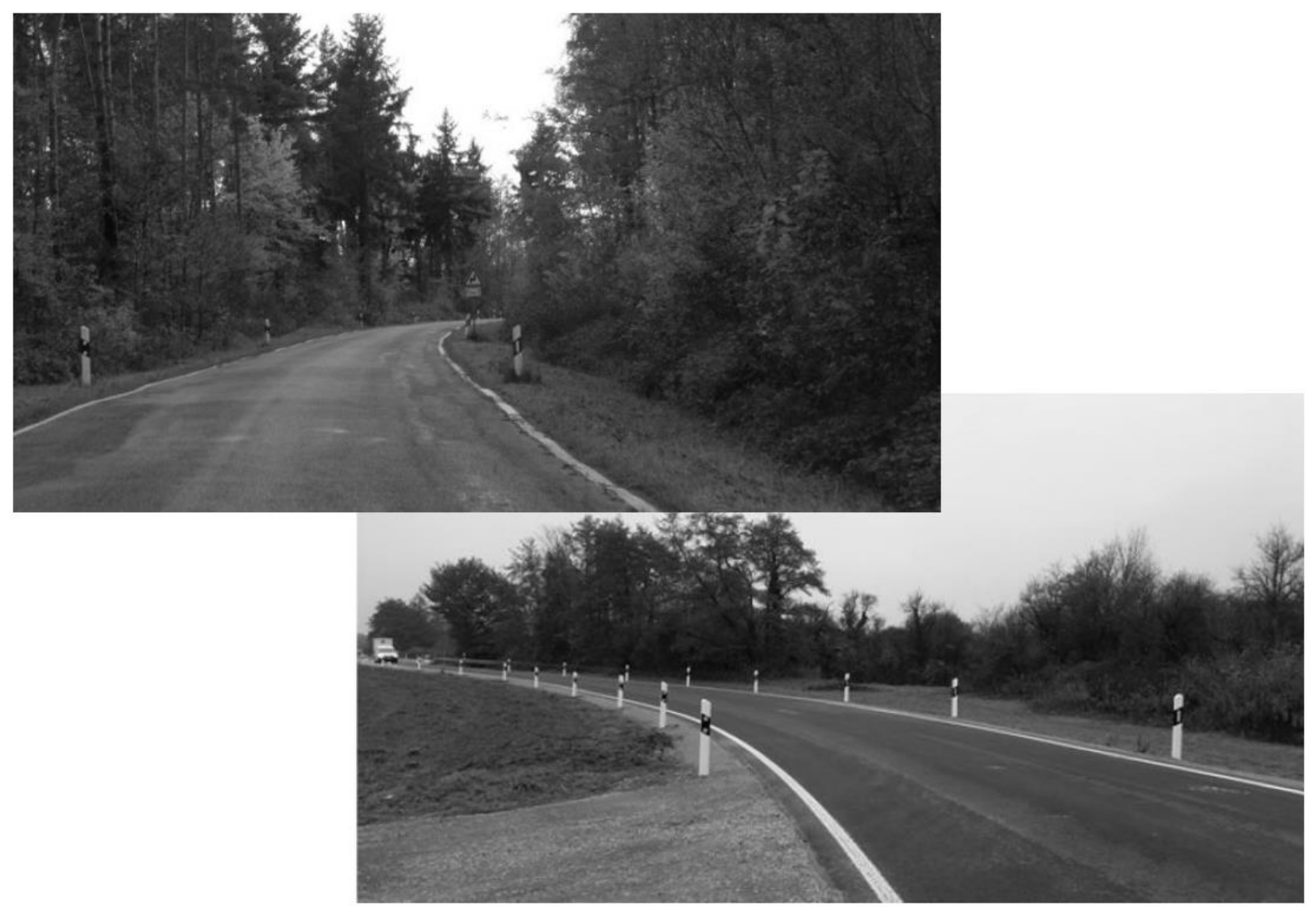

Figure 3-2: 63533 prior (top) and after (bottom) rehabilitation [32, 35] 


\subsection{Data collection}

The Landratsamt Karlsruhe gave access to the construction file including delivery notes, site journal, and asphalt test reports. The construction file has been reviewed and relevant data extracted. And summarized in this section.

\subsubsection{Materials}

The quantities of the delivery notes and the number of trips have been determined for each material and summarized in Table 3-1. For the granular base layer two types of material have been delivered, the majority has been material with a maximum aggregate of $45 \mathrm{~mm}$, additional material that has been delivered had a maximum aggregate of $32 \mathrm{~mm}$. Material for the surface layer has been sourced from one asphalt plant, the asphalt base layer has been sourced from two different plant, for this Master Thesis they have been joint together and considered as one. The Granular Base Layer has been provided from one plant.

Table 3-1: Summary of materials used for the rehabilitation of $K 3533$

\begin{tabular}{|c|c|c|}
\hline Material & Quantity [to] & \# of trips \\
\hline \multicolumn{3}{|l|}{ Surface Layer } \\
\hline AC 11 DS MOR 25/55-55 A TL Asphalt & $1,549.80$ & 59 \\
\hline \multicolumn{3}{|l|}{ Asphalt Base Layer } \\
\hline AC 32 TS KA 50/70 TL Asphalt & $3,253.73$ & 118 \\
\hline \multicolumn{3}{|l|}{ Granular Base Layer } \\
\hline KG 100 FSS 0-45 mm UF 3 TL G SoB / TL SoB-StB & $1,887.60$ & 66 \\
\hline KG 100 FSS/STS $0-32 \mathrm{~mm} * * *$ TL G SoB-StB & 697.20 & 25 \\
\hline \multicolumn{3}{|l|}{ Removed Material } \\
\hline 43 S Asphalt containing tar & $2,763.13$ & 97 \\
\hline
\end{tabular}


3.2.2 Equipment

A list of the equipment used has been taken from the site journal. To determine possible types of the machines data from the Baugeräteliste (BGL) 2015 [36], a list of key figures of various construction machines and equipment, has been taken. No exact information about the machines has been available in the site journal. The equipment determined for the project and the approximate energy consumption from the BGL has been listed below:

- Excavator

- Truck

- Wheel loader

- Transporter

- Roller

- Tandem roller

- Combination roller

- Semitrailer

- Asphalt paver

- Mobile excavator $\rightarrow 60 \mathrm{~kW} / \mathrm{h}$

$\rightarrow 300 \mathrm{~kW} / \mathrm{h}$

$\rightarrow 50 \mathrm{~kW} / \mathrm{h}$

$\rightarrow 75 \mathrm{~kW} / \mathrm{h}$

$\rightarrow 13 \mathrm{~kW} / \mathrm{h}$

$\rightarrow 48 \mathrm{~kW} / \mathrm{h}$

$\rightarrow 300 \mathrm{~kW} / \mathrm{h}$

$\rightarrow 7 \mathrm{~kW} / \mathrm{h}$

$\rightarrow 100 \mathrm{~kW} / \mathrm{h}$ 


\section{$4 \quad$ Standards/ Guidelines}

The assessment tools considered in this thesis are based on various different guidelines and standards developed for the planning stages and aspects of the construction process the tool is concerned about. The following section is introducing the guidelines and standards relevant within the scope of this thesis with regard to their content and scope.

The growing awareness of the importance of conscious and sustainable development in the construction sector has led to the demand for regulating standards and guidelines. Especially the assessment of the performance of construction products and works has been subject of these publications. However, so far the focus has been on the assessment of buildings products as can be seen in the list of available international ISO and European EN standards in the following tables (Table 4-2, Table 4-3). Yet the Swiss Society of Engineers and Architects and the Swiss Association of Road and Transportation Experts has published a number of guidelines giving a framework for the sustainability evaluation of infrastructure projects, a list of these guidelines can be seen in Table 4-1. The following section will give a brief introduction into the methods described in the ISO 14040 International Standards Series, the European Standard EN 15804, and the Swiss Standards SN 641800 and 641 810 .

Table 4-1: Overview of Swiss standards concerned with sustainability in the construction sector

\section{Roadways}

SIA 112/2, 2016 - Sustainable Construction - Civil Engineering and Infrastructure

SN 641800, 2008 - Sustainability Assessment of Road Infrastructure Projects SN 641810, 2014 - Sustainability Assessment of Road Infrastructure Projects Benefit-Analysis and Cost-Effectiveness-Analysis

SN 641820, 2006 - Cost-Benefit-Analysis in Traffic - Basic Standard 


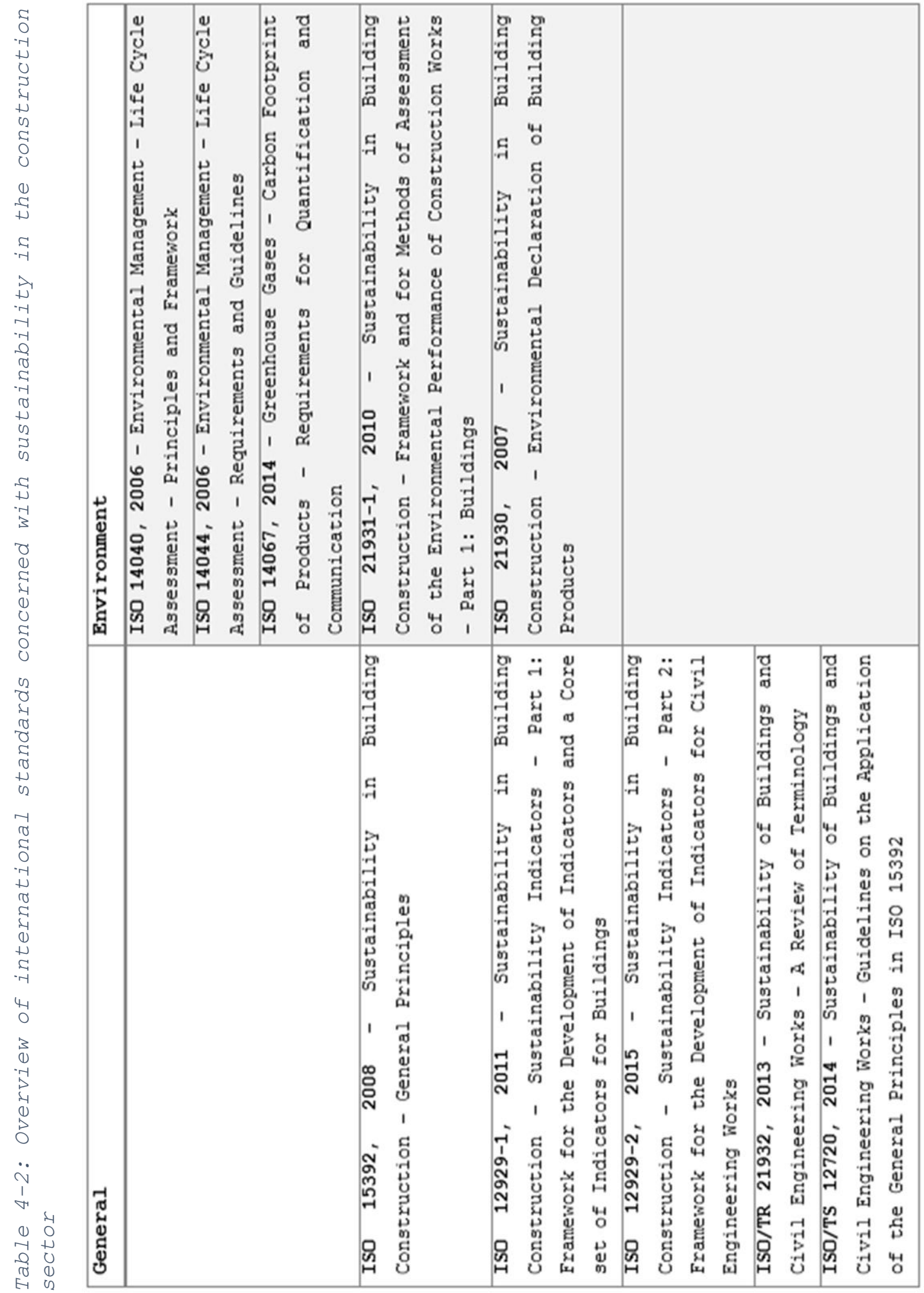




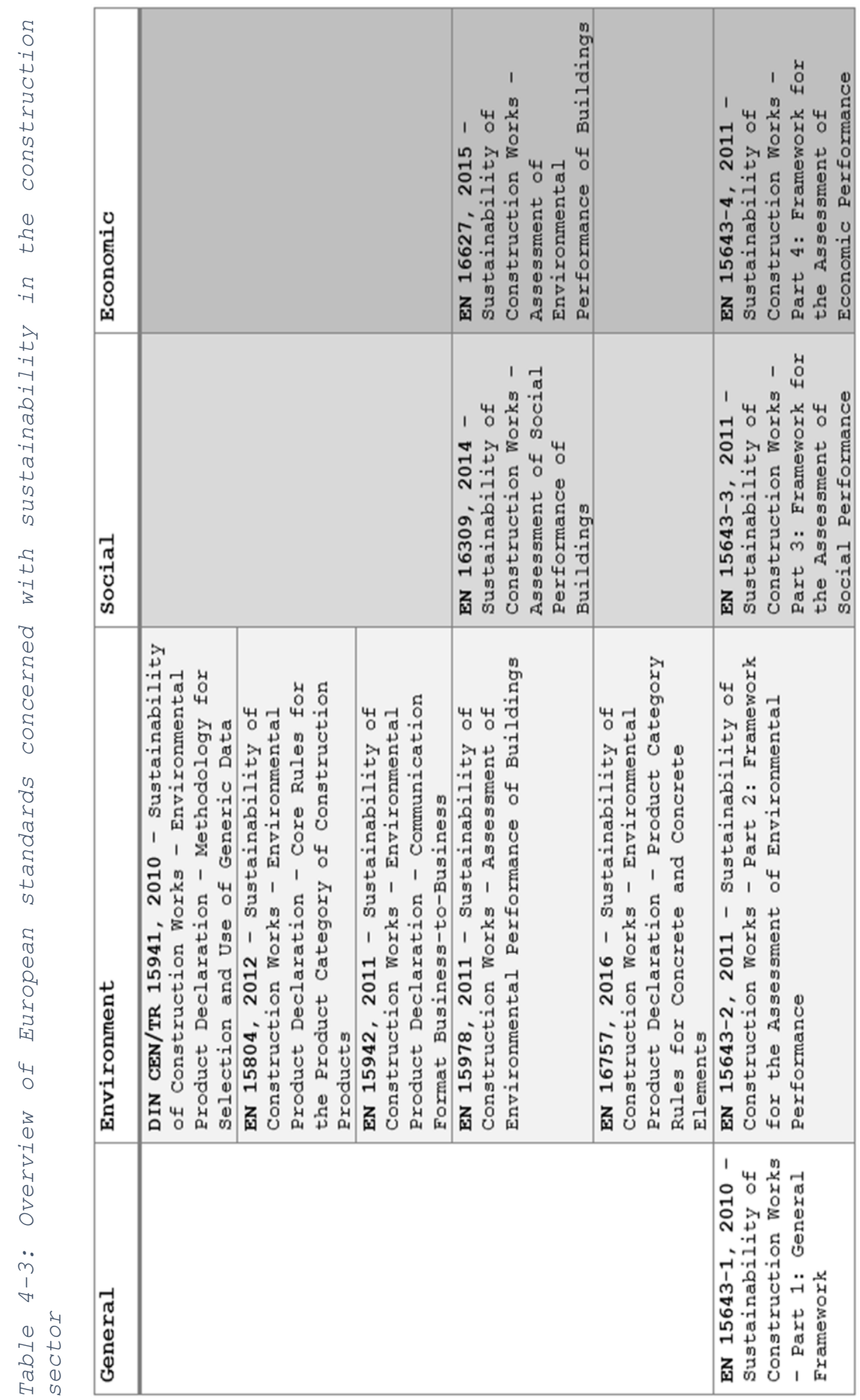




\subsection{ISO 14040 Series - Life Cycle Assessment}

Life Cycle Assessment (LCA) is one of the techniques that has been developed to allow a better understanding of the environmental impact of the production and application of products. LCA can help to detect ways to improve the environmental characteristics of a product in the different phases of its life cycle, inform decision-makers, select relevant indicators and suitable measures for these as well as award ecolabels. The scope of an LCA are environmental aspects and potential impacts of a product over its whole life, 'from cradle to grave', it generally does not consider social or economic aspects. An LCA is comprised of four phases:

(1) The goal and scope definition phase

(2) The inventory analysis phase

(3) The impact assessment phase

(4) The interpretation phase

Other environmental management techniques are for example risk assessment or environmental auditing. It depends on the individual situation which techniques is most appropriate. The international standards ISO 14040 and ISO 14044 address two types of life cycle analysis, life cycle assessment studies and life cycle inventory studies.[37]

The scope of the ISO 14040 standard is as follows: [37]

- The goal and scope definition of an LCA

- The life cycle inventory analysis (LCI) phase

- The life cycle impact assessment (LCIA) phase

- The life cycle interpretation phase

- Reporting and critical review of an LCA

- Limitations of an LCA

- Relationship between the LCA phases 
An LCA considers according to ISO 14040 as mentioned earlier the entire life of a product, from the raw material extraction and acquisition, the energy and material production and manufacturing to the use, maintenance, and end of life treatment. The concept of LCA is based on a functional unit defining what is being studied. The functional unit is the foundation of an LCA and influences all subsequent analyses as well as all inputs, outputs and the LCIA profile. The assessment tools considered in this thesis for instance are based on the functional unit of a three dimensional road section. [37]

The ISO 14044 standard is giving additional guidelines for the application of an LCA. The following list is illustrating the scope of the standard:

- The goal and scope definition of the LCA

- The life cycle inventory analysis phase

- The life cycle impact assessment phase

- The life cycle interpretation phase

- Reporting and critical review of the LCA

- Limitations of LCA

- Relationship between the LCA phases

- Condition for use of value choices and optional elements

The standard also includes instructions about the methodology for the application of an LCA in more detail. All four phases of the LCA are considered separately including examples of applications, data collection sheets and check lists. The steps of each phase are depicted in flow charts illustrating the scope of each phase and helping to structure the application of an LCA. [38]

Both international standards, ISO 14040 and 14044 are fundamental guidelines for the environmental assessment of construction products and practices. Each of the assessment tools applied here are based in some way on the ISO 14040 Series. 


\subsection{EN 15804 - Environmental Product Declaration}

The European Standard EN 15804:2012+A1:2013 [39] about Environmental Product Declarations (EPD) is aiming to standardise EPDs for construction products and practices. The life-cycle stages of the product considered here follow the structure depicted in the European Standard EN 15643-2 [40] (see Figure 5-1 in Section 5.1). EN 15804 lists the following 24 indicators as mandatory for comprehensive EDPs divided into four categories: environmental impact, resources, waste category and output flow:

Environmental impact indicators:

(1) Global Warming Potential (GWP)

(2) Ozone Depletion Potential (ODP)

(3) Acidification potential (AP)

(4) Eutrophication potential (EP)

(5) Formation potential of tropospheric ozone (POCP)

(6) Abiotic depletion potential for non-fossil resources (ADPelements)

(7) Abiotic depletion potential for fossil resources (ADP-fossil fuels)

Resource use indicators:

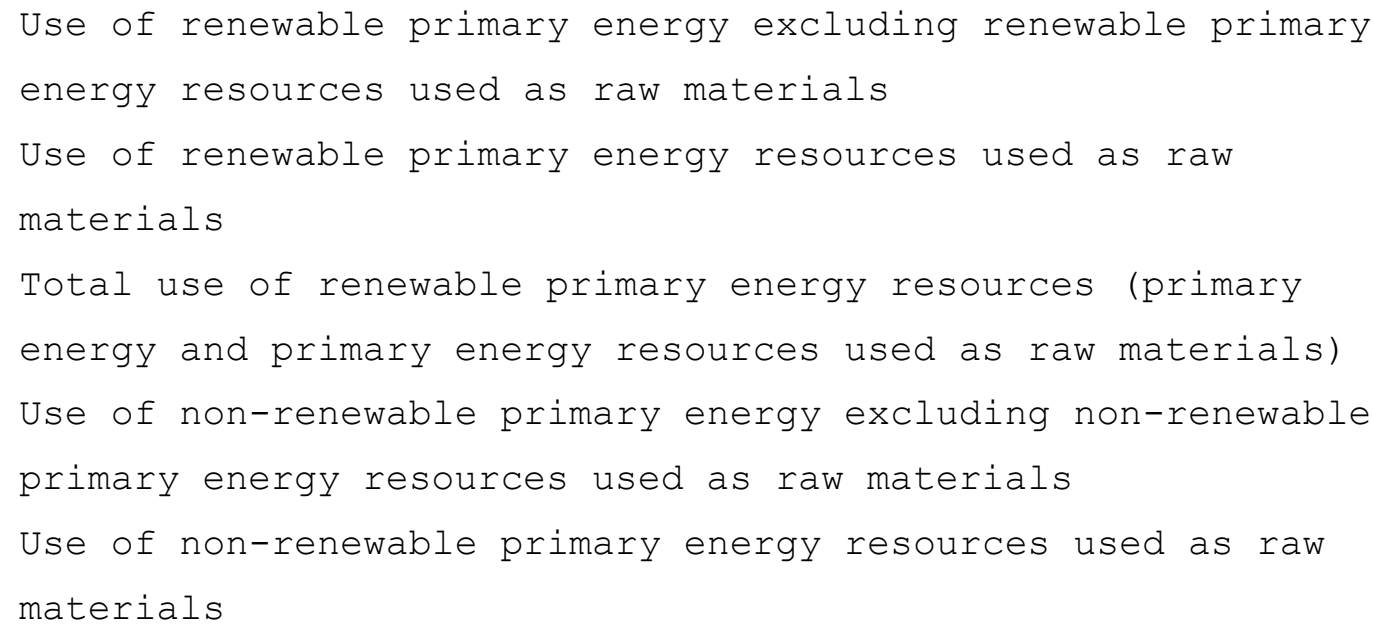


(13) Total use of non-renewable primary energy resources (primary energy and primary energy resources used as raw materials)

(14) Use of secondary material

(15) Use of renewable secondary fuels

(16) Use of non-renewable secondary fuels

(17) Use of net fresh water.

Waste category indicators:

(18) Hazardous waste disposed

(19) Non-hazardous waste disposed

(20) Radioactive waste disposed.

Output flow indicators:

(21) Components for re-use

(22) Materials for recycling

(23) Materials for energy recovery

(24) Exported energy

These indicators are solely considering environmental aspects of the products life-cycle and for a comprehensive sustainability evaluation social and economic indicators have to be added to this list. EN 15804 has often been quoted by assessment tools such as Athena Pavement LCA and publications and projects with lists of sustainability assessment indicators such as the EU project EDGAR [41].

\subsection{Swiss Guidelines for Sustainability Evaluation of Road Infrastructures SN $641800 /$ SN 641810}

The scope of the Swiss guideline SN 641800 for the sustainability assessment of roadway infrastructure projects is for all stages of the planning and construction process, with emphasis on the ex-ante (beforehand) evaluation, as opposed to the ex-post (subsequent) evaluation, of a project. The guideline is specifying target systems for the sustainability evaluation and introducing evaluation methods and 
their scope of application. The purpose of the guideline is to define the goals to be examined and is intended to be a basis for the sustainability evaluation of infrastructure projects of the transportation sector. The aim is to provide decision-makers with qualitative and quantitative advantages and disadvantages of a project and to enable an evaluation of possible options in terms of their sustainable development. The consideration of the sustainable impact of the different options in the variant analysis would allow sustainability considerations to influence the bidding process in spite of the German regulation to award the project to the lowest bidder. [42]

SN 641800 is defining the fundamental principles of sustainability as the need to assume the responsibility of the future by quoting the Bruntland definition of sustainability as mentioned in section 2.2.1. The guideline further states that society, economy and environment have to be taken into account in equal measures in the weighting process in a transparent way. [42]

The Swiss Federal Department of the Environment, Transport, Energy and Communications published a list of indicators for a target system for sustainable traffic with overall goals and sub goals. The target system shown in Appendix A can be used as whole or in parts depending on the scale of the project to be evaluated to ensure that all relevant sustainability aspects are considered. [42-44]

The Swiss target system is dividing each sustainability pillar into three main goals and an overall number of 25 sub-goals. The target system catalogue is the foundation of each sustainability assessment. Based on the selected list of relevant goals a justified evaluation has to be made. [43]

The method of evaluation has to be adopted to the scope and state of the project and each option should be compared in relation to the reference case, the present situation without changes. The following different 
methods are described briefly in the SN 641800 guideline: impact analysis, comparative value analysis, benefit analysis, cost-effectiveness analysis, cost-benefit analysis, and extended cost-benefit analysis.

In a cost-benefit analysis the aim is to monetise all impacts associated with the project, this means indicators which cannot be monetised cannot be taken into account. Thus in an extended cost-benefit-analysis these latter indicators are included either in a descriptive way or with a grading scheme. An extended cost-benefit analysis is comprised of three partial analyses, one part is a cost-benefit analysis evaluating all indicators that can be monetised, one part is an analysis evaluating all indicators that cannot be monetised assigning social, economic, and environmental points respectively. The third part consists of additional descriptive indicators.

This so called NISTRA-Method is an evaluation method using the sustainability indicators mentioned earlier. NISTRA and the accompanying Microsoft Excel Tool eNISTRA have been developed by the Swiss Federal Roads Office (FEDRO) using the Guideline SN 641820 as a basis. NISTRA will be described in more detail in section 6.1. [42]

The Swiss standard SN 641810 is, similar to the ISO 14044 standard in relation to ISO 14040, a guideline for the application of two methods described in SN 641 800. This standard is providing templates for the application of a benefit-analysis and a cost-effectiveness-analysis including examples and explanations of different indicators considered. [45] 


\section{$5 \quad$ Databases}

There are numerous databases available for emissions associated with the production, installation and end-of-life treatment of construction products. This section will introduce some of these databases and compare selected values.

\section{1 ÖKOBAUDAT (D)}

The Federal Ministry for the Environment, Nature Conservation, Building and Nuclear Safety of Germany is operating the online database ÖKOBAUDAT since $1^{\text {st }}$ September 2014. Data gathered for the database is in compliance with the European standard EN 15804 [39]. [46]

The following categories of materials are available:

(1) Mineral building materials

(2) Insulation materials

(3) Wood

(4) Metals

(5) Coverings

(6) Plastics

(7) Components for windows and curtain walls

(8) Building service engineering

(9) Others 


\begin{tabular}{|c|c|c|c|c|c|c|c|c|c|c|c|c|c|}
\hline \multicolumn{3}{|c|}{ A $1-3$} & \multicolumn{2}{|c|}{ A $4-5$} & \multicolumn{5}{|c|}{ B $1-7$} & \multicolumn{4}{|c|}{ C $1-4$} \\
\hline \multicolumn{3}{|c|}{ PRODUCT STAGE } & \multicolumn{2}{|c|}{ CONSTRUCTION PROCESS } & \multicolumn{5}{|c|}{ USE STAGE } & \multicolumn{4}{|c|}{ END OF LIFE } \\
\hline A1 & A2 & A3 & A4 & A5 & B1 & B2 & B3 & B4 & B5 & $\mathrm{C} 1$ & $\mathrm{C} 2$ & C3 & $\mathrm{C} 4$ \\
\hline \multirow[t]{3}{*}{ 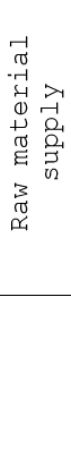 } & 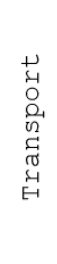 & 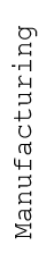 & 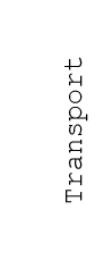 & 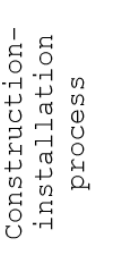 & $\begin{array}{l}0 \\
0 \\
0 \\
D\end{array}$ & 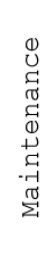 & $\begin{array}{c}4 \\
-7 \\
\sigma \\
\propto \\
0 \\
0 \\
\sim 1\end{array}$ & 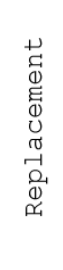 & 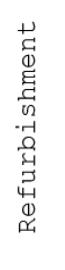 & 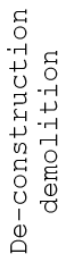 & 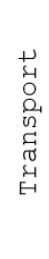 & $\begin{array}{l}0 \\
.1 \\
-1 \\
0 \\
0 \\
0 \\
0 \\
0 \\
0 \\
01 \\
0 \\
0 \\
0 \\
1 \\
0 \\
0 \\
0 \\
3\end{array}$ & $\begin{array}{l}7 \\
\pi \\
02 \\
0 \\
0 \\
01 \\
01 \\
-11 \\
0\end{array}$ \\
\hline & & & & & B 6 & \multicolumn{4}{|c|}{ Operational energy use } & & & & \\
\hline & & & & & B 7 & & catio & wat & use & & & & \\
\hline
\end{tabular}

Figure 5-1: Life-cycle stages EN 15643-2 [40]

In compliance with EN 15804 the data is structured in the life-cycle stages depicted in Figure 5-1. In addition to specific values a description of the process that has been considered when determining the specific values for each material is included in the database. ÖKOBAUDAT is primarily focused on materials used in the structural construction sector, however some types of asphalt are available in the database. [47] For Splittmastixasphalt for example ÖKOBAUDAT lists among others the following emissions for $1 \mathrm{~kg}$ of material:

- Renewable primary energy:

$$
\begin{array}{lll}
\text { - Production (A1-A3) : } & 0.05477 \mathrm{MJ} \\
\text { - Installation (A5) : } & 0.0008873 \mathrm{MJ}
\end{array}
$$

- Non-renewable primary energy:

- Production (A1-A3) : $4.11 \mathrm{MJ}$

- Installation (A5): $0.01163 \mathrm{MJ}$

- Global Warming Potential:

- Production (A1-A3): $0.07861 \mathrm{kgCO}_{2} \mathrm{e}$

- Installation (A5) : $0.0008416 \mathrm{kgCO}_{2} \mathrm{e}$ 


\subsection{Defra's Conversion Factors (UK)}

Defra's GHG Conversion Factors are compiled in a number of spread sheets and are updated every year. These factors are, among others for the conversion of energy sources in different units into various types of emissions. For example, 1,000 kWh generated using diesel equals about $246 \mathrm{~kg} \mathrm{CO}_{2} \mathrm{e}$ according to Table 5-1.

Another example are conversion factors for emissions of produced materials. The production of 1,000 to asphalt sourced as re-used material equals $1,700 \mathrm{~kg} \mathrm{CO} \mathrm{CO}_{2}$ (Table 5-2). This values are significantly higher than the $78.6 \mathrm{~kg} \mathrm{CO}$ e for the production of one tonne asphalt according to ÖKOBAUDAT. The differences might be due to local conditions or the methodology used when compiling the databases.

The list of conversion factors has been published for companies to use when reporting their emissions in accordance with the Companies Act 2006 (Strategic Report and Directors' Report) Regulations 2013. The Companies Act 2006 requires that quoted companies in the UK report the emissions they are responsible for. [48]

Table 5-1: Example of conversion factors for diesel [38]

\begin{tabular}{|c|c|c|c|c|c|}
\hline Fuel & Unit & $\mathrm{kg} \mathrm{CO}{ }_{2} \mathrm{e}$ & $\mathrm{kg} \mathrm{CO}{ }_{2}$ & $\mathrm{~kg} \mathrm{CH} \mathrm{CH}_{4}$ & $\mathrm{~kg} \mathrm{~N} \mathrm{~N}_{2} \mathrm{O}$ \\
\hline \multicolumn{6}{|c|}{ 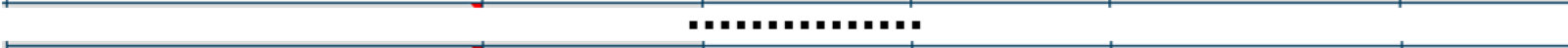 } \\
\hline \multirow{4}{*}{ Diesel (average biofuel blend) } & tonnes & 3108,52039 & 3082,82224 & 0,71415 & 24,98400 \\
\hline & litres & 2,61163 & 2,59007 & 0,00060 & 0,02096 \\
\hline & kWh (Net CV) & 0.26161 & 0.25946 & 0.00006 & 0.00210 \\
\hline & kWh (Gross CV) & 0,24592 & 0,24389 & 0,00006 & 0,00197 \\
\hline
\end{tabular}


Table 5-2: Example of CO2e emissions of construction materials [38]

\begin{tabular}{|c|c|c|c|c|c|}
\hline & & Primary material production & Re-used & Open-loop source & Closed-loop source \\
\hline Material & Unit & $\mathrm{kgCO} \mathrm{CO}_{2}$ & $\mathrm{kgCO} \mathrm{CO}_{2} \mathrm{e}$ & $\mathrm{kg} \mathrm{CO} \mathrm{CO}_{2}$ & $\mathrm{~kg} \mathrm{CO} \mathrm{CO}_{2}$ \\
\hline Aggregates & tonnes & 11,0 & 2,0 & 4,0 & 3,0 \\
\hline Average construction & tonnes & 74,0 & & 2,0 & \\
\hline Asbestos & tonnes & 27,0 & & & \\
\hline Asphalt & tonnes & 39,2 & 1,7 & & 28,0 \\
\hline Bricks & tonnes & 244,8 & & 3,0 & \\
\hline Concrete & tonnes & 134,8 & & 3,0 & 3,0 \\
\hline Insulation & tonnes & 1864,8 & & & 1854,0 \\
\hline Metals & tonnes & 4768,9 & & & 865,0 \\
\hline Soils & tonnes & & & & 1,5 \\
\hline Mineral oil & tonnes & 1401,0 & & & 655,0 \\
\hline Plasterboard & tonnes & 120,1 & & & 32,0 \\
\hline Tyres & tonnes & 3410,0 & 489,0 & 2,0 & 0,0 \\
\hline Wood & tonnes & 435,0 & 46,0 & 260,0 & 95,0 \\
\hline
\end{tabular}

\subsection{Athena (CA)}

In the Athena Life Cycle Inventory database information about materials, products as well as energy use, transportation and construction and demolition processes are considered. The data available is sensitive to the location of the construction site which is why the region of the project is needed as input for the Athena Pavement LCA. The Athena data has been designed to be used in combination with its assessment tools and are therefore not available to be viewed by the user. However, Athena provides reports regarding the data to provide transparency about the workings of the assessment tools. The data representing national or industry averages has been compiled in accordance with the international standards ISO 14040 and ISO 14044. [49] 


\section{Assessment Tools}

Future-oriented development consists of more than ecological, resourcefriendly and energy efficient constructing. Other aspects such as aesthetics, integrated planning and functional and technical qualities are also important. Therefore, sustainable development is not possible with strict principles and regulations but needs individual solutions adapted to each project and its framework. Different countries chose different concepts and approaches to promote sustainable development, Germany and Austria for example chose a cause-oriented approach by implementing the Energieeinsparverordnung ${ }^{9}$ and supporting the construction of low-energy buildings and passive-houses.

A big step in the sustainability evaluation has been the development and implementation of labels and certificates. Labels and certificates enable a comprehensive assessment of a product or project as an entire system as well as a summarizing of existing planning tools and sub criteria such as energy efficiency or life cycle assessment. They are based on existing national standards and regulations and enable a project assessment in early stages of the planning process and therefor an adjustment to sustainability goals over the whole process. Certificates and labels are, after the completion of the construction process a transparent proof of quality and support constant quality control. [50]

9 Energy Saving Act 
Most assessment tools have been developed with regard of the demands of individual nations. The following list gives some examples of sustainability assessment tools and labels for buildings in different countries:

- Germany: DGNB (2008)

- France: HQE (1996)

- Switzerland: MINERGIE (1994)

- United Kingdom: BREEAM (1990)

- United States of America: LEED (1994)

The last two, BREEAM and LEED are the two biggest certification tools worldwide with BREEAM having 552,600 certified and 2,254,200 registered buildings in 77 countries and LEED having 79,000 participating projects across 160 countries in 2016 [51, 52]. BREEM has developed individual catalogues for different countries to allow for buildings outside the UK to be certified according to the local conditions based on these international systems such as BREEAM France. Contrary to that LEED has on the one hand used their standards and criteria developed for the conditions of the Northern American continent to certify buildings on an international level and on the other hand developed individual subsidiary systems based on the original American concept such as LEED Brazil. Cooperations between Germany and other countries such as China have been made for the German system DGNB to be applied there. [50]

Internationally a number of organisations and cooperations recognized sustainable construction as an important goal or have been formed to promote sustainability in the construction sector such as the international umbrella organisation World Green Building Council (World GBC). One of the worldwide most important conferences about sustainable construction is the World Sustainable Building Conference. The International Initiative for a Sustainable Build Environment (iiSBE) has the goal to develop a uniform comparable assessment tool. They are promoting the comparability of the sustainability quality of buildings 
on an international scale. iisBE developed in 1996 the sBtool which is today still tested in various case studies, it is using a different methodology than BREEAM and LEED, SBtool has a general assessment matrix as a basis for the adaptation to national conditions to allow an international comparison between buildings. This ambitious approach failed because after the adaptation of the initial matrix to national conditions the results were no longer comparable. [50]

As has been already mentioned, over the last years a number of assessment tools have been developed and customized to the climatic, cultural and legal framework of individual nations. Further differences between individual tools are for example whether they evaluate whole constructions or specific products, whether they consider the ecological, economical, or social aspect or the whole sustainability performance. When developing and implementing an assessment tool it is crucial to formulate specific goals and key indicators to detect impacts and correlations between input variables. [50] 


\subsection{NISTRA}

The Swiss assessment method NISTRA (Nachhaltigkeitsindikatoren für Strasseninfrastrukturprojekte) and the accompanying excel tool eNISTRA for road infrastructure projects has been commissioned and developed by the Swiss Federal Office for Streets (ASTRA). NISTRA has been tested on major Swiss road construction projects since 2003 and a revised version has been published in 2006. In addition to the NISTRA method ASTRA has published a standard regarding the cost-benefit-analysis in traffic, SN $641820 \cdot[44]$

For the application of NISTRA the planning process of a project should be well advanced so that detailed information about the impacts of the project are available. NISTRA can be used for the comparison of different alignments with respect to their environmental, economic and social impact. It is based on a list of economic, ecologic and social indicators for sustainable traffic published by the Swiss Federal Department of the Environment, Transport, Energy and Communications [43]. The method is dividing these indicators into three groups: indicators that can be monetized, indicators that cannot be monetized but can be assessed using a grading scheme and indicators that should only be assessed verbally. Thus NISTRA is not condensing the result to one value but is generating a report with three partial results which can be used as a basis for decision makers. [44]

NISTRA is structured as an extended cost-benefit-analysis. In a costbenefit analysis the aim is to monetise all impacts associated with the project, this means indicators which cannot be monetised cannot be taken into account. Thus in an extended cost-benefit-analysis these latter indicators are included either in a descriptive way or with a grading scheme. An extended cost-benefit analysis is comprised of three partial analyses, one part is a cost-benefit analysis evaluating all indicators that can be monetised resulting in a so called cost-benefit ratio, one part is a partial benefit analysis evaluating all indicators that cannot 
be monetised assigning social, economic, and environmental points respectively. The third part consist of additional information, so called descriptive indicators. Figure 6-1 is illustrating the structure of the NISTRA assessment method [42, 44]

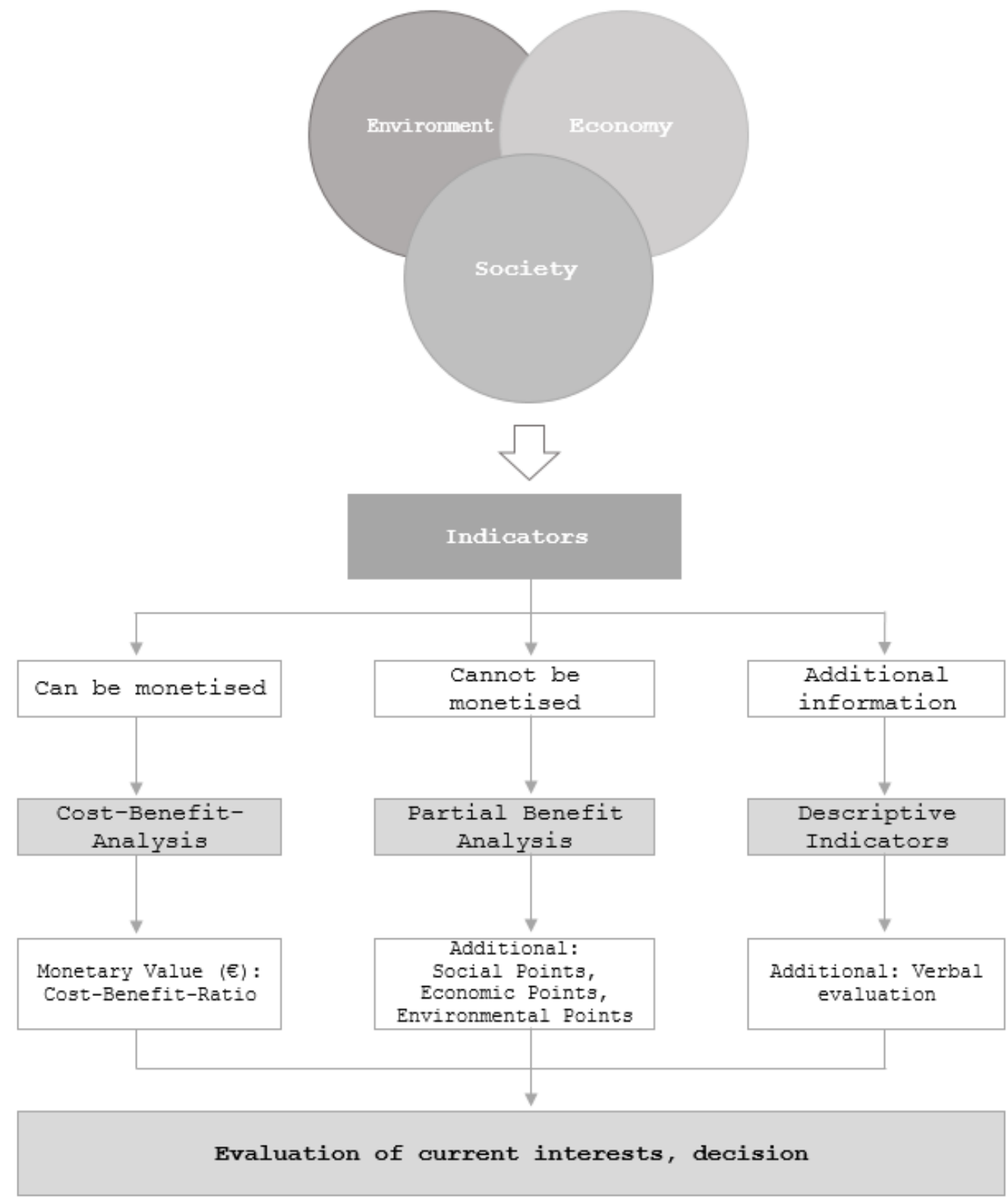

Figure 6-1: Principle of NISTRA [44] 
6.1 .1 Summary

NISTRA is generally assessing new construction projects by comparing different options and their impact on its surroundings. Thus the construction project used as an example for this thesis cannot be assessed by this method as it is a rehabilitation project of an already existing road. Therefor NISTRA will not be applied in the course of the thesis.

Even though, the concept of NISTRA is a comprehensive consideration of all three sustainability aspects: environment, social, economic. The division into three types of indicators allows the user of the method to evaluate each aspect individually and according to their own knowledge. However, this also has the potential for the result to be influenced by the opinions and views of the user and therefore the result may not be objective. Therefor the decision maker using the result should be aware of this possibility and interpret it accordingly.

For the application of the NISTRA method on a rehabilitation project the list of indicators should be adapted accordingly taking into consideration which aspects of the project can be influenced and what data is available when applying the method. 


\section{2 asPECT}

The British asphalt Pavement Embodied Carbon Tool (asPECT) is comprised of three parts, (1) the 'Protocol of the Calculation of Whole Life Cycle Greenhouse Gas Emissions Generated by Asphalt' [53], (2) a 'Further Guidance on the Calculation of Whole Life Cycle Greenhouse Gas Emissions Generated by Asphalt' [54] and (3) the software tool [55]. asPECT has been produced in 2008 by the Transportation Research Laboratory contracted by the Highway Agency, the Mineral Products Association and the Refined Bitumen Association, this collaboration is the so called Collaborative Research Program. The goal of the initial project was to determine the contribution of highway products and applications to climate change in a consistent approach. The scope of the asphalt life cycle of asPECT is comprised of ten steps as can be seen in Table 6-1. Operators can either consider all ten steps and thus the whole life cycle or only focus on assessing the asphalt from 'cradle-to-gate' or 'cradle-to-installation' i.e. steps 1-5 or 1-7 respectively. However, emissions generated by vehicles driving on the finished road are not included in the consideration as these are not under the influence of the road designers. [54]

asPECT is calculating the so called carbon dioxide equivalent ( $\left.\mathrm{CO}_{2} \mathrm{e}\right)$ emissions of an asphalt road in the functional unit $\mathrm{CO}_{2}$ e per tonne of asphalt per year. Through the use of $\mathrm{CO}_{2} \mathrm{e}$ it is taking into consideration that $\mathrm{CO}_{2}$ is not the only Greenhouse Gas (GHG) and enables a better comparison by converting other GHGs to $\mathrm{CO}_{2} \mathrm{e}$. For the conversion the mass of the emission is multiplied by its global warming potential. The global warming potential is measuring the energy consumed by the emissions of one tonne of a certain gas in relation to one tonne of $\mathrm{CO}_{2}$ over a certain period of time, generally 100 years [56]. 
Table 6-1: Steps of asphalt life cycle scope [54]

\begin{tabular}{|c|c|c|}
\hline \multicolumn{2}{|c|}{ Life-cycle stage } & \multirow{2}{*}{$\begin{array}{l}\text { Description } \\
\text { Acquiring raw materials from the } \\
\text { natural environment with the input of } \\
\text { energy }\end{array}$} \\
\hline 1 & Raw Material & \\
\hline 2 & $\begin{array}{l}\text { Raw Material } \\
\text { Transport }\end{array}$ & $\begin{array}{l}\text { Transporting acquired raw materials } \\
\text { to processing }\end{array}$ \\
\hline 3 & $\begin{array}{l}\text { Raw Material } \\
\text { Processing }\end{array}$ & $\begin{array}{l}\text { Crude oil refining, rock crushing and } \\
\text { grading, recycled and secondary } \\
\text { material processing }\end{array}$ \\
\hline 4 & $\begin{array}{l}\text { Processed } \\
\text { Material } \\
\text { Transport }\end{array}$ & $\begin{array}{l}\text { Transporting processed raw materials } \\
\text { to site of manufacture of bitumen } \\
\text { bound highway components }\end{array}$ \\
\hline 5 & $\begin{array}{l}\text { Road } \\
\text { Component } \\
\text { Production }\end{array}$ & Production of bitumen bound mixtures \\
\hline 6 & $\begin{array}{l}\text { Material } \\
\text { Transport to } \\
\text { Site }\end{array}$ & Delivery of materials to site \\
\hline 7 & Installation & $\begin{array}{l}\text { Placing material at the construction } \\
\text { site, mobilisation of plant and labor }\end{array}$ \\
\hline 8 & $\begin{array}{l}\text { Scheme } \\
\text { Specific } \\
\text { Works }\end{array}$ & $\begin{array}{l}\text { Installation of other specified } \\
\text { materials direct to site (e.g. } \\
\text { aggregates and geosystems) }\end{array}$ \\
\hline$\overline{9}$ & Maintenance & $\begin{array}{l}\text { Intervention to maintain the road: } \\
\text { overlay, surface dressing works, } \\
\text { patching, haunching etc. }\end{array}$ \\
\hline 10 & End of Life & $\begin{array}{l}\text { Excavation and material management, } \\
\text { mobilisation of plant and labour }\end{array}$ \\
\hline
\end{tabular}

The purpose of asPECT is to compare alternatives in the procurement stage in terms of the potential GHG emissions and the computation of GHG emissions during and after construction. It does not consider other sustainability aspects such as the social or economic impact of the construction project. [54] 
asPECT is mainly referring to three sources:

(1) PAS 2050: 2011 - Specification for the Assessment of the Life Cycle Greenhouse Gas Emissions of Goods and Services [57]

(2) Defra's Government GHG Conversion Factors for Company Reporting [58]

(3) ISO 14044 - Environmental Management - Life Cycle Assessment - Requirements and Guidelines [38]

PAS 2050 has been developed as a consistent method to assess the life cycle GHG emissions of goods and services for organizations. Allowing them to convey a better understanding of the emissions arising from their production process including the transportation, storage, production and disposing of their products as well as providing a standardized quantification of GHG emissions enabling the development and implementation of emission reduction programs. PAS is intended for organisations assessing the emissions of their products over the whole life cycle, from 'cradle-to-grave'. Due to the fact that PAS may need some adaptations to the requirements of the individual sector it is applied to, a list of specifications have been included. Supplementary requirements that might be applied to the individual situation have to meet these specifications. [57]

Defra's GHG Conversion Factors, which asPECT is based on, are described in more detail in section 5.2.

The accompanying software tool of asPECT has been developed using the necessary formulae, emissions factors and default data from the above mentioned documents to calculate the GHG emissions of asphalt products. The asPECT calculator software ${ }^{10}$ is available free of charge from the website sustainabilityofhighways.org.uk, it has four input screens:

10 Hereafter the use of the name asPECT will relate to the calculator software 
Materials, Plants, Projects, and Constants, the icons are depicted in Figure 6-2.

The materials screen includes a number of default materials according to the accompanying protocol and allows to create new materials either from product energy or from $\mathrm{CO}_{2}$ e figure. The plants screen gives an overview of all entered plants and allows to edit existing or create new plants. An overview of the details of all created projects is given in the projects screen, as well as the option to create a
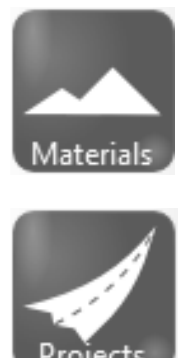

Projects

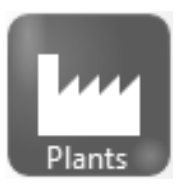

$\pi \Delta$

$\ominus \rho$

Constants

Figure 6-2: Toolbar icons [53]

new one. The fourth screen, the constants screen

consists of various editable forms where default constants can be adapted to each situation and project. A progress bar at the bottom of the main screen illustrates the progress of the data input. [54]

6.2.1 Application of asPECT

\section{a) Input}

\section{Materials}

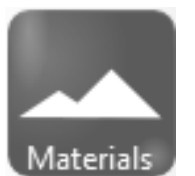

The first step when using the software tool is to input the materials needed for the asphalt mixture. The information needed are the distance from the supplier to the asphalt plant as well as the amount of emissions created by the quarrying of the materials in $\mathrm{kgCO}_{2} \mathrm{e} /$ to material. For the given road rehabilitation the distances have been determined using Google Maps, the emissions have been taken from the database ÖKOBAUDAT [47] and the Defra's GHG Conversion Factors [58]. Table 6-2 shows a summary of the input data for materials needed for the base layer as well as the surface layer. 
Table 6-2: Information needed for creation of materials used

\begin{tabular}{|c|c|c|c|}
\hline Material & Distance ${ }^{11}$ & $\mathrm{Kg} \mathrm{CO}_{2} \mathrm{e} / \mathrm{to}$ & Data Source \\
\hline \multicolumn{4}{|l|}{ AC 11 DS } \\
\hline Limestone (Filler) & $55 \mathrm{~km}$ & $33.8 \mathrm{~kg}$ & Ökobaudat \\
\hline Gravel $0 / 2$ & $35 \mathrm{~km}$ & $33.8 \mathrm{~kg}$ & Ökobaudat \\
\hline Moraine $0 / 2$ & $35 \mathrm{~km}$ & $33.8 \mathrm{~kg}$ & Ökobaudat \\
\hline Moraine 2/5 & $35 \mathrm{~km}$ & $33.8 \mathrm{~kg}$ & Ökobaudat \\
\hline Moraine $5 / 8$ & $35 \mathrm{~km}$ & $33.8 \mathrm{~kg}$ & Ökobaudat \\
\hline Moraine $8 / 11$ & $35 \mathrm{~km}$ & $33.8 \mathrm{~kg}$ & Ökobaudat \\
\hline Crushed Asphalt & $10 \mathrm{~km}$ & $1.7 \mathrm{~kg}$ & Defra's \\
\hline Bitumen & $8 \mathrm{~km}$ & $397.5 \mathrm{~kg}$ & Ökobaudat \\
\hline \multicolumn{4}{|l|}{$\mathrm{AC} 32 \mathrm{TS}$} \\
\hline Limestone (Filler) & $55 \mathrm{~km}$ & $33.8 \mathrm{~kg}$ & Ökobaudat \\
\hline Gravel $0 / 2$ & $35 \mathrm{~km}$ & $33.8 \mathrm{~kg}$ & Ökobaudat \\
\hline Moraine $2 / 5$ & $35 \mathrm{~km}$ & $33.8 \mathrm{~kg}$ & Ökobaudat \\
\hline Limestone $5 / 8$ & $75 \mathrm{~km}$ & $33.8 \mathrm{~kg}$ & Ökobaudat \\
\hline Limestone $8 / 16$ & $75 \mathrm{~km}$ & $33.8 \mathrm{~kg}$ & Ökobaudat \\
\hline Limestone 16/32 & $75 \mathrm{~km}$ & $33.8 \mathrm{~kg}$ & Ökobaudat \\
\hline Crushed Asphalt & $10 \mathrm{~km}$ & $1.7 \mathrm{~kg}$ & Defra's \\
\hline Bitumen & $8 \mathrm{~km}$ & $397.5 \mathrm{~kg}$ & Ökobaudat \\
\hline \multicolumn{4}{|l|}{ Additional Materials } \\
\hline Bitumen Emulsion & $10 \mathrm{~km}$ & $220.0 \mathrm{~kg}$ & asPECT \\
\hline FSS & $10 \mathrm{~km}$ & $33,8 \mathrm{~kg}$ & Ökobaudat \\
\hline
\end{tabular}

$\underline{\text { Plants }}$

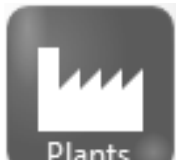

The second step is to input information about an asphalt plant based on its energy and fuel consumption and asphalt mixtures Plants produced by the plant. After contacting several asphalt plants and aggregate suppliers for the necessary data according to their reply approximate values have been chosen for the application of the software.

11 Distances estimated using https://wWw.google.de/maps/ 
Table 6-3 gives an overview of these input data for the creation of a plant. The asphalt mixtures that have been used for the project have been taken from the asphalt test reports that were part of the data supplied by the Landratsamt Karlsruhe and are depicted in Table 6-4.

Table 6-3: Information needed for creation of plant

\begin{tabular}{|l|l|l|}
\hline Information & Source & Amount \\
\hline Total annual production & & 160,000 to \\
\hline Electricity & Grid Electricity & $15,496,000.00 \mathrm{kWh}$ \\
\hline Fuel & Diesel & $16,000 \mathrm{l}$ \\
\hline Heating energy & natural gas (assumption) & $54,465,000.0 \mathrm{kWh}$ \\
\hline Mode of transport & & Rigid >17t \\
\hline
\end{tabular}

Table 6-4: Asphalt mix design

\begin{tabular}{|l|l|l|}
\hline Asphalt Type & Material & Amount M. - $\frac{0}{\circ}$ \\
\hline AC 11 DS & Limestone (Filler) & 4.0 \\
\cline { 2 - 3 } & Gravel 0/2 & 8.0 \\
\cline { 2 - 3 } & Moraine 0/2 & 24.0 \\
\hline & Moraine 2/5 & 10.0 \\
\cline { 2 - 3 } & Moraine 5/8 & 19.0 \\
\cline { 2 - 3 } & Moraine 8/11 & 20.0 \\
\hline & Crushed Asphalt & 15.0 \\
\hline & Bitumen & 6.1 \\
\hline \multirow{5}{*}{32 TS } & Limestone (Filler) & 4.5 \\
\cline { 2 - 3 } & Gravel 0/2 & 5.0 \\
\cline { 2 - 3 } & Moraine & 5.0 \\
\cline { 2 - 3 } & Limestone 5/8 & 4.5 \\
\hline & Limestone 8/16 & 6.0 \\
\hline & Limestone 16/32 & 15.0 \\
\cline { 2 - 3 } & Crushed Asphalt & 60.0 \\
\cline { 2 - 3 } & Bitumen & 4.0 \\
\hline
\end{tabular}


Projects

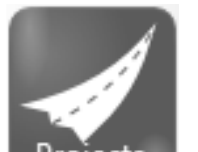

In a third step the project is created using the amounts of material according to the data from the Landratsamt Karlsruhe

Projects and making assumptions about the distances to and from the construction site. An overview of the input data can be seen in Table $6-5$.

Table 6-5: Input data to create new project

\begin{tabular}{|l|l|l|l|l|}
\hline Information & Distance & $\begin{array}{l}\text { Mode of } \\
\text { Transp. }\end{array}$ & Material & Amount \\
\hline $\begin{array}{l}\text { Material } \\
\text { transport to Site }\end{array}$ & $10 \mathrm{~km}$ & Rigid >17t & AC 11 DS & 1,549,73 to \\
\cline { 2 - 5 } & $10 \mathrm{~km}$ & Rigid >17t & AC 32 TS & $3,253.73$ to \\
\cline { 2 - 5 } & $10 \mathrm{~km}$ & Rigid >17t & Bitumen Emulsion & 4.05 to \\
\cline { 2 - 5 } & $10 \mathrm{~km}$ & Rigid >17t & $\begin{array}{l}\text { Frost susceptible } \\
\text { soil }\end{array}$ & $2,584.80$ to \\
\hline $\begin{array}{l}\text { Excavation } \\
\mathbf{2 . 2} \mathbf{m} \mathbf{2 0} \mathbf{m m}\end{array}$ & $10 \mathrm{~km}$ & Rigid >17t & $\begin{array}{l}\text { Excavation } \\
\text { (Landfilled) }\end{array}$ & 4803,53 to \\
\hline
\end{tabular}

b) Output

Based on the input data and the formulas of the accompanying publications various $\mathrm{kgCO}_{2} \mathrm{e}$ emissions are calculated in different units ( $\mathrm{kgCO}_{2} \mathrm{e} / \mathrm{t}$, Total $\mathrm{kgCO}_{2} \mathrm{e}$, and Total $\mathrm{kgCO}_{2} \mathrm{e} / \mathrm{t}$ ) spread over various different windows. The results of the input in Section a) can be seen in Figure 6-3 for the plant and in Figure 6-4 for the project. A summary of these output values can be generated in .pdf format for each, the plant and the project. These reports have been enclosed for the above mentioned case in Figure 6-5. asPECT is dividing the results of its calculations into ten steps, from Step 1-3 Material extraction and processing to step 10 End of Life as depicted in Figure 6-4.

12 Assumption 


\begin{tabular}{|c|c|c|c|c|c|c|}
\hline $\begin{array}{l}\text { Mixture } \\
\text { Name }\end{array}$ & $\begin{array}{l}\text { Virgin } \\
\text { Mix kg } \\
\mathrm{CO} 2 \mathrm{e} / \mathrm{t}\end{array}$ & $\begin{array}{l}\text { RAP } \\
\text { Saving } \\
\mathrm{kg} \\
\mathrm{CO} 2 \mathrm{e} / \mathrm{t}\end{array}$ & $\begin{array}{l}\text { Transport kg } \\
\mathrm{CO} 2 \mathrm{e} / \mathrm{t}\end{array}$ & $\begin{array}{l}\text { Heating } \\
\mathrm{kg} \\
\mathrm{CO} 2 \mathrm{e} / \mathrm{t}\end{array}$ & $\begin{array}{l}\text { NonHeating } \\
\mathrm{kgCO} 2 \mathrm{e} / \mathrm{t}\end{array}$ & $\begin{array}{l}\text { Total } \\
\mathrm{kgCO} 2 \mathrm{e} / \mathrm{t}\end{array}$ \\
\hline AC11DS & 52,81 & 5.67 & 3.74 & 71.42 & 60,30 & 182.60 \\
\hline AC $32 \mathrm{TS}$ & 30.51 & 4.19 & 3.67 & 71.42 & 60,30 & 161.70 \\
\hline
\end{tabular}

\begin{tabular}{|c|c|c|c|c|}
\hline Type & CO2e Source & Amount & Unit & $\mathrm{kgCO} 2 \mathrm{e}$ \\
\hline Fuel & Natural Gas & 54465000 & $\mathrm{kWh}$ & 11.426 .757 .00 \\
\hline
\end{tabular}

\begin{tabular}{|c|c|c|c|c|}
\hline \multicolumn{5}{|c|}{ Nonheating Consumption Summary } \\
\hline Type & $\begin{array}{l}\mathrm{CO} 2 \mathrm{e} \\
\text { Source }\end{array}$ & Amount & Unit & $\mathrm{kgCO} 2 \mathrm{e}$ \\
\hline Electricity & Grid Electricity & 15496000 & $\mathrm{kWh}$ & $9.596 .672,80$ \\
\hline Fuel & Diesel & 16000 & litres & 51.961 .60 \\
\hline
\end{tabular}

Figure 6-3: Results of the plant [55] 


\begin{tabular}{|c|c|c|c|c|c|}
\hline \multicolumn{6}{|c|}{ Life Cycle Stage Summary } \\
\hline & \multirow{2}{*}{\multicolumn{2}{|c|}{ Material extraction and processing }} & $\mathrm{kg} \mathrm{CO} 2 \mathrm{e}$ & & Total kg CO2e \\
\hline Steps 1-3 & & & & 33.03 & 158.669 .22 \\
\hline Step 4 & \multicolumn{2}{|c|}{ Transport to plant } & & 3.69 & 17.731 .61 \\
\hline Step 5 & \multicolumn{2}{|c|}{ Asphalt production } & & 131.72 & 632.726 .72 \\
\hline Step 6 & \multicolumn{2}{|c|}{ Transport to site } & & 1.17 & $5.612,92$ \\
\hline Step 7 & \multicolumn{2}{|c|}{ Laying and compacting } & & 4,70 & 22.576 .59 \\
\hline Step 8 & \multicolumn{2}{|c|}{ Project works } & & 35,26 & $91.282,31$ \\
\hline Step 9 & \multicolumn{2}{|c|}{ Maintenance } & & 0.00 & 0.00 \\
\hline \multirow[t]{2}{*}{ Step 10} & \multicolumn{2}{|l|}{ End of life } & & 7.80 & 37.467 .53 \\
\hline & & Steps 1 to 7 & Asphalt & & Project \\
\hline \multicolumn{3}{|c|}{ Total kg CO2e } & 874.784 .59 & & 966.066 .91 \\
\hline \multicolumn{3}{|c|}{ tonnes } & 4.803 .53 & & $7.392,38$ \\
\hline \multicolumn{2}{|c|}{$\mathrm{kg} \mathrm{CO} 2 \mathrm{e}$ /tonne } & 174,31 & 182.11 & & \\
\hline
\end{tabular}

\begin{tabular}{|l|c|c|c|c|c|c|c|}
\hline Material & Tonnage & 1 to 3 & 4 & 5 & 6 & Total CO2e & Total CO2e/t \\
\hline AC11DS & $1.549,80$ & $73.050,62$ & $5.799,09$ & $204.141,51$ & $1.810,94$ & $284.802,15$ & 183.77 \\
\hline AC32TS & 3.253 .73 & $85.618,60$ & $11.932,53$ & $428.585,21$ & $3.801,98$ & $529.938,32$ & 162,87 \\
\hline
\end{tabular}

Figure 6-4: Result of the project [55] 


\section{asPECT Plant Summary Report}

Name: Scenario 0

Plant type: Batch

\section{Production}

Annual production ( $t$ ): 160.000

Materials available: 12

Mixtures available: 2
Date: 16.10 .2016

\section{Energy Usage (kWh)}

Annual Consumption: 70.131 .080

Process: 15.666.080

Heating and drying: 54.465 .000

\section{Environmental Impacts}

Total annual kg CO $2 \mathrm{e}: 21.075 .391$

$\mathrm{kgCO}_{2} \mathrm{e} /$ tonne: 132

Notes: None

Disclaimer: The data presented above is believed to be accurate and correct. It has however not been audited and no responsibility is held for errors resulting from misuse, misinterpretation or software failure.

\section{asPECT Project Summary Report}

Name: Scenario 1

Date: 16.10 .2016

Description: Database: Okobaudat

Asphalt

Number of courses: 2

Tonnage in courses: 4.804

\section{Siteworks}

Number of materials: 2

Tonnage of materials: 2.589

Total project tonnage: 7.392

\section{Environmental Impacts}

Total kg CO $2 \mathrm{e}: 966.067$

Asphalt kgCO $\mathrm{e} /$ tonne: 182

Notes: None

Disclaimer: The data presented above is believed to be accurate and correct. It has however not been audited and no responsibility is held for errors resulting from misuse, misinterpretation or software failure.

Figure 6-5: Report summary of the plant and the project [55] 


\section{C) Scenarios}

To determine the impact of different input values on the overall performance, different scenarios have been explored. To generalize the input all distances from and to the asphalt plant and to the construction site have been set to the same value for all scenarios except for Scenario 1. Additionally, due to the fact that according to the databases the emissions generated by the quarrying of all aggregates is the same they have been combined and their share of the asphalt mix pooled together. The data in section 6.2.1 has been set as the basic case (Scenario 0) and the explored scenarios have been modified based on it. All results of scenarios explored have been enclosed in Appendix B. $\underline{\text { Scenario } 1 \text { - Emissions according to different databases }}$

For the first scenario the emissions according to the British Defra's GHG Conversion Factors [48] have been used instead of the German values from ÖKOBAUDAT [47] for the aggregates. The aim of this scenario is to determine how differences in the emissions generated by the quarrying of the aggregates effect the overall emissions calculated for the project. This means instead of $33.8 \mathrm{kgCO}_{2} \mathrm{e} / \mathrm{t}$ emissions $11.0 \mathrm{kgCO}_{2} \mathrm{e} / \mathrm{t}$ are emitted for the quarrying of all aggregates. Some of the results of Scenario 1 in comparison to Scenario 0 can be seen in Table 6-6. Even though the emissions according to the British database are more than three times smaller than the German emissions the overall result for the project is only $12 \%$ smaller. This indicates that the effect of the initial emissions on the overall emissions is not linear and that other factors are involved. 
Table 6-6: Result Scenario 1

\begin{tabular}{|c|c|c|c|}
\hline Category & $\begin{array}{l}\text { Scenario } 0 \\
\text { [Total } \mathrm{kgCO}_{2} \mathrm{e} / \mathrm{t} \text { ] }\end{array}$ & $\begin{array}{l}\text { Scenario } 1 \\
{\left[\text { Total } \mathrm{kgCO}_{2} \mathrm{e} / \mathrm{t} \text { ] }\right.}\end{array}$ & Ratio \\
\hline AC11DS for Plant & 182.60 & 163.49 & $90 \%$ \\
\hline AC32TS for Plant & 161.70 & 152.51 & $94 \div$ \\
\hline AC11DS for Project & 183.77 & 164.66 & $90 \div$ \\
\hline AC32TS for Project & 162.87 & 153.68 & $94 \div$ \\
\hline Steps 1 to 7 & 174.31 & 161.92 & $93 \div$ \\
\hline Asphalt & 182.11 & 169.72 & $93 \div$ \\
\hline Project & $966,067.0$ Total $\mathrm{kgCO}_{2} \mathrm{e}$ & $847,614.0$ Total $\mathrm{kgCO}_{2} \mathrm{e}$ & $88 \div$ \\
\hline
\end{tabular}

\section{Scenario 2 - Plant consumption and production}

In a second scenario the impact of the amount of production and consumption of the plant have been explored by changing the input values gradually $(-50 \%,-25 \%,+25 \%,+50 \%,+75 \%,+100 \%)$. This scenario has been explored even though the roadway engineer cannot influence the performance of the asphalt plant. However, it might be interesting to see how the performance of the plant effects the projects emissions. The result generated by asPECT indicate that apart from an increase of the emissions generated by the plant the production and consumption of the plant has no impact on the overall emission of the project. The Total

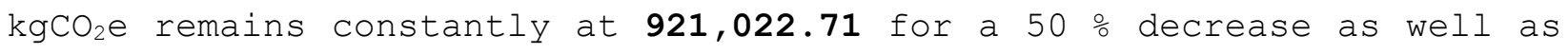
for a 100 \% increase of the plant production and consumption. This result indicates that there is no effect of the plant on the overall performance which is rather unexpected and might be due to the formulas used by asPECT to determine the emissions. However, the share of the asphalt production on the overall emissions is with $66 \%$ the biggest of all life cycle steps. Table 6-7 and Graph 6-1 illustrate the distribution of the impacts of each life-cycle step on the overall emissions generated by the project. 
Table 6-7: Distribution of impact of life-cycle steps on overall emissions

\begin{tabular}{|l|l|l|}
\hline LC Step & Description & Share \\
\hline Step $\mathbf{1 - 3}$ & Material extraction and processing & 16\% \\
\hline Step $\mathbf{4}$ & Transport to plant & 2\% \\
\hline Step 5 & Asphalt production & $66 \%$ \\
\hline Step $\mathbf{6}$ & Transport to site & 1\% \\
\hline Step $\mathbf{7}$ & Laying and compacting & 2\% \\
\hline Step $\mathbf{8}$ & Project works & 9\% \\
\hline Step $\mathbf{9}$ & Maintenance & $0 \%$ \\
\hline Step $\mathbf{1 0}$ & End of life & 4\% \\
\hline
\end{tabular}

\section{Distribution of impact of life-cycle steps}

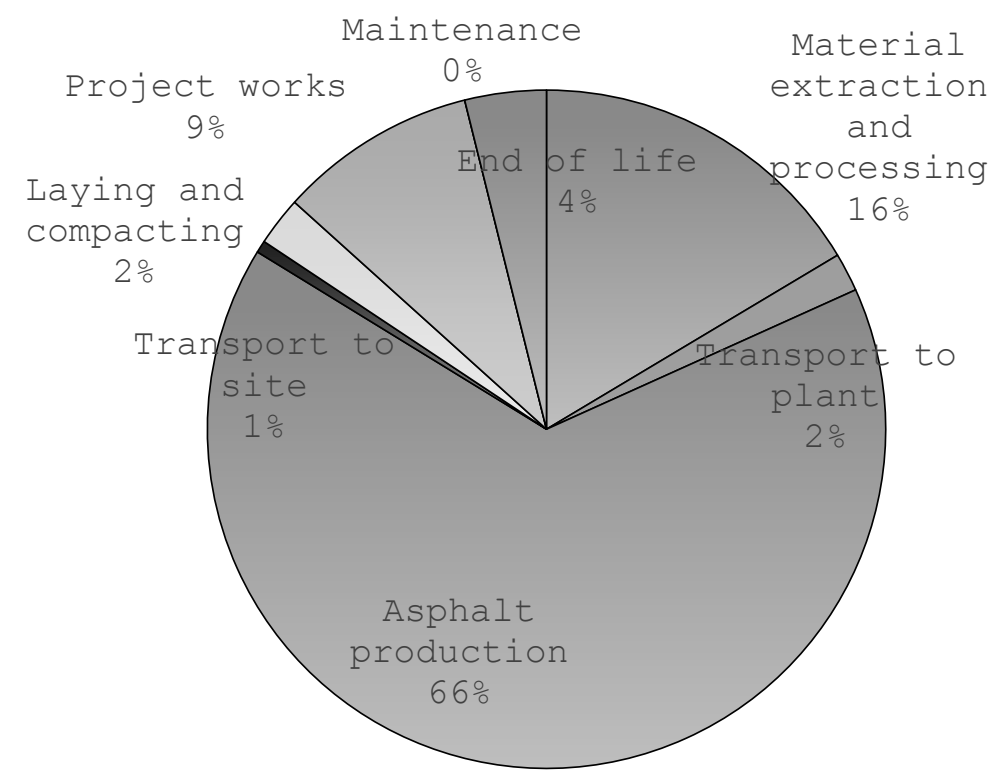

Graph 6-1: Illustration of impact distribution of life-cycle steps, asPECT 
Scenario 3 - Amount of crushed asphalt in mix

Another aspect that has been explored is the impact of the amount of crushed asphalt in the mix design of the base layer AC32TS. As already mentioned in section 2.4 the amount of crushed asphalt has increased gradually since 1988 and a positive impact of the amount of crushed asphalt on the overall emissions might be an incentive to promote the research into the recycling of asphalt further. The values that have been explored ranged from $25 \%$ crushed asphalt and $75 \div$ virgin material to 75 \% crushed asphalt in steps of $5 \%$. Graph 6-2 illustrates that the amount of crushed asphalt on the overall emissions of the project is linear and with a decreasing share of reclaimed material the Total $\mathrm{kgCO}_{2} \mathrm{e}$ is increasing. Graph 6-2 also illustrates that the amount of crushed asphalt has an effect on both the emissions of the asphalt component of the project as well as the life-cycle steps from cradle to installation. The slope of all three lines is the same, indicating that the effect on all three aspects considered here is the same.

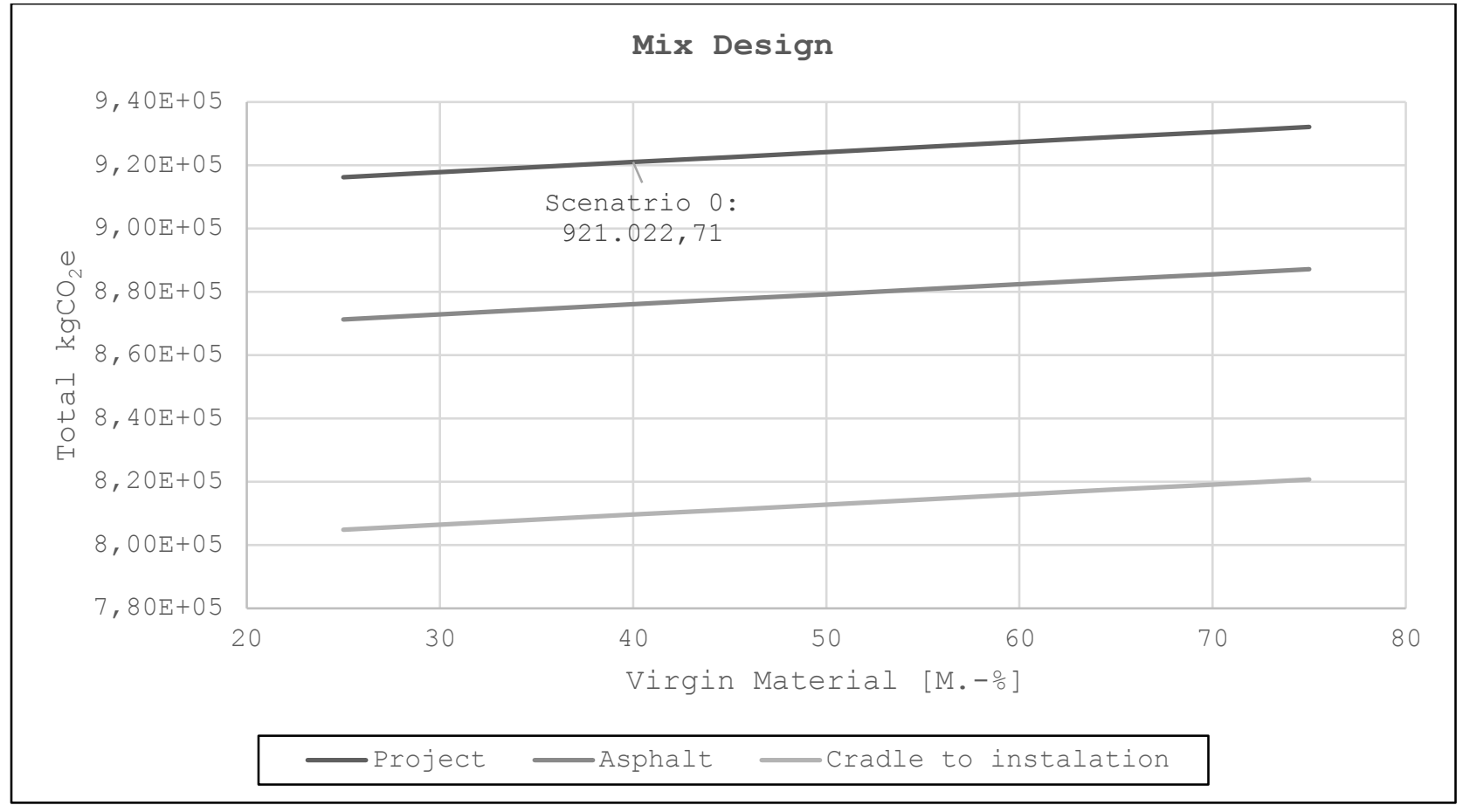

Graph 6-2: Impact of asphalt composition on Total $\mathrm{kgCO}_{2}$, asPECT 
Scenario 4 - Distances

The forth variable that has been explored are the distances to the asphalt plant, from asphalt plant to construction site and from construction site to waste treatment site. The decision which supplier has to be hired is influenced by various factors, only one of them being the distances travelled. Other considerations are, among others economic factors or availability of products. It might not be feasible to hire suppliers further away for ready made products such as asphalt. However, for aggregates or base layers sourced from cheaper suppliers further away might be more economic no matter the environmental impact of the longer transportation route. Distances from 10 to $100 \mathbf{k m}$ with $10 \mathrm{~km}$ steps have been examined. With increasing distances the overall emissions of the project are increasing linearly as can be seen in Graph 6-3. It can also be seen, that the impact on the aspects concerned with asphalt is bigger than the impact on the cradle-to-installation steps of the life-cycle. The slope of the 'Asphalt' line (8 771) is bigger than the slope of the 'Cradle to installation' line (5 872). However, the sustainable concept is not only comprised of the environmental factor but also of economic considerations. Thus if both factors, environment and economy are considered simultaneously it might be more sustainable to source the material from a plant farther away from the asphalt plant or construction site, if the economic factor is big enough to outweigh the environmental aspect. 


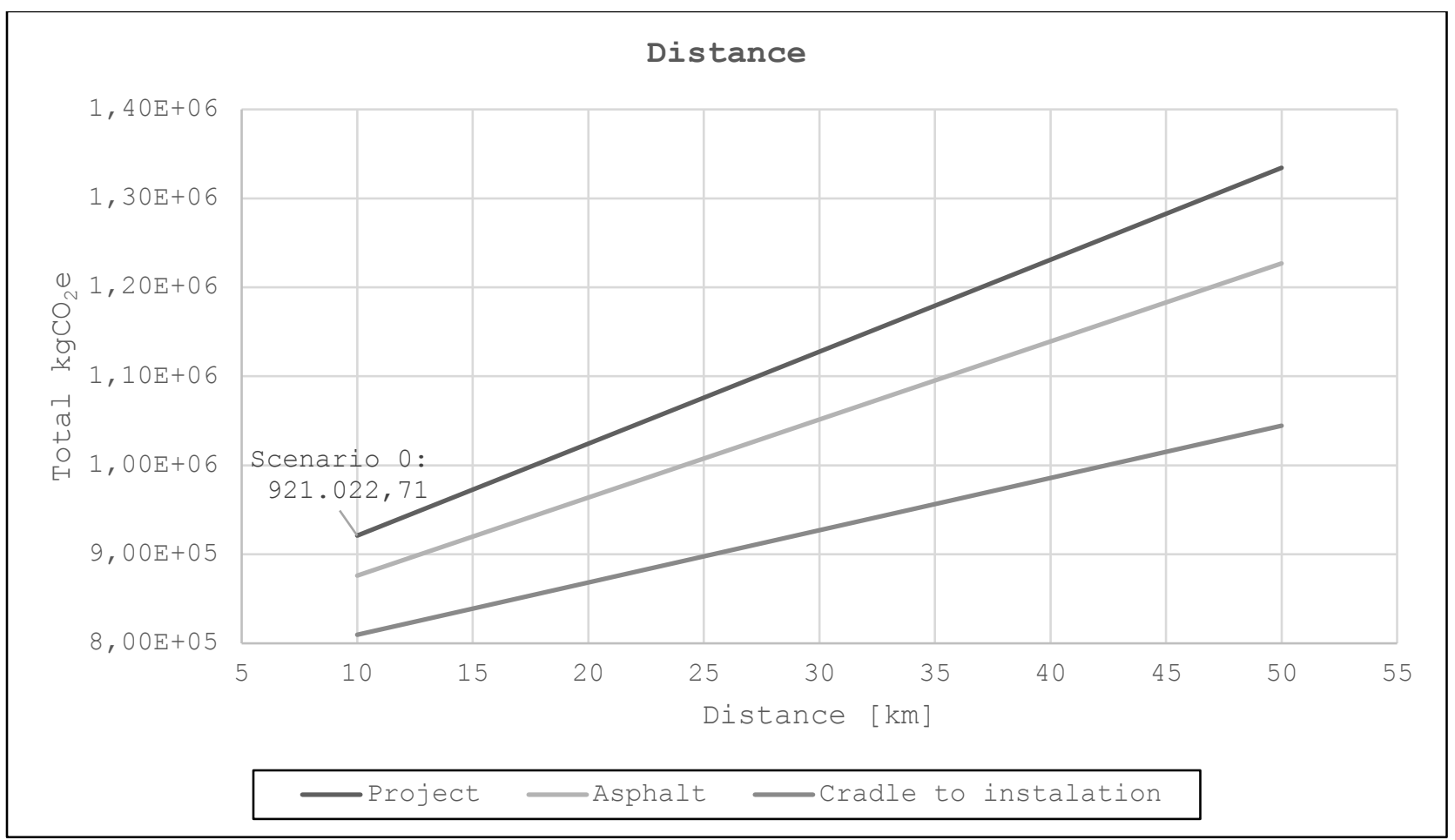

Graph 6-3: Impact of traveled distances on Total $\mathrm{kgCO}_{2} \mathrm{e}$, asPECT 


\section{Scenario 5 - Excavation treatment}

asPECT has two options of excavation treatment, disposing on a landfill plant and storage on a stockpile site. Options from 100 \% landfilled to $100 \%$ stockpiled with steps of $10 \%$ in between have been explored for Scenario 5. Graph 6-4 is illustrating that the impact is again increasing linear with an increasing share of landfilled material. It can also be seen in Graph 6-4 that the impact of the type of excavation treatment has no effect on the life-cycle steps from cradle to installation as can be expected as the excavation treatment is an end of life measure.

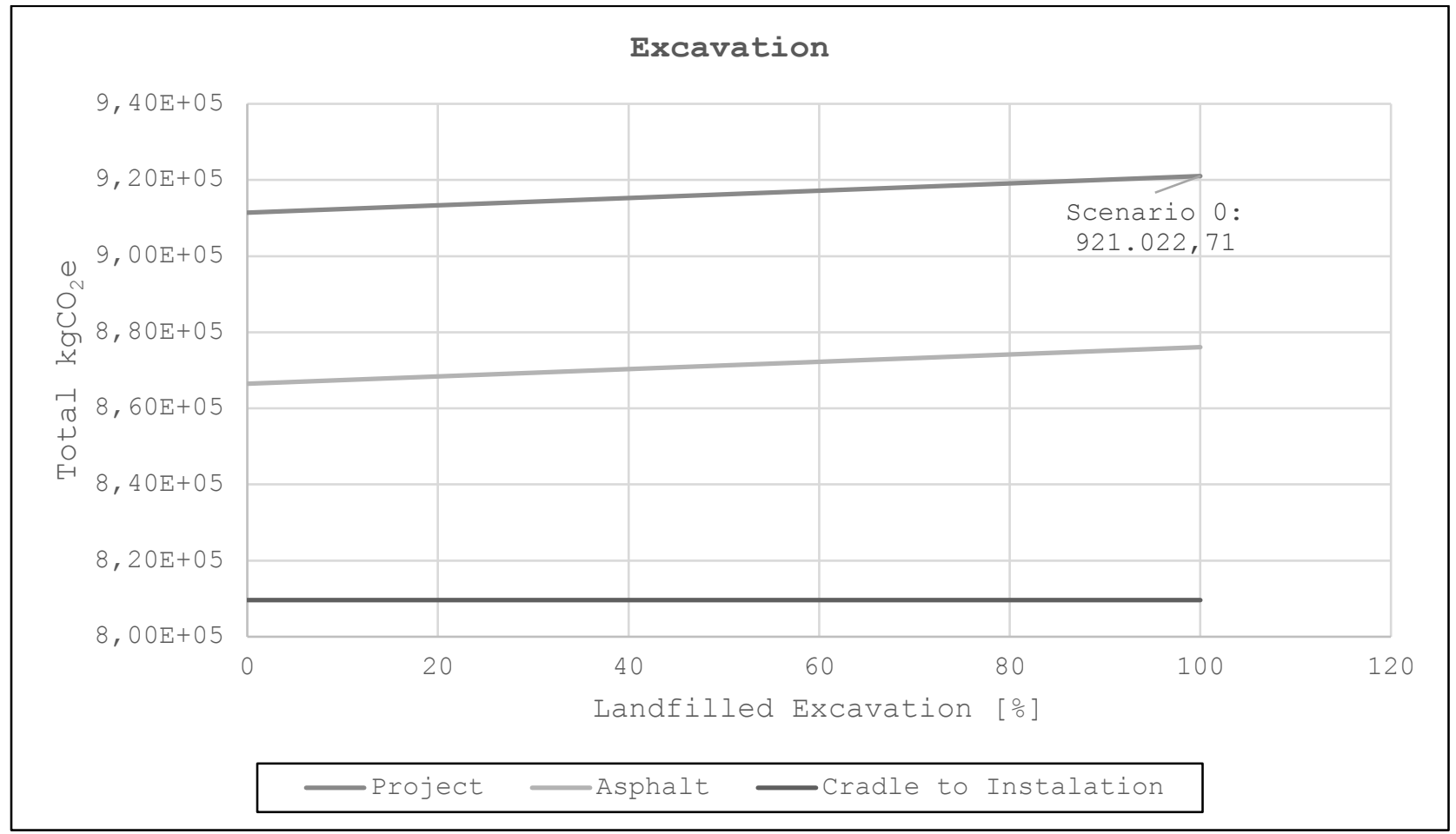

Graph 6-4: Impact of excavation treatment on Total $\mathrm{kgCO}_{2} \mathrm{e}$, asPECT 
Scenario 6 - Heating time of asphalt mix

In addition to the five scenarios previously described the impact of the heating time of the asphalt mix in the asphalt plant on the emissions has been investigated. It has become evident, that there is no effect on any of the emissions calculated by asPECT. Varying the heating time between the two asphalt types available at the plant also has no effect on the overall result.

\section{2 .2 Summary}

asPECT is a detailed concept and considers numerous aspects of the construction process. The necessary preparatory work for the application of asPECT is rather comprehensive. The data needed is detailed and the scenarios examined in this section indicate that the effect of the input data on the output is rather small. However, once all necessary data has been gathered the application of the software tool is intuitive even though the manual does not really give explanations about which value is needed for all input fields, the tool is fast to apply. The accompanying guidance and protocol are comprehensive and illustrate the considerations the application is based on.

Due to the fact that the concept is related to the governmental GHG conversion factors and Defra's reporting guideline for the mandatory reporting of GHG emissions British companies might already have the necessary data for the application of the software which would simplify the preparatory work necessary.

The design of the software tool does not allow a fast comparison of different variations of one project. The whole project has to be copied into a new file before changing any input, otherwise the previous input will be overwritten. Furthermore, does the final result not include any detailed information about emissions generated by the project even though they are calculated by the software, these values have to be copied 
manually into for instance an excel sheet to generate tables and graphs of what has been calculated by the software. The amount of input and the detail of output is not proportionate to the simplicity of the final report generated by the tool. 


\subsection{Athena Pavement LCA}

The Canadian Athena Sustainable Materials Institute developed in association with the Cement Association of Canada the Athena Pavement LCA tool to enable pavement designer to include environmental considerations into their decision making process. The tool is, similarly to the British tool asPECT, based on the Life Cycle Assessment concept of the International Standards ISO 14040 and ISO 14044 providing a 'cradle-to-grave' profile for a given road section. The following aspects are included in the results generated by the Athena Pavement LCA:

- Flows from and to nature

- Energy and raw materials flows

- Emissions to air, water and land

The software tool is also available as online application and based on several databases about materials, energy and transportation specific to various regions of Canada and parts of the US. [59]

The US EPA TRACI, the 'Tool for the Reduction and Assessment of Chemical and Other Environmental Impacts' from the United States Environmental Protection Agency has been used as a template for the assessment tool. TRACI has been developed to provide a framework for sustainability evaluations. Athena Pavement LCA has adopted from TRACI the pollution categories: ozone depletion, global warming, human health, smog formation, acidification, and eutrophication. [49, 60]

\subsubsection{Application of Athena Pavement LCA}

\section{a) Input}

The first information needed for the application of the Athena tool is the lifespan of the project as well as the location and average distances between the construction site and the plant, stockpile and equipment depo respectively. For the projects life span a range from 30 to 50 years are 
available, here 30 years have been chosen. From the tool different locations in Canada are available to select from, the location chosen here is Eastern Ontario as it has a climate relatively similar to the German climate with no extreme temperatures. For the distances ten kilometers have been input. The input is summarized in Table 6-8.

Table 6-8: General project information

\begin{tabular}{|l|l|}
\hline Information & Amount \\
\hline Projects lifespan & 30 years \\
\hline Project location & Ontario East \\
\hline Average Distance Plant to Site & $10 \mathrm{~km}$ \\
\hline Average Distance Site to Stockpile & $10 \mathrm{~km}$ \\
\hline Average Distance Equipment Depot to Site & $10 \mathrm{~km}$ \\
\hline
\end{tabular}

In a second step a new roadway section is created specifying the initial cost, the length as well as the number of lanes and the number of pavement layers. Additional information about the type of materials used are entered here. There are numerous materials including their emissions available to choose from and it is also possible to generate individual materials. The cost of the project according to the data from the Landratsamt Karlsruhe has been converted from $€$ into CAN $\$$ using a conversion factor of 1.45 . The length of the roadway section is $2.35 \mathrm{~km}$. The number of lanes is two with two asphalt layers and one granular layer, thus the type of pavement is flexible. The shoulders of the given road are unpaved on both sites. Table 6-9 is giving a summary of the input data for the roadway. 
Table 6-9. Roadway information

\begin{tabular}{|l|l|}
\hline Information & Amount \\
\hline Initial cost & CAN \$ 586,756.14 \\
\hline Lane length & $2.35 \mathrm{~km}$ \\
\hline \# of lanes & 2 \\
\hline \# of pavement lifts & 2 \\
\hline \# of granular layers & 1 \\
\hline Type pf pavement & Flexible \\
\hline Type of shoulder & Unpaved \\
\hline
\end{tabular}

\section{Roadway Cross Section}

\begin{tabular}{|c|c|c|c|}
\hline Left Side & \multicolumn{2}{|c|}{ Lanes } & Right Side \\
\hline \multirow{3}{*}{$\begin{array}{l}\text { Shoulder } \\
\text { Unpaved }\end{array}$} & Lane 1 Lift 1 & Lane 2 Lift 1 & \\
\cline { 2 - 3 } & Lane 1 Lift 2 & Lane 2 Lift 2 & Unpaved \\
\hline \multicolumn{3}{|c|}{ Granular Layer 1 } \\
\hline
\end{tabular}

Figure 6-6: Cross section generated by Athena [48]

Based on that the software is generating a diagram of a cross section. The cross section generated for the given input can be seen in Figure 6-6. The types of materials used for each layer as well as its thickness and width are input here. Default materials have been chosen at this point as the information needed by

Athena to generate the materials used for the rehabilitation of the K3533 have not been available. The materials chosen are depicted in Table 6-10. Based on the input the software is then calculating the density in $t o / \mathrm{m}^{3}$, the mass in to, the area in $\mathrm{m}^{2}$ and the volume in $\mathrm{m}^{3}$ of each layer.

Table 6-10: Details about roadway design

\begin{tabular}{|l|l|l|l|}
\hline Layer & Material & Width [m] & Thickness [mm] \\
\hline Granular Layer 1 & Granular A & 6 & 10 \\
\hline Lane 1 and 2 Lift 1 & HMA PG 64-22 & 3 & 4 \\
\hline Lane 1 and 2 Lift 2 & GDM 37.5 & 3 & 14 \\
\hline Shoulder & ON Granular B & 1.5 & 28 \\
\hline
\end{tabular}


The third step when applying Athena Pavement LCA is to determine the equipment used for the construction as well as for the material transport. Default values about the fuel consumption and production rate of various equipment are already included. The equipment used here is listed in Table 6-11.

Table 6-11: List of construction equipment

\begin{tabular}{|l|l|}
\hline Activity & Equipment \\
\hline Asphalt Paving HMA & Asphalt Paver \\
\cline { 2 - 2 } & Compactor \\
\cline { 2 - 2 } & Roller \\
\hline \multirow{2}{*}{ Earth Excavation } & Excavator $>50,<100 \mathrm{Hp} 13$ \\
\cline { 2 - 2 } & Excavator $>100,<250 \mathrm{Hp}$ \\
\hline Granular Compaction & Compactor \\
\hline On Road Hauling & Dump Truck \\
\hline
\end{tabular}

b) Output

After finishing the input process reports about the following aspects can be generated and exported to MS Excel:

- Bill of materials

- Summary measures

- Energy consumption

- Air emissions

- Land emissions

- Water emissions

- Resource use

For each aspect the results are structured in six life-cycle-stages: manufacturing (1), construction (2), maintenance (3) and rehabilitation embodied totals (4), and two use phases, roadway operating energy (5) and excess fuel consumption due to pavement vehicle interaction

$13 \mathrm{Hp}=$ Horse power 
(PVI) (6). In addition to tables, graphs of the results are generated illustrating the output.

The results are divided into various indicators of the environmental impact:

(1) Global Warming Potential $\rightarrow \mathrm{kg} \mathrm{CO} 2$ eq

(2) Acidification Potential $\rightarrow \mathrm{kg} \mathrm{SO} \mathrm{SO}_{2}$ eq

(3) Eutrophication Potential $\rightarrow \mathrm{kg} \mathrm{N}$ eq

HH Particulate

$\rightarrow \mathrm{kg} \mathrm{PM} \mathrm{PM}_{2.5} \mathrm{eq}$

Ozone Depletion Potential

$\rightarrow \mathrm{kg} \mathrm{CFC}-11$ eq Smog Potential

$\rightarrow \mathrm{kg} \mathrm{O}_{3}$ eq

Total Primary Energy

$\rightarrow \mathrm{TPE} \mathrm{MJ}$

Fossil Fuel Consumption

$\rightarrow \mathrm{FFC} \mathrm{MJ}$

Non-Renewable Energy

$\rightarrow \mathrm{NRE} \mathrm{MJ}$

As already mentioned in Section 6.2 the Global Warming Potential (1) is a measure developed to allow a comparison of the impacts of different gases. Acidification (2) is the reduction of the $\mathrm{pH}$ level, eutrophication (3) the reduction of the oxygen dissolved in water. [56]

The HH Particulate (4) is referring to the human health particulate, the potential for air emissions. The Ozone Depletion Potential (5) is the ozone depletion potential for air emissions whereas the Smog Potential (6) is referring to the potential of smog formation for air emissions. [61]

The primary energy consumption (7) is comprised of the consumption of the energy sector itself with losses during transformation and distribution of energy as well as the final consumption of a product. The consumption of non-renewable natural energy sources is here labeled as fossil fuel consumption (8) . [62] 
Non-renewable energy (9) is energy from sources that cannot be regenerated in a short period of time. In addition to all fossil fuels non-renewable energy includes uranium ore which is used in nuclear power plants. [63]

C) Scenarios

For the application of Athena only the fourth scenario explored with the British assessment tool asPECT can be applied due to the type of data input in the tool. However different aspects can be explored with the Canadian assessment tool. Athena allows as opposed to asPECT to copy already existing projects which makes it easier to explore scenarios where only one or two variables change. It is also possible to compare different solutions when generating the results. The results of the scenarios explored have been enclosed in Appendix C.

Scenario 0

In analogy with section 6.2 Scenario 0 is the case described above with input according to the rehabilitation of the K3533. The results depicted in Graph 6-5 indicate that the values are the highest for the construction material and the embodied effects material and equipment and the lowest for manufacturing transportation. However, the difference between the two highest values and the third highest value, manufacturing material varies between the categories.

The impact of the different life-cycle steps in relation to the overall results has also been illustrated in Table 6-12 and Graph 6-6. These results show that the share of transportation aspects is close to zero, the impact of the material manufacturing is also relatively small compared to the construction equipment and the embodied effects of material and equipment. 


\section{Summary Measures by Life Cycle Stage Clustered Column Chart}

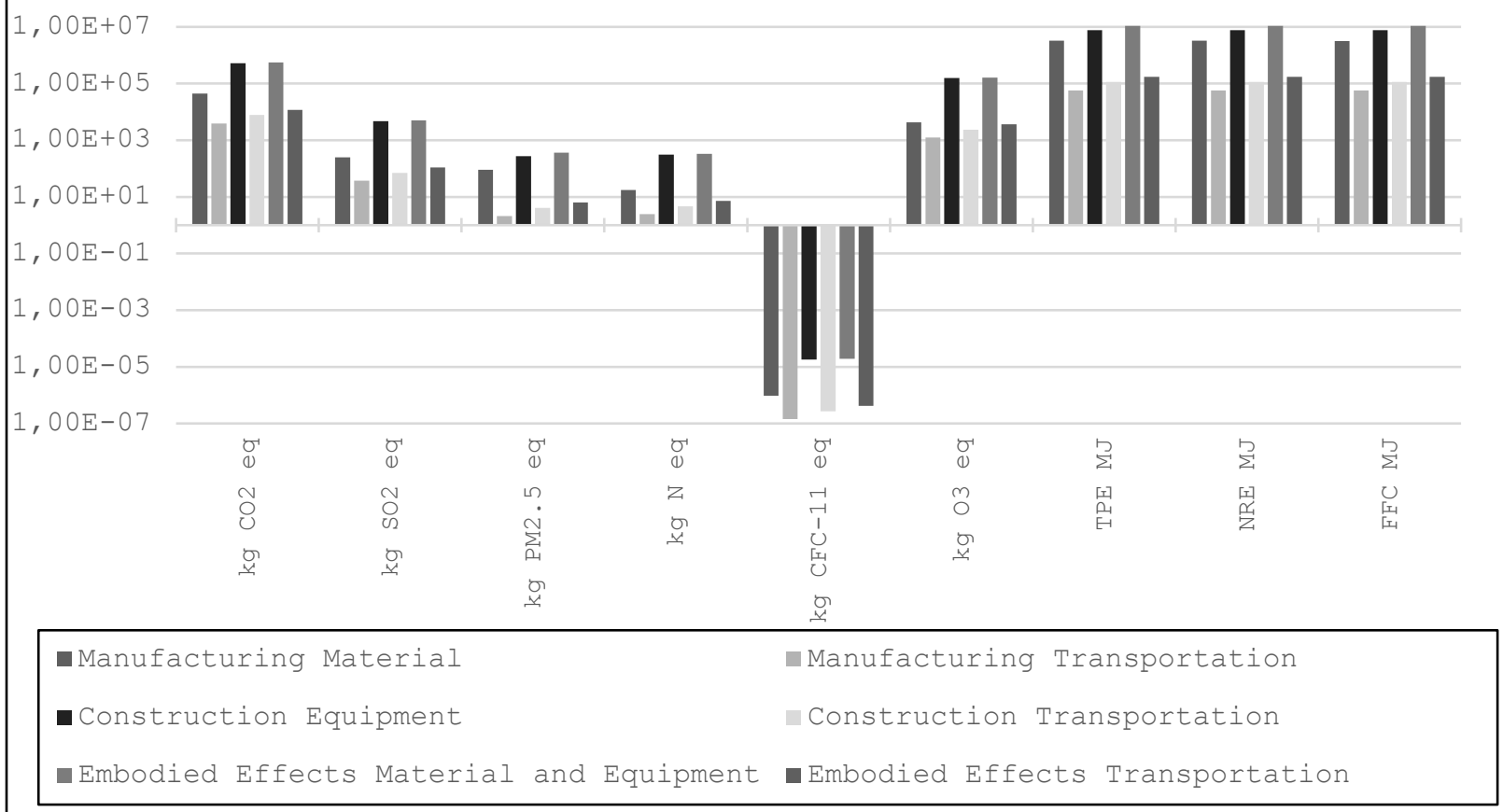

Graph 6-5: Summary of results for Scenario 0, Athena

Table 6-12: Distribution of impact of life-cycle stages

\begin{tabular}{|l|l|}
\hline Life-cycle Stage & Share \\
\hline Manufacturing material & $3.8 \%$ \\
\hline Manufacturing transportation & $0.3 \%$ \\
\hline Construction equipment & $45.2 \%$ \\
\hline Construction transportation & $0.7 \%$ \\
\hline Embodied effects material and equipment & $49.0 \%$ \\
\hline Embodied effects transportation & $1.0 \%$ \\
\hline
\end{tabular}




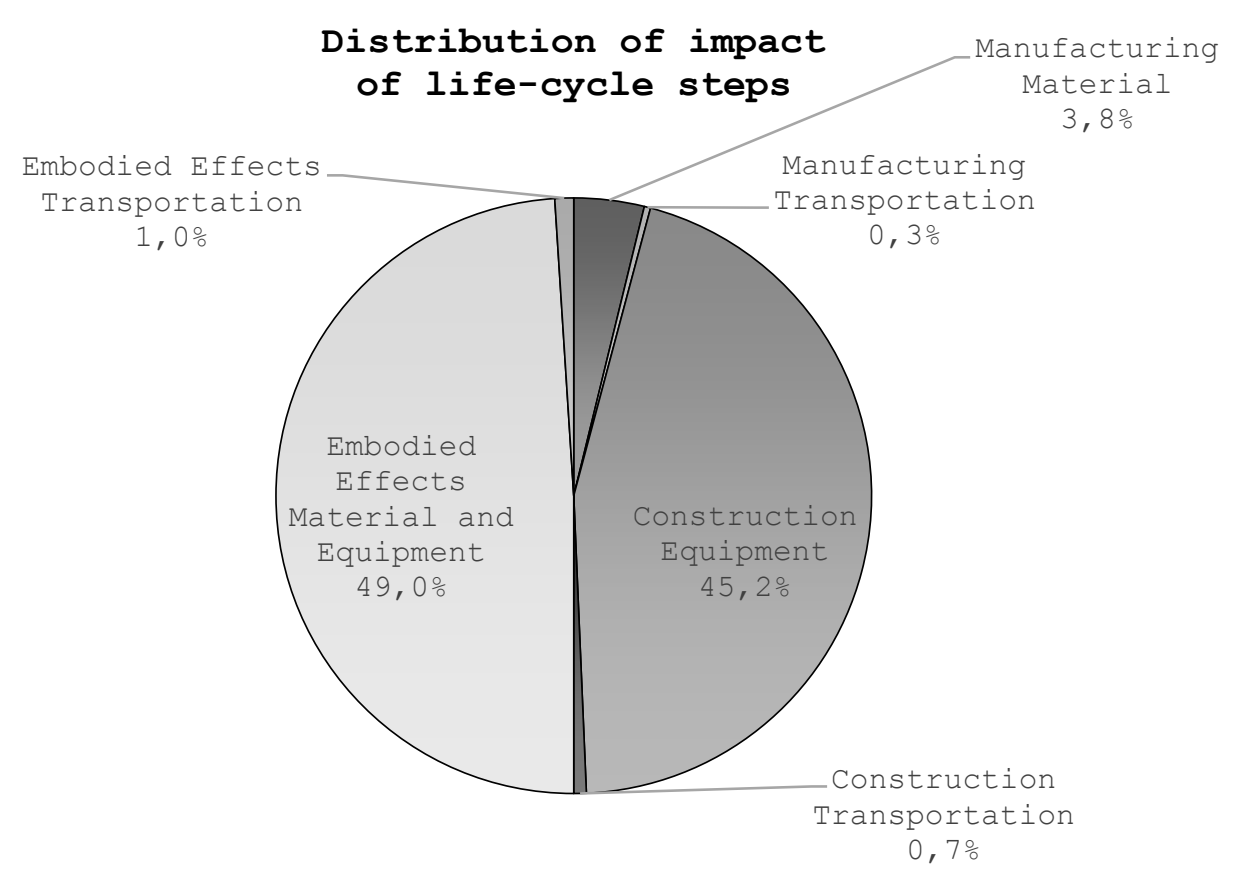

Graph 6-6: Illustration of impact distribution of life-cycle steps, Athena

Scenario 1 - Distances

Similar to Scenario 4 of the application of the British software in Section 6.2 the distances plant - site - stockpile - equipment depot have a linear effect on the overall emissions when using Athena. Graph 6-7 shows the impact of different distances from $30 \mathbf{k m}$ to $90 \mathbf{k m}$ in steps of $20 \mathrm{~km}$ related to Scenario 0, in Scenario 0 the distance has been $10 \mathrm{~km}$. However, when considering the bars depicting the total emissions of the construction and embodied effects aspect there is almost no effect of the transportation emissions. Which is analog to the results in Table 6-12 and Graph 6-6, showing that the share of the transportation aspect of the overall emissions is much smaller than the others. 


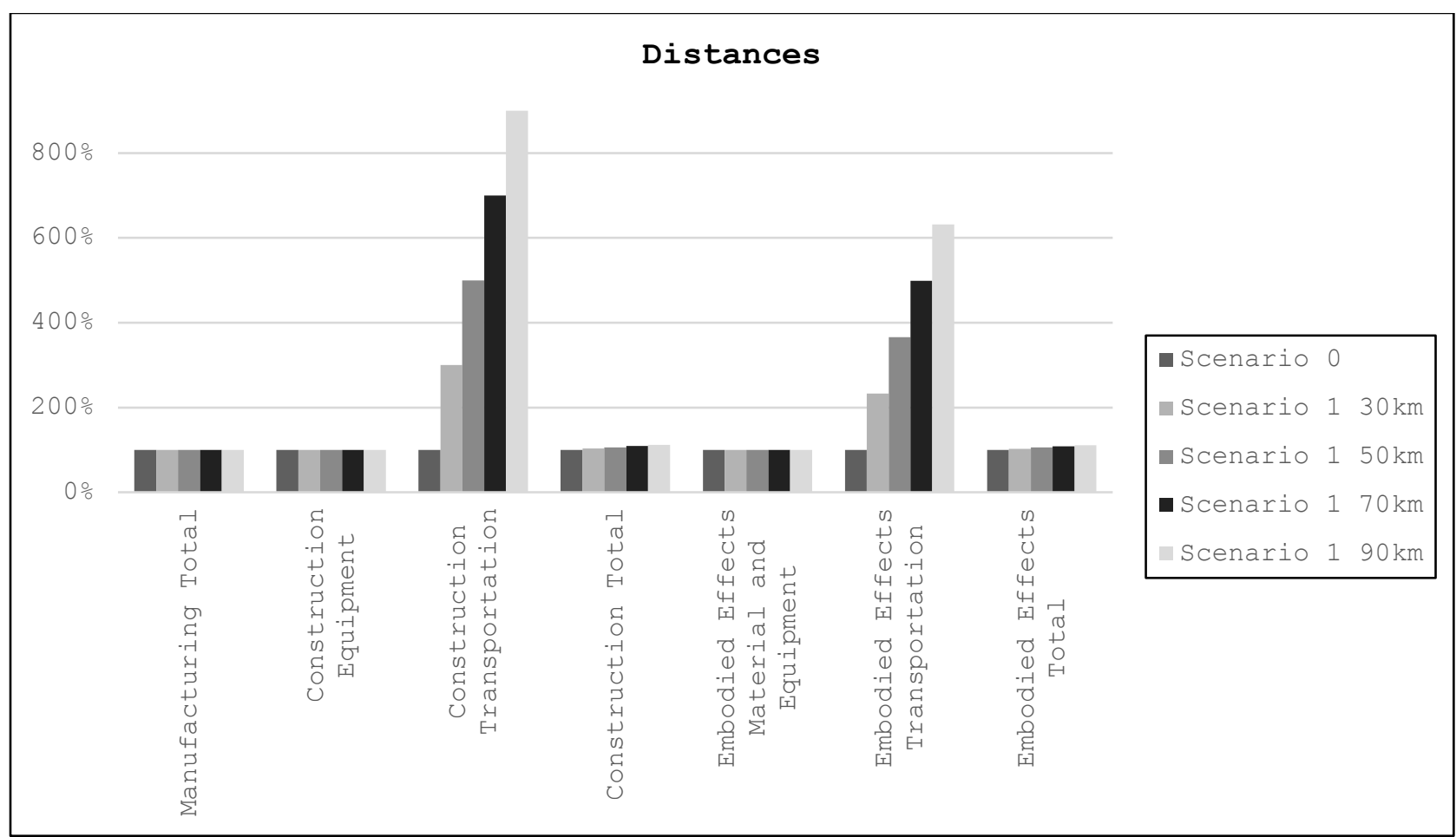

Graph 6-7: Impact of different distances on Global Warming Potential in relation to Scenario 0, Athena 
Scenario 2 - Length of roadway section

Scenario 2 explores the impact of different road lengths, from $2.35 \mathrm{~km}$ for Scenario 0, and $3 \mathrm{~km}$ to $7 \mathrm{~km}$ in steps of $1 \mathrm{~km}$. The length of the road section under construction has a linear effect on the emissions in relation to Scenario 0. Graph 6-8 also illustrates, that the emissions of the transportation element of the manufacturing is increasing much faster than the construction and embodied effects element. Which might be due to a smaller effect of the roadway length on the construction and embodied effects aspect of the project. Compared to Scenario 1 the values are increasing more gradually for scenario 2 than for scenario 1, however, the steps between the distances are bigger than between the road section lengths. This scenario has been explored to determine if it would be reasonable in terms of emissions to rehabilitate a small number of bigger road sections instead of a greater number of small road sections. The results obtained indicate that an increase in length within the range explored here has no decreasing effect on the overall emissions.

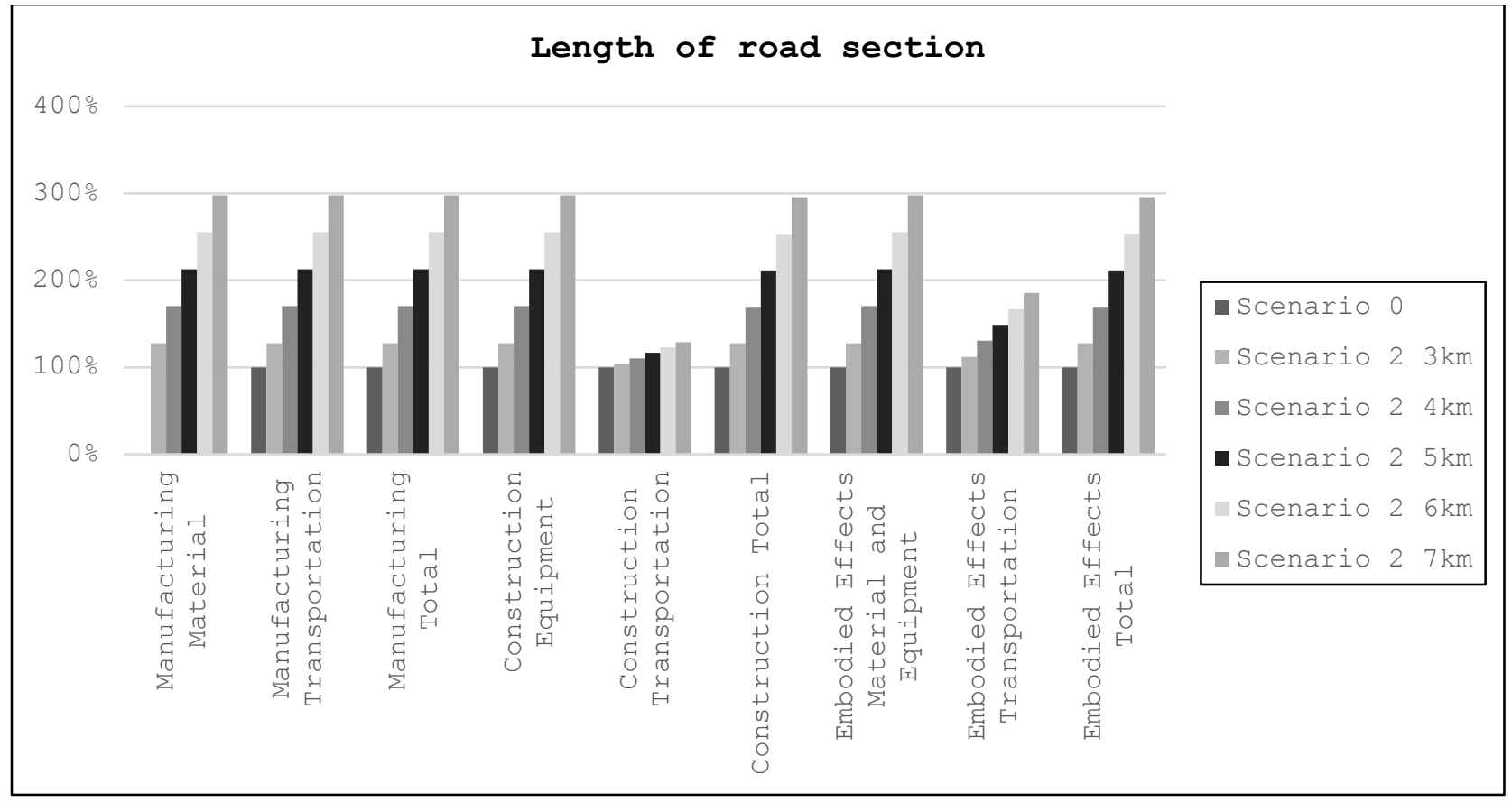

Graph 6-8: Impact of different road section lengths on Global Warming Potential in relation to Scenario 0, Athena 


\section{3 .2 Summary}

The concept of Athena for their Pavement LCA tool is to provide an extensive library of emissions values for materials, pavement structures, equipment and construction process based on a large number of construction projects. This allows a fast application without the need for comprehensive information about the given construction project which might not be readily available. At the same time the tool allows for specific data to be input if desired. With Athena it is possible to input and compare different scenarios and to generate reports including illustrations. The design of the software can be understood intuitively and the different input states are clearly structured.

However, the use of the default values leads to a lack of transparency and the user cannot easily comprehend what has been calculated to generate the results and which aspects of the production process have been included. This might lead to misinterpretations of the results.

For the sustainability evaluation of a road rehabilitation the software could be adapted for the calculation of some of the environmental factors. Due to the fact that Athena Pavement LCA is available as online application as well as downloadable software the user can chose which option is preferable. For this thesis the online application has been used, however the software has more advanced features which generate a more detailed evaluation. 


\subsection{SEVE Eco-Comparateur}

The French 'Eco-Comparateur' SEVE [64] (Système d'Evaluation des Variantes Environnementales) has been developed in response to the Voluntary Commitment Agreement from 2009 of the Grenelle Environment Round Table, especially to article 5 of the agreement:

5 Improving the environmental performance of companies and
infrastructures: By promoting (from september, 2009) the
comparison of environmental solutions through the creation
of an "Eco-comparer" shared by the companies and validated
by the Environmental and Energy Control Agency (ADEME),
based on energy consumption, greenhouse gas emissions and
the preservation of natural resources. [65, p. 5]

The agreement has been signed by four professional associations and two public bodies who are also responsible for the development of SEVE.

Large construction companies have introduced internal assessment tools to evaluate ecological performances, e.g. Gaïa.BE ${ }^{\circledR}$ for Eurovia and Ecologiciel for the Colas Group. These companies enclosed with their bids in response to tender an ecological evaluation. SEVE is supposed to be used to compare different responses to tender and their enclosed ecological evaluations. The main focus is on the evaluation of differences between the responses to tender due to either direct requirements in the contract, e.g. the choice of materials or individual waste management solutions or due to proposals for technical variations to the one advertised for bids. Responses to tender are according to the SEVE manual often evaluated as follows:

- Cost of services (60\%)

- Technical value (20\%)

- Ecological value (20\%) 
SEVE can be used either for the bid evaluation or by the company responding to an invitation to tender to evaluate their solution or solutions. [65]

SEVE is a free online tool and can be accessed in English from the website interntional.seve-tp.com. The data is updated every 3 years. The aspects of the life-cycle considered by SEVE are depicted in Figure 6-7. SEVE is considering a partial life cycle from 'cradle-toinstallation'. Due to the fact that it is difficult for companies to specify data about maintenance and

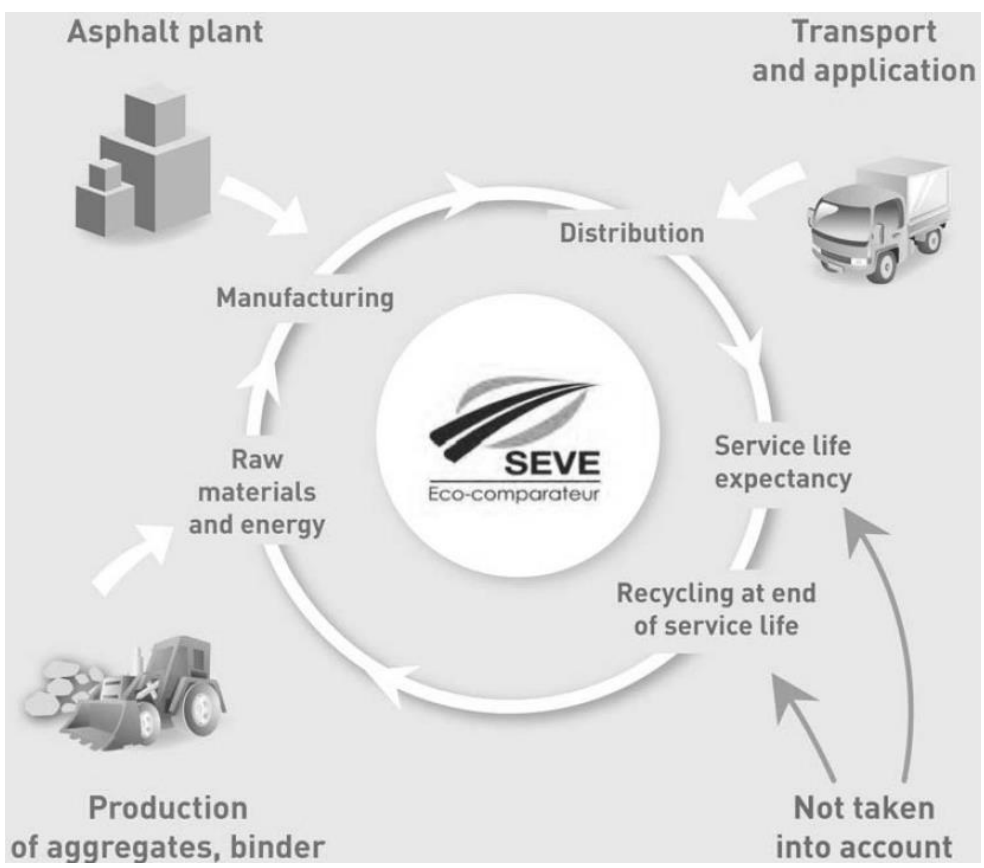

Figure 6-7: Partial LCA considered with SEVE [65]

end of life treatment when responding to an invitation to tender these steps of the LCA are not considered. [65]

SEVE has different access types, the system administrator for example manages the shared database as well as the individual data of the member companies. For this thesis access as an 'engineer of business unit' has been granted allowing to use the data already available in SEVE to create a project and generate a final report. [65] 
The final report generated by SEVE is comprised of five elements depicted in Figure 6-8.
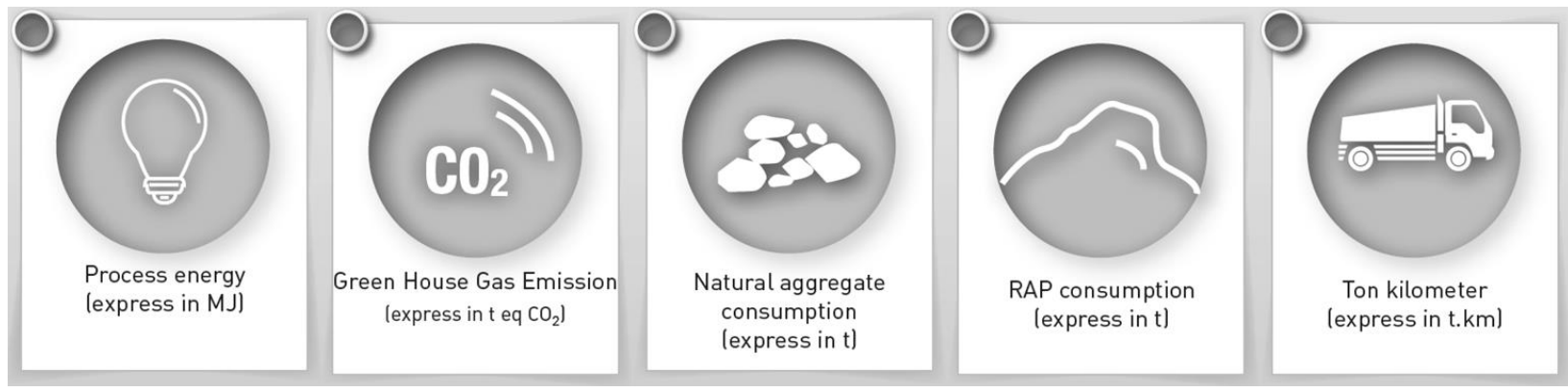

Figure 6-8: Five indicators considered with SEVE [66]

The energy consumption is the sum of all energies needed for the construction works, renewable and none renewable, without the fuel used as a raw material. The GHG emissions are calculated by multiplying the quantity of gases emitted by their global warming potential to obtain the results in the unit $\mathrm{CO}_{2} \mathrm{e}^{14}$. The third element, the natural resources saving represents the difference in natural resources used by the options of the responses to tender compared by SEVE. The RAP content is the quantity of reclaimed asphalt pavement used for each option. The final comparison is given in a table with the specific values as well as in a chart visualising the performance of each option in relation to the others. The fifth aspect is the amount of materials transported multiplied by the number of kilometers driven. [65]

14 GWP of $\mathrm{CO}_{2}=1 \mathrm{~kg} \mathrm{CO}$ e per $\mathrm{kg}$

GWP of $\mathrm{CH}_{4}=21 \mathrm{~kg} \mathrm{CO}$ e per $\mathrm{kg}$

GWP of $\mathrm{N}_{2} \mathrm{O}=310 \mathrm{~kg} \quad \mathrm{CO}_{2} \mathrm{e}$ per $\mathrm{kg}$ 


\subsubsection{Application of SEVE}

The following section will describe the application of SEVE using an 'engineer of business unit' account. After generating a new project the next step is to create a solution and different operations within the solution. The incoming products, pieces of equipment needed and outgoing products can be specified stating the following information:

- Distance from production to construction site for incoming products and vice versa for outgoing products

- Quantity delivered or removed

- Mode of transportation

- Number of days the equipment has been used

Using an 'engineer of business unit' access it is not possible to add new materials specific to the rehabilitation of K3533 to the database of SEVE, however it is possible to modify some already existing materials and products in accordance with the first four indicators described in Section 6.4, energy consumption, GHG emissions, natural recourses, and RAP content. Materials that can be modified are for example aggregates or concrete. Asphalt is only available as product of specific production companies, with default values for the indicators above, the only option is to change the distance driven and the amount delivered.

d) Input

The following table (Table 6-13) illustrates which materials have been chosen as substitute for the materials used for the rehabilitation of the K3533. The associated environmental costs for the two asphalt layers are default values for a given asphalt plant. Similarly, the values for the removed material and the emulsion are also default. However, the energy and $\mathrm{CO}_{2}$ consumption for the base layer has been input according to the data from ÖKOBAUDAT and the values for the virgin aggregates and RAP content have been assumed. The differences in the magnitude between the default values and the values from ÖKOBAUDAT indicate that the 
databases may be based on different considerations with regard to what is included into the calculations of the environmental impact.

Table 6-13: Chosen materials for road layers and associated consumption

\begin{tabular}{|c|c|c|c|c|}
\hline Material & $\begin{array}{l}\text { Energy } \\
{[\mathrm{MJ}]}\end{array}$ & $\begin{array}{l}\mathrm{CO}_{2} \mathrm{e} \\
{[t]}\end{array}$ & $\begin{array}{l}\text { Virgin } \\
\text { aggregates [t] }\end{array}$ & $\begin{array}{l}\text { RAP } \\
{[t]}\end{array}$ \\
\hline \multicolumn{5}{|l|}{ Surface Layer } \\
\hline AC $5 \mathrm{DSH}-\mathrm{V}$ & 623.623 & 0.0442 & 0.9370 & 0.0 \\
\hline \multicolumn{5}{|l|}{ Sub Base } \\
\hline AC 32 TS & 506.701 & 0.0366 & 0.6734 & 0.2886 \\
\hline \multicolumn{5}{|l|}{ Base } \\
\hline $\begin{array}{l}\text { Stabilized soils for filling } \\
\text { and sub-base layers }\end{array}$ & 8.92 & 33.8 & 1.0 & 0.0 \\
\hline \multicolumn{5}{|l|}{ Bitumen Emulsion } \\
\hline Emulsion $60 \%$ & 2912.0 & 0.1708 & 0.0 & 0.0 \\
\hline \multicolumn{5}{|l|}{ Removed Material } \\
\hline Spoil for landfill & 306.0 & 0.0122 & 0.0 & 0.0 \\
\hline
\end{tabular}

e) Output

For the input data above, later referred to as scenario 0, the distribution of the energy and $\mathrm{CO}_{2}$ emissions of the different life-cycle stages are illustrated in Graph 6-9 and Graph 6-10. The total energy consumption is 3953502 MJ, the total CO 2 e emissions are 260 tonnes, the results generated by SEVE can be seen in Appendix D. The two graphs illustrate that the share of manufacturing and raw material quarrying are the largest for both energy consumption and $\mathrm{CO}_{2} \mathrm{e}$ emissions. To generate a PDF report with tables and illustrations different scenarios have to be input into SEVE, if only one solution is examined the environmental impacts are summarized in a table. 


\section{Energy consumption}

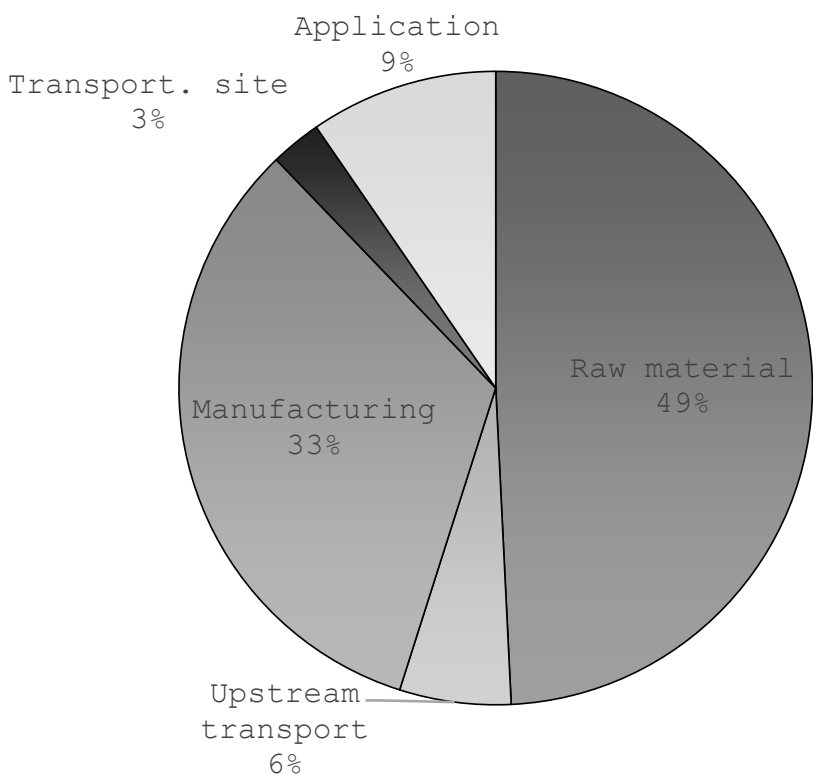

Graph 6-9: Illustration of distribution of energy consumption of life-cycle stages, SEVE

\section{$\mathrm{CO}_{2} \mathrm{e}$ emissions}

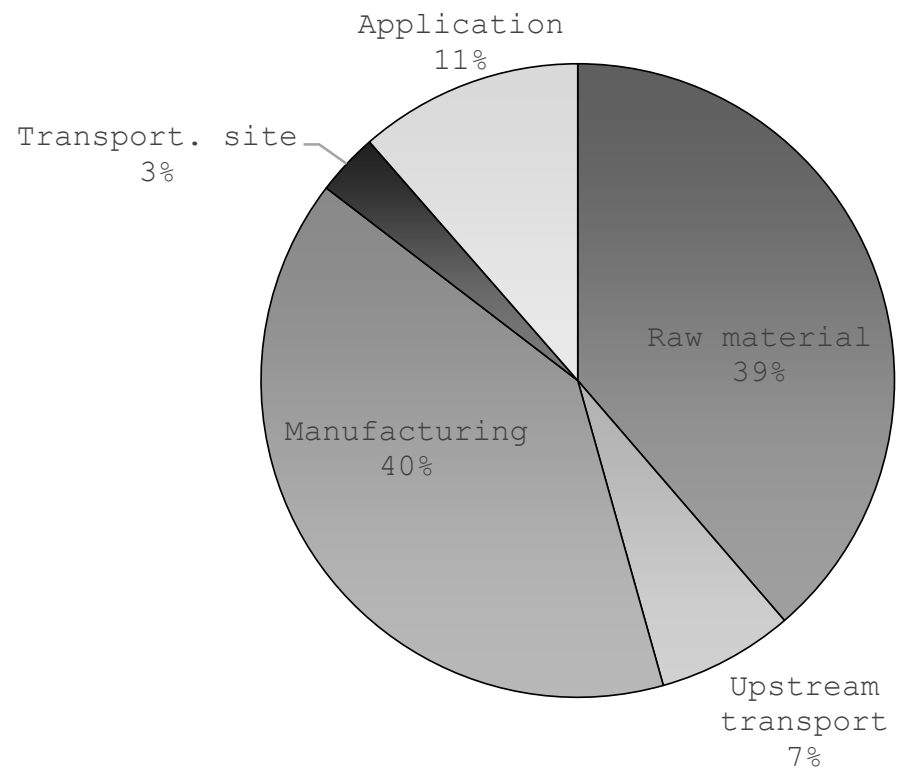

Graph 6-10: Illustration of distribution of $\mathrm{CO}_{2}$ emissions of life-cycle stages, SEVE 
f) Scenarios

In the following section two scenarios have been explored, increasing distances between material source, construction site and landfill and the impact of the construction time on the environmental effect of the project. The report for the first scenario generated by SEVE for the comparison of the output of the various options has been enclosed in Appendix $D$ for the second scenario a table summarizing the results has been included.

Scenario 1 - Distances

For the first scenario different distances have been explored from $10 \mathrm{~km}$ to $50 \mathrm{~km}$ between the material source and the construction site and from construction site to landfill site. The report from SEVE has been enclosed as an example for how the report is structured in Appendix D. The results illustrate that the distance has only an impact on the factor 'haul to construction site' and that it is linear. All other values remain the same with an increase in distances. Graph 6-11 and Graph 6-12 illustrate the effect of a change of the distances between material source - construction site - landfill. 


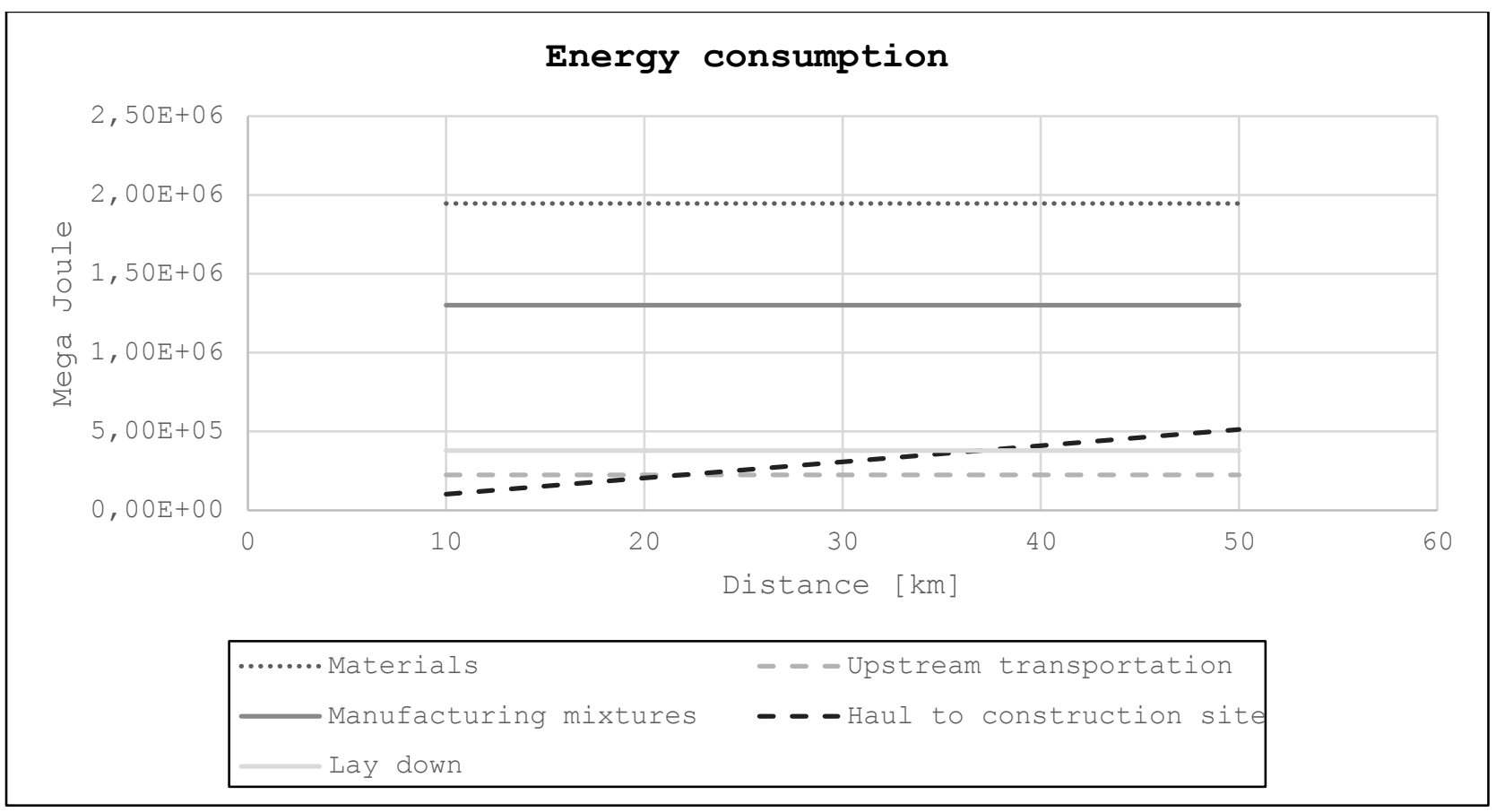

Graph 6-11: Illustration of impact of distances on energy consumption, SEVE

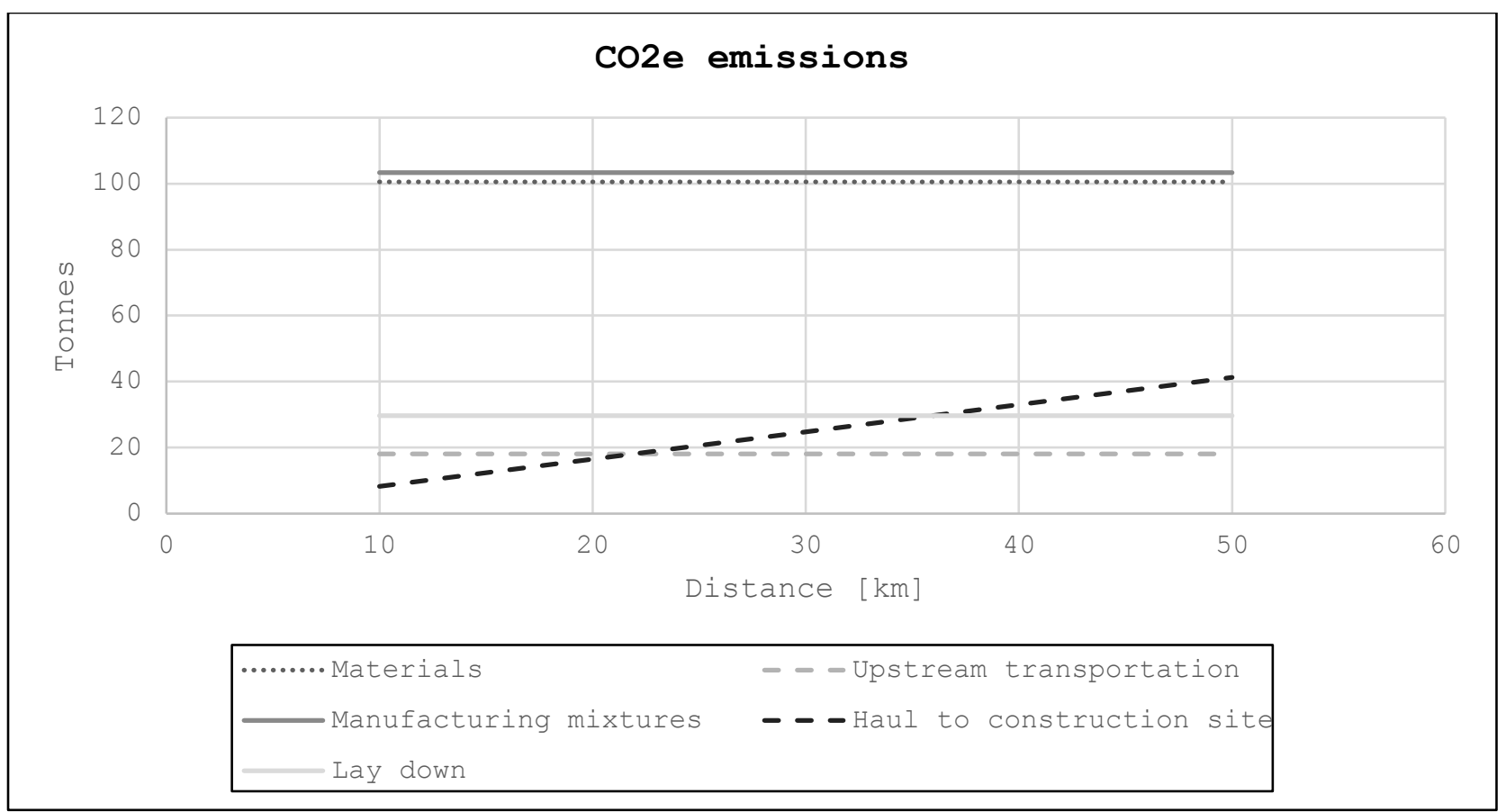

Graph 6-12: Illustration of impact of distances on $\mathrm{CO}_{2}$ e emissions, SEVE 
Scenario 2 - Construction time

For a second scenario the impact on the environment of the operation time of the equipment used and therefore the construction time has been examined. In this scenario the operation time of the equipment increases gradually by $50 \%$, from the initial case (100 \%) to 250 operation time. A linear increase of the construction time results in a linear increase of the 'lay down' stage of the life-cycle for both categories, energy consumption and $\mathrm{CO}_{2} \mathrm{e}$ emissions. All other categories remain constant as can be seen in Graph 6-13 and Graph 6-14. The tables of the report generated by SEVE have been enclosed in the Appendix.

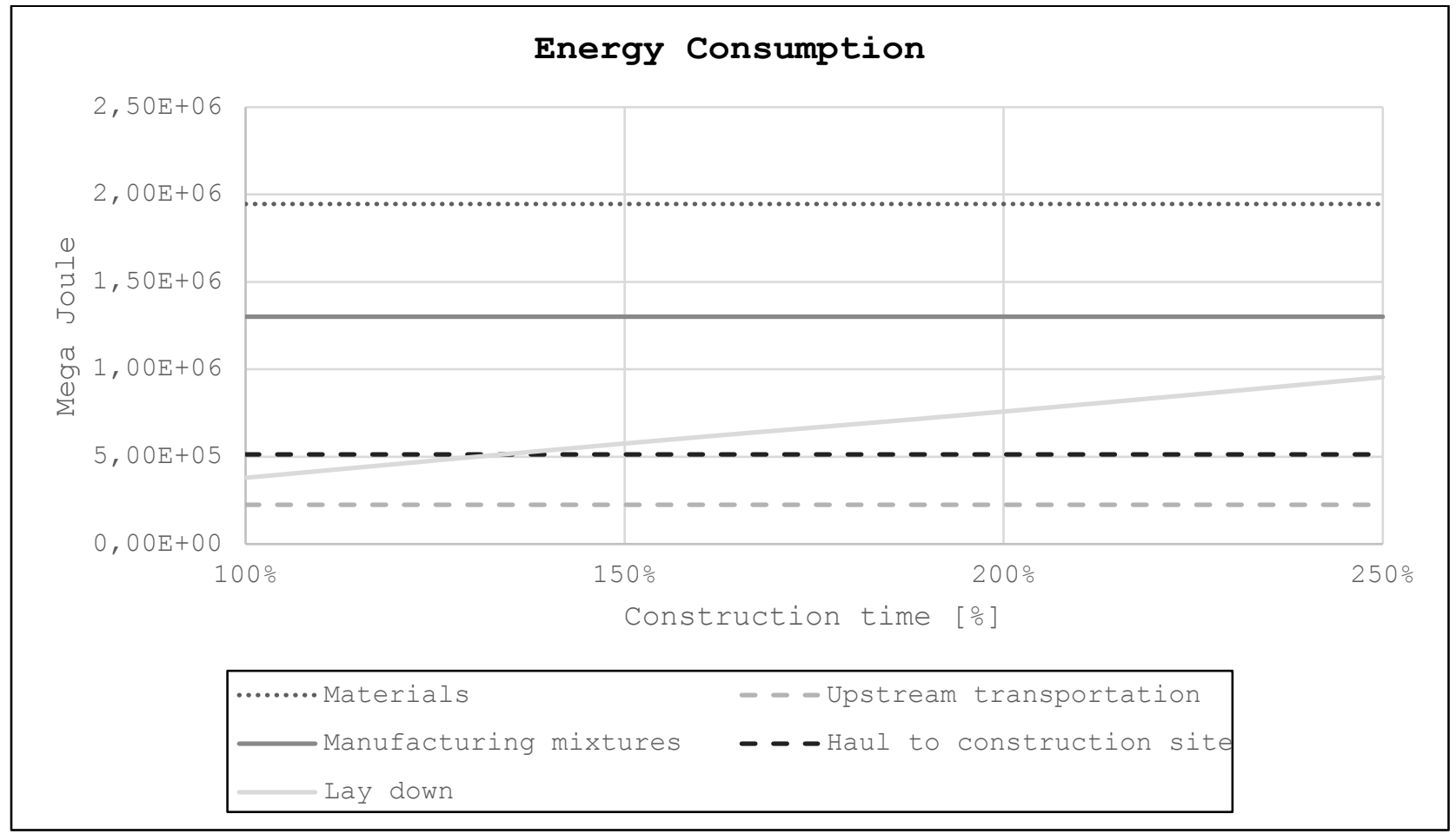

Graph 6-13: Illustration of impact of construction time on energy consumption, SEVE 


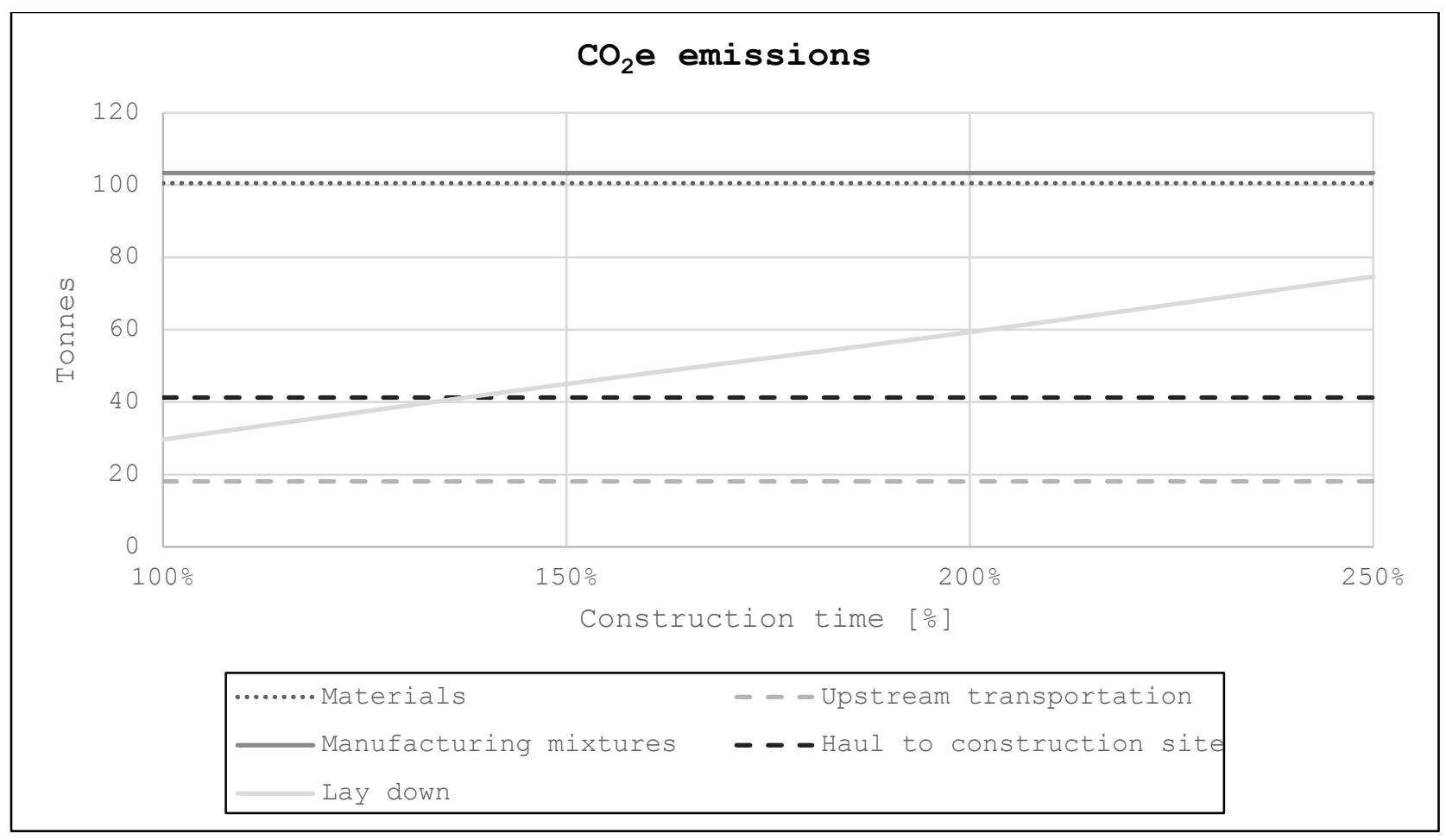

Graph 6-14: Illustration of impact of construction time on CO2e emissions, SEVE

\section{4 .2 Summary}

The structure of the French assessment tool SEVE with its different levels of access allows a high level of control over the input and therefor a high level of transparency regarding the output. However, this also hinders every day work of the engineer using the tool regularly. The software generates a detailed report with different types of result presentation. The way the individual projects are built is very detailed and structured in various sub categories which allows on the one hand to enter different options at different input stages but on the other hand complicates the input process. The fact that the tool is an online tool is helpful to share projects within a company. However, at the same time the application depends on the availability and quality of the internet connection. 


\subsection{Comparison of assessment tools}

To set the results obtained by the assessment tools into context and to illustrate their amount compared to other values, different emissions have been compiled in the following table (Table 6-14), first the results obtained for the project by the three assessment tools applied in this thesis and then the emissions of a one-way flight from Frankfurt to Toronto and the emissions produced by Germany in 2015 and Canada in 2014 respectively have been compiled.

Table 6-14: Comparison of different emissions

\begin{tabular}{|l|r|}
\hline Source & Emissions in $\mathbf{k g C O}_{\mathbf{2}} \mathbf{e}$ \\
\hline asPECT (GB) & 966,066 \\
\hline Athena Pavement LCA (CA) & $1,150,933$ \\
\hline SEVE (F) & 259,890 \\
\hline Flight Frankfurt $\rightarrow$ Toronto & 1,200 \\
\hline Germany 2015 & $903,000,000,000$ \\
\hline Canada 2014 & $732,000,000,000$ \\
\hline
\end{tabular}

The results obtained by the tools vary significantly, especially the values calculated by the French tool SEVE diverge from the other results. This might be due to the fact that SEVE is not considering the whole life-cycle opposed to the other two tools. In order to determine the significance of this difference other projects as well as input data should be compared.

To compare the tools in relation to their input, output and structure a list of aspects have been considered and compiled in Table 6-15. The Swiss method NISTRA has been developed for a different stage of the lifecycle of the road, the planning stage and not the construction stage.

15 Calculated with: https://co2.myclimate.org/en/flight_calculators/new

16 Source: [67]

17 Source: [68] 
However, it is the only one that considers all three sustainability aspects: environment, social, economic. The application of NISTRA cannot be evaluated here, as the tool could not be applied in the course of the thesis. Nevertheless, the concept is comprehensive and allows for an adaptation to the size of project and input data available.

Table 6-15: Comparison of assessment tools

\begin{tabular}{|c|c|c|c|c|}
\hline Category & NISTRA & asPECT & ATHENA & SEVE \\
\hline Type & Excel tool & Software & $\begin{array}{l}\text { Online tool } \\
\text { and software }\end{array}$ & Online tool \\
\hline Input & $\begin{array}{l}\text { Different } \\
\text { options for } \\
\text { alignment }\end{array}$ & $\begin{array}{l}\text { Emissions of } \\
\text { materials, } \\
\text { production \& } \\
\text { consumption } \\
\text { of plant, } \\
\text { quantity of } \\
\text { materials } \\
\text { used }\end{array}$ & $\begin{array}{l}\text { Structure of } \\
\text { road, details } \\
\text { about project } \\
\text { (e.g. price, } \\
\text { equipment) }\end{array}$ & $\begin{array}{l}\text { Different options } \\
\text { from responses to } \\
\text { call for tender }\end{array}$ \\
\hline $\begin{array}{l}\text { Necessary } \\
\text { data }\end{array}$ & $\begin{array}{l}\text { Detailed } \\
\text { knowledge } \\
\text { about impact } \\
\text { of project on } \\
\text { surrounding }\end{array}$ & $\begin{array}{l}\text { Data about } \\
\text { production \& } \\
\text { consumption } \\
\text { of asphalt } \\
\text { plant, } \\
\text { emissions of } \\
\text { aggregates }\end{array}$ & $\begin{array}{l}\text { General } \\
\text { information } \\
\text { about project }\end{array}$ & $\begin{array}{l}\text { Data about } \\
\text { environmental } \\
\text { impact of } \\
\text { materials used, } \\
\text { level of detail } \\
\text { depends on type of } \\
\text { access }\end{array}$ \\
\hline Result & $\begin{array}{l}\text { Report with } \\
\text { three } \\
\text { categories: } \\
\text { monetary } \\
\text { scheme, grade } \\
\text { scheme, } \\
\text { verbal } \\
\text { evaluation }\end{array}$ & $\begin{array}{l}\text { Emissions in } \\
\mathrm{kgCO} 2 \mathrm{e}\end{array}$ & $\begin{array}{l}\text { Report with } \\
\text { different } \\
\text { types of } \\
\text { environmental } \\
\text { indicators }\end{array}$ & $\begin{array}{l}\text { Energy consumption } \\
\text { Greenhouse Gas } \\
\text { Emissions } \\
\text { Natural resources } \\
\text { savings } \\
\text { RAP content }\end{array}$ \\
\hline $\begin{array}{l}\text { Key } \\
\text { documents }\end{array}$ & $\begin{array}{llll}\text { SN } & 641 & 800 & - \\
\text { SN } & 641 & 820 & \end{array}$ & $\begin{array}{ll}\text { ISO } & 14040 \\
\text { ISO } & 14044\end{array}$ & $\begin{array}{l}\text { LCA concept } \\
(\text { ISO 14040) }\end{array}$ & $\begin{array}{l}\text { ISO } 14040 \\
\text { NF } \\
P 01-010\end{array}$ \\
\hline $\begin{array}{l}\text { Considered } \\
\text { Aspects }\end{array}$ & $\begin{array}{l}\text { Environment, } \\
\text { Economy, } \\
\text { Social }\end{array}$ & Environment & Environment & Environment \\
\hline
\end{tabular}


The British tool asPECT requires a relatively detailed knowledge about the emissions generated by the quarrying of the raw materials as well as the production of the asphalt layers. However, as it is related to government regulations for the mandatory reporting of emissions of companies British companies might be able to provide the necessary data available more easily. Compared to the other tools asPACT requires the highest level of detail for the input data and seems to generate the least differentiated results.

The Canadian tool Athena Pavement LCA is structured simple and clear and is easy to use, for the input data required is readily accessible such as the thickness and material of the road structure layers. The output is highly differentiated, however compared to the other tools the methodology of the tool is less transparent and the results obtained are not immediately comprehensible.

SEVE, the French tool has a sophisticated structure with different types of access leading to a hierarchy among the users of the tool. The different access types allow for a high level of control of the input data and therefore a high transparency of the output. However, this concept also hinders a fast input and increases the time needed to obtain results. 


\section{$7 \quad$ Outlook}

The analysis and comparison of the tools considered in the scope of this thesis illustrate the limits of their application on a road construction project in Germany. Each of those assessment tool has been specifically developed for the needs and goals of the local user and target group and is working based on the national standards and guidelines. Even though numerous international and European standards and guidelines have been developed they are not able to cover the German circumstances and the requirements of the market.

For the application in Germany in addition to an assessment tool, indicator catalogues and databases with reference values specific to the requirements of a road construction and rehabilitation project should be established. This could either be accomplished by utilising the most appropriate aspects of the resources and methodologies of already existing tools and adapting them to the German requirements or by developing a new tailor made concept. To develop a pragmatically solution a compromise between those options would be most suitable. Taking into account the different needs of the German infrastructure construction industry it would be reasonable to integrate the most suitable and applicable aspects of the tools and concepts already existing in other countries.

Such a solution should be based on for instance the EU-project LCE4ROADS which is doing research related to the sustainability evaluation of roads and infrastructures since 2013 and in addition on the project EDGAR (Evaluation and Decision Process for Greener Asphalt Roads) investigating a harmonized evaluation of bituminous construction projects.

A detailed review of these concepts and methodologies would be beyond the scope of this thesis, however, some aspects of them could be of high interest for the German situation with its growing number of rehabilitation projects as opposed to new constructions which the 
evaluated tools have been developed for and the above mentioned projects are predominately concerned with.

As has already been mentioned LCE4ROADS published in 2016 a catalogue of 21 indicators which consists in addition to the environmental considerations of social and economic aspects. This list of indicators has been enclosed in Appendix A. Based on these Sustainability Performance Indicators (SPI) indicators suitable for the application in Germany could be determined. [28]

The aim of the EDGAR project has been the development of a manageable set of indicators that are meaningful and relevant to the situation at hand and not too time- and data-consuming. Their recommended Product Category Rules (PCRs) for bituminous materials and technologies has also been enclosed in Appendix A. EDGAR includes in addition to the indicators listed in the European Standard EN 15804 (see Section 4.2) socio-economic aspects of the life-cycle of a product. Based on these indicators aspects about the asphalt mixture could be included in a set of indicators for Germany • [41]

In addition to the indicators used for the sustainability evaluation the structure and methodology of the concept developed for the application in Germany is also of importance. PIARC, the world road association, proposes a concept where the level of detail considered by the indicators is structured hierarchically depending on the requirements of the user of the tool as well as the target group of the outcome. On the one end of the scale are detailed technical indicators considering the project on a micro-level for engineers and on the other end of the scale are simple indicators for the community examining the project on a macrolevel. An illustration of this 'Information Quality Levels' (IQL) concept can be seen in Figure 7-1. [69] 


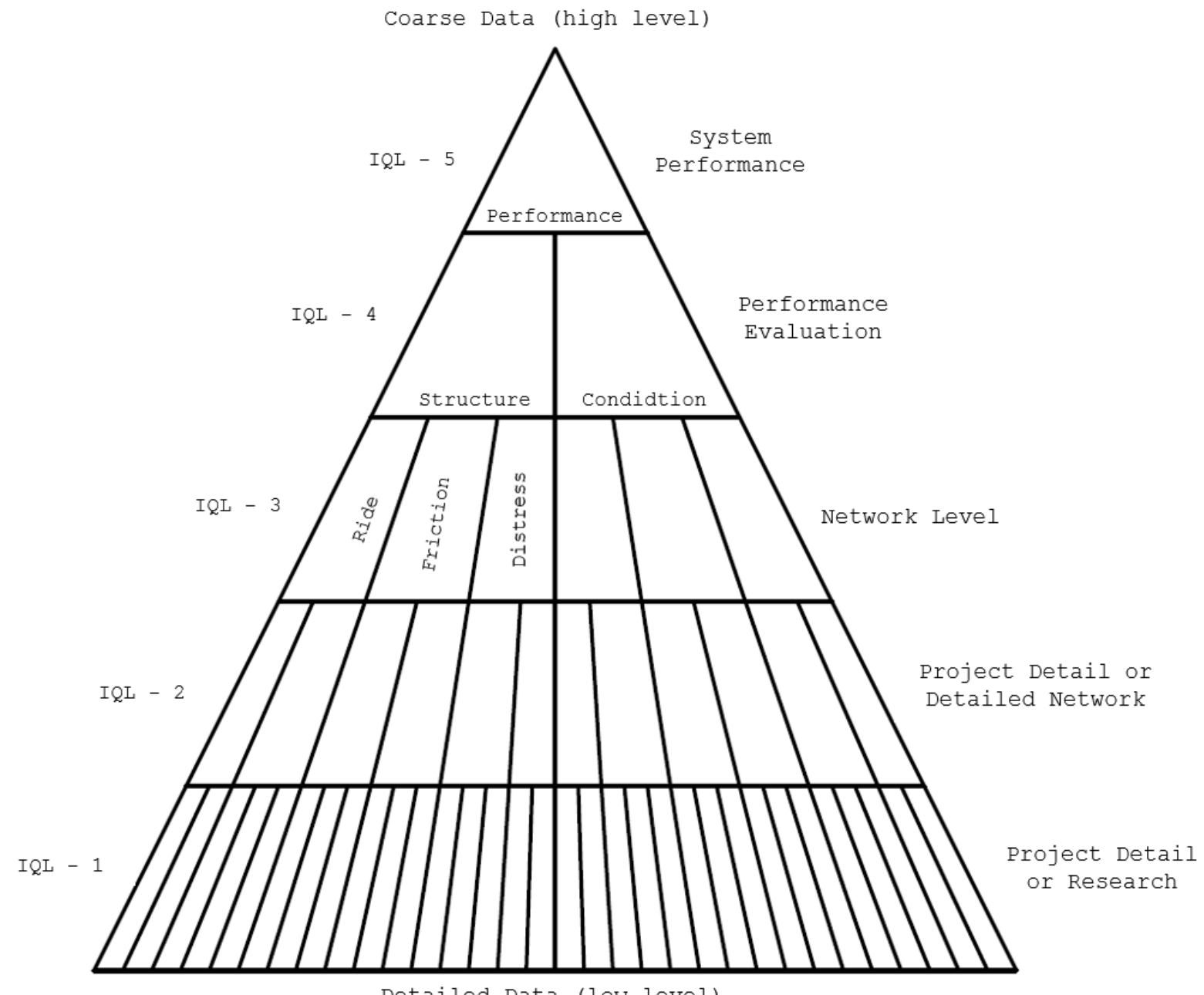

Figure 7-1: Information Quality Levels (IQL) concept [69]

A software tool based on the IQL concept could for instance have the option to choose a project size and desired level of detail according to the given situation. Based on this choice, parts or all of the input levels could then be made available to the user. This would allow the user to accommodate the time and data needed to generate the desired output appropriate to the project size. For example, an engineer using the tool to generate a report for a response to tender would want to have a more detailed output than the user would need for a public discussion in a community. 


\subsection{Suggestions for indicators}

Based on the indicators in Appendix A a catalogue of possible sustainability indicators for Germany has been composed (Table 7-1). The listed indicators in Table 7-1 have been chosen based on their applicability to a rehabilitation project. In addition to the environmental indicators from EN 15804, economic and social aspects should also be considered. However, due to the generally small scale of rehabilitation projects and the limited variations in terms of what is going to be built the number of economic and social aspects is limited. The two economic indicators $(15,16)$ listed here are the reduction of the life-cycle cost of the project and the reduction of user delay either caused by a poor road condition or mainly due to the actual construction works. High user delay could be at cost of the national economy.

Social aspects that could be considered for rehabilitation projects are for instance the health and safety for the road workers, the road user or local residents. The health and safety of road workers could be endangered by toxic material components or emissions during construction works. For users highly damaged roads and for both, users and residents factors such as traffic noise could lead to negative medical effects. 
Table 7-1: Suggested Indicators for Germany

\begin{tabular}{|c|c|c|}
\hline Category & \multicolumn{2}{|c|}{ Indicator } \\
\hline \multirow{14}{*}{ 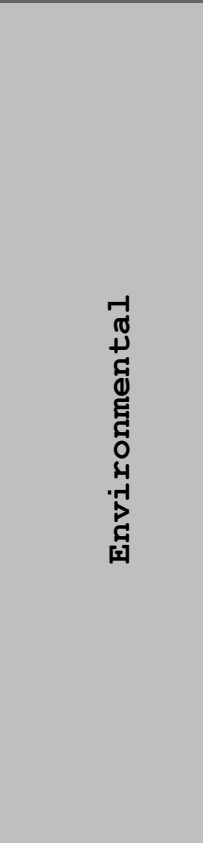 } & 1 & Primary waste consumption \\
\hline & 2 & Secondary materials used \\
\hline & 3 & Materials to be reused and recycled \\
\hline & 4 & Energy demand \\
\hline & 5 & Waste (hazardous waste/ non-hazardous waste) \\
\hline & 6 & Global Warming Potential \\
\hline & 7 & Formation potential of tropospheric ozone \\
\hline & 8 & Depletion potential of the stratospheric ozone layer \\
\hline & 9 & Acidification potential of soil and water \\
\hline & 10 & Eutrophication potential \\
\hline & 11 & Abiotic depletion potential for non-fossil resources \\
\hline & 12 & Abiotic depletion potential for fossil resources \\
\hline & 13 & Human toxicity \\
\hline & 14 & Ecotoxicity \\
\hline 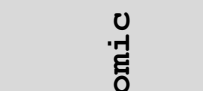 & 15 & Life-cycle cost \\
\hline $\begin{array}{l}\text { Oे } \\
\text { 国 }\end{array}$ & 16 & User delay \\
\hline & 17 & Responsible sourcing \\
\hline & 18 & Adaptation to climate change \\
\hline 검 & 19 & Traffic congestion due to maintenance activities \\
\hline ชั่ & 20 & Health \& safety for road workers (e.g. toxicity) \\
\hline & 21 & Health \& safety for road users (e.g. tyre pavement noise) \\
\hline & 22 & Health \& safety for local residents (e.g. noise, pollution) \\
\hline
\end{tabular}




\section{Conclusion}

The assessment of the tools and concepts considered and their application to the rehabilitation project of a road led to a number of conclusions. None of the tools considered could be transferred directly onto the German circumstances. However, a combination of some aspects of the NISTRA method, the Athena Pavement LCA tool and the PIARC Project would be a solid basis for a feasible sustainability assessment method of road construction and rehabilitation projects in Germany.

The NISTRA ( $\mathrm{CH}$ ) method provides a comprehensive sustainability evaluation taking into account all three pillars, environmental, social and economic to analysis of the construction project. The concept is based on three assessment methods: the cost-benefit analysis, the partial benefit analysis and descriptive indicators (Figure 6-1, Section 6.1). This allows it to evaluate non-technical and qualitative indicators, as opposed to the other methods.

Among the three tools calculating $\mathrm{CO}_{2} \mathrm{e}$ emissions Athena Pavement LCA (CAN) is the one with a straightforward and clear application and the most comprehensive results. However, to provide these characteristics the tool has to be backed by a detailed and constantly updated database. For Germany the already existing resources and structure of the database. As for Germany the already existing resource database ÖKOBAUDAT could function as a foundation, but would require the inclusion of further categories and data related to the road construction sector.

Based on the above findings there seems to be a correlation between the amount of data necessary as input and the size and detail of the database that comes with the tool. A large database requires less input to generate a meaningful result as can be seen by the Canadian tool, a smaller database requires more detail in terms of the input to generate a comparable result such as, for instance, with the British tool. 
In addition to the data structure of a tool the method of input is essential. A possible method of input for a proposed German concept would be the Information Quality Level method (Figure 7-1) as described in the PIARC project. This would allow for it to be applied to different purposes and different users.

A tool with such a variable structure could accommodate the different types of construction projects typical for Germany. This would result in an easier and more user-friendly tool to evaluate the sustainability of a project according to the needs of the target group and would therefore promote the overall goal of more sustainable road constructions. 


\section{Appendices}

Page

A Lists of Sustainability Indicators

Sustainability performance indicators for roads structures Swiss Target System Catalogue of Indicators

Indicator set for EU-Project EDGAR, 2008

B Results asPECT

Scenario 1 to 6

C Results Athena Pavement ICA

Scenario 0 to 2

D Results SEVE

108

Scenario 0 to 2

E CD

(1) Report SEVE: Scenario 1

(2) Handbook NISTRA

(3) Guidance asPECT

(4) Protocol asPECT

(5) User Manual asPECT

(6) User Guide Athena Pavement LCA

(7) Manual SEVE 


\section{A Sustainability Indicators}

Sustainability performance indicators for road structures [28]

Table 8-1: Sustainability performance indicators for road structures, CEN/TC WI: 2016 [28]

\begin{tabular}{|c|c|c|c|}
\hline $\begin{array}{c}\text { Sustainability } \\
\text { Pillar }\end{array}$ & & & SPI \\
\hline \multirow{14}{*}{ 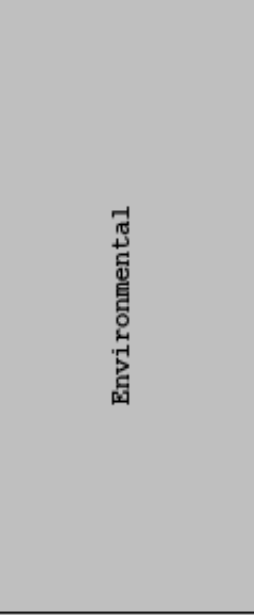 } & \multirow{14}{*}{ 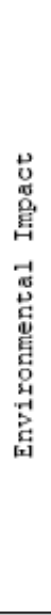 } & 1 & Primary materials consumption \\
\hline & & 2 & Secondary materials used \\
\hline & & 3 & Materials to be reused or recycled \\
\hline & & 4 & Energy demand (use of renewable energy sources/ non renewable energy sources) \\
\hline & & 5 & Waste (hazardous waste/ non-hazardous waste/ radioactive waste) \\
\hline & & 6 & Global Warming Potential \\
\hline & & 7 & Formation potential of tropospheric ozone \\
\hline & & 8 & Depletion potential of the stratospheric ozone layer \\
\hline & & 9 & Acidification potential of soil and water \\
\hline & & 10 & Eutrophication potential \\
\hline & & 11 & Abiotic depletion potential (ADP-elements) for non-fossil resources \\
\hline & & 12 & Abiotic depletion potential (ADP-fossil fuels) for fossil resources \\
\hline & & 13 & Human toxicity \\
\hline & & 14 & Ecotoxicity \\
\hline 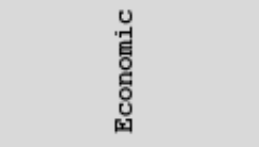 & $\begin{array}{l}\vec{n} \\
\text { o } \\
0\end{array}$ & 15 & Whole life cost \\
\hline \multirow{6}{*}{ 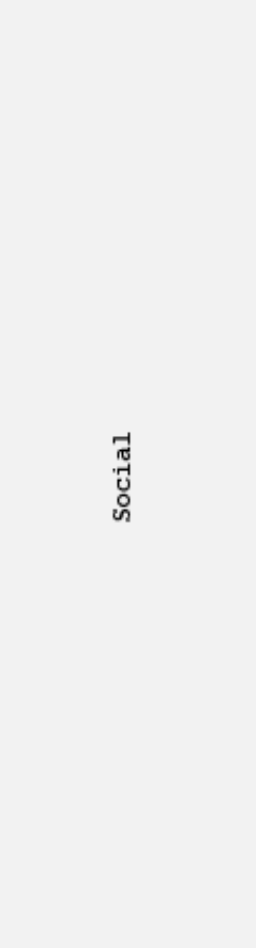 } & $\begin{array}{l}\text { 岀 } \\
\text { ○ } \\
\text { 岁 } \\
\text { O }\end{array}$ & 16 & Comfort index \\
\hline & $\begin{array}{l}\text { 总 } \\
\text { 岃 } \\
\text { o } \\
\text { in }\end{array}$ & 17 & Safety audits \& safety inspections \\
\hline & 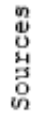 & 18 & Responsible sourcing \\
\hline & 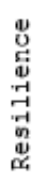 & 19 & Adaptation to climate change \\
\hline & 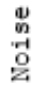 & 20 & Tyre-pavement noise \\
\hline & 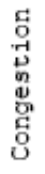 & 21 & Traffic congestion due to maintenance activities \\
\hline
\end{tabular}


Swiss Target System Catalogue of Indicators [43]

Table 8-2: Swiss Target System Catalogue of Indicators [43]

\begin{tabular}{|c|c|c|}
\hline Category & Overall Goal & Sub Goal \\
\hline \multirow{9}{*}{ 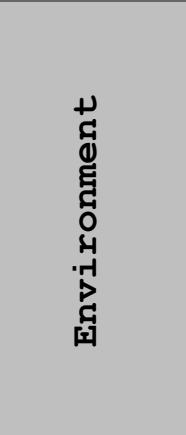 } & \multirow{5}{*}{$\begin{array}{l}\text { Reduce local, national } \\
\text { and transnational } \\
\text { environmental impacts to } \\
\text { an unobjectionable level }\end{array}$} & 1. Reduce air pollution \\
\hline & & 2. Reduce noise pollution \\
\hline & & 3. Reduce soil sealing \\
\hline & & 4. Reduce impact on landscapes and habitats \\
\hline & & 5. Reduce impact on waters \\
\hline & \multirow{2}{*}{$\begin{array}{l}\text { Reduce atmospheric } \\
\text { environmental impact }\end{array}$} & 6. Reduce impact on climate \\
\hline & & 7. Maintain ozone layer \\
\hline & \multirow[t]{2}{*}{ Save resources } & 8. Reduce non-renewable energy sources \\
\hline & & 9. Prevent use of natural resources \\
\hline \multirow{8}{*}{ 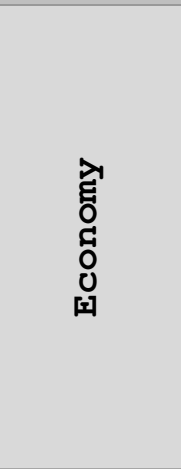 } & \multirow{3}{*}{$\begin{array}{l}\text { Create good relationship } \\
\text { between costs and } \\
\text { benefits }\end{array}$} & 10. Minimize direct annual costs of project \\
\hline & & 11. Maximize direct annual benefits of project \\
\hline & & 12. Optimize realization of project \\
\hline & \multirow[t]{4}{*}{$\begin{array}{l}\text { Optimize indirect } \\
\text { economic effects }\end{array}$} & $\begin{array}{l}\text { 13. Optimize accessibility as part of the commercial } \\
\text { location }\end{array}$ \\
\hline & & 14. Create and preserve the economic special condition \\
\hline & & 15. Support of locally balanced economic development \\
\hline & & 16. Achieve gain in know-how \\
\hline & $\begin{array}{l}\text { Achieve economic } \\
\text { viability }\end{array}$ & 17. Achieve economic viability \\
\hline \multirow{8}{*}{ 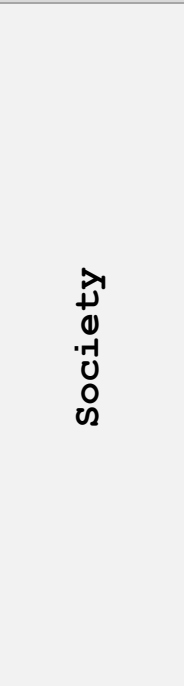 } & \multirow{2}{*}{$\begin{array}{l}\text { Provision of basic } \\
\text { supplies }\end{array}$} & 18. Provide national basic supplies \\
\hline & & $\begin{array}{l}\text { 19. Be considerate of people with an impeded access to } \\
\text { traffic and improve situation for pedestrians and } \\
\text { cyclists }\end{array}$ \\
\hline & \multirow[t]{5}{*}{ Support social solidarity } & 20. Protect human health \\
\hline & & $\begin{array}{l}\text { 21. Preserve and support independence, individuality, } \\
\text { and self-responsibility }\end{array}$ \\
\hline & & 22. Socially acceptable behaviour of involved parties \\
\hline & & $\begin{array}{l}\text { 23. Contribution to promotion of preservation and } \\
\text { rehabilitation of residential areas in urban and } \\
\text { rural areas }\end{array}$ \\
\hline & & 24. Fair distribution of costs and benefits \\
\hline & $\begin{array}{l}\text { Ensure acceptance, } \\
\text { participation, and } \\
\text { coordination }\end{array}$ & $\begin{array}{l}\text { 25. Allow involved parties suitable possibilities for } \\
\text { participation }\end{array}$ \\
\hline
\end{tabular}


Indicator set of EU-Project EDGAR, 2008

Table 8-3: Likely composition of indicators of EDGAR project [41]

\section{Environment \\ Social \\ Economic}

Based on normalisation, 2-4 indicators from:

- Resource depletion

(abiotic)

- Resource depletion (fossil fuels)

- Global Warming Potential (GWP)

- Ozone Depletion Potential (ODP)

- Acidification potential (AP)

- Eutrophication potential $(\mathrm{EP})$

- Formation potential of tropospheric ozone ( $\mathrm{POCP})$

- Abiotic depletion potential for non-fossil resources (ADP-elements)

- Abiotic depletion potential for fossil resources (ADP-fossil fuels)

- Direct resource use, waste disposal or other output flow indicators
- Health \& safety for road users (possibly incorporating 'noise')

- Health \& safety for road workers (incorporating Toxicity)

- $\quad$ Sourcing
- Life cycle cost

- User delay

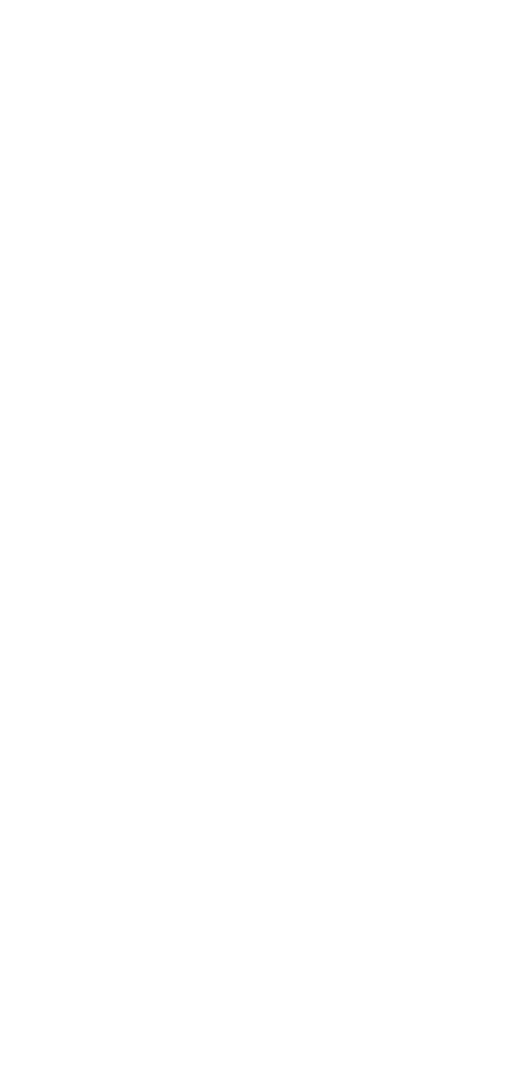




\section{B Results asPECT}

\begin{tabular}{|c|c|c|c|c|c|c|c|c|}
\hline & & & \multicolumn{3}{|c|}{ kgCO2e/t of Aggregates from Ökobaudat } & \multicolumn{3}{|c|}{ kgCO2e/t of Aggregates from Gov UK } \\
\hline & & & \multicolumn{3}{|c|}{ Scenario 0} & \multicolumn{3}{|c|}{ Scenario 1} \\
\hline & & & $\mathrm{kgCO} 2 \mathrm{e} / \mathrm{t}$ & Total kgCO2e & Total $\mathrm{kgCO} 2 \mathrm{e} / \mathrm{t}$ & $\mathrm{kgCO} 2 \mathrm{e} / \mathrm{t}$ & Total kgCO2e & Total $\mathrm{kgCO} 2 \mathrm{e} / \mathrm{t}$ \\
\hline & Step 1-3 & Material extraction and processing & 33,03 & $158.669,22$ & & 20,64 & $99.150,24$ & \\
\hline & Step 4 & Transport to plant & 3,69 & $17.731,61$ & & 3,69 & $17.731,61$ & \\
\hline & Step 5 & Asphalt production & 131,72 & $632.726,72$ & & 131,72 & $632.726,72$ & \\
\hline & Step 6 & Transport to site & 1,17 & $5.612,92$ & & 1,17 & $5.612,92$ & \\
\hline & Step 7 & Laying and compacting & 4,70 & $22.576,59$ & & 4,70 & $22.576,59$ & \\
\hline & Step 8 & Project works & 35,26 & $91.282,31$ & & 12,50 & $32.348,87$ & \\
\hline & Step 9 & Maintenance & - & - & & - & - & \\
\hline & Step 10 & End of life & 7,80 & $37.467,53$ & & 7,80 & $37.467,53$ & \\
\hline \multicolumn{3}{|c|}{ Steps 1 to 7} & & $837.317,06$ & 174,31 & & $777.798,08$ & 161,92 \\
\hline \multicolumn{3}{|c|}{ Asphalt } & & $874.784,59$ & 182,11 & & $815.265,61$ & 169,72 \\
\hline \multicolumn{3}{|c|}{ Project } & & $966.066,90$ & & & $847.614,48$ & \\
\hline \multirow[t]{6}{*}{ AC 11 DS } & & & & $284.802,16$ & 183,77 & & $255.194,59$ & 164,66 \\
\hline & & Tonnage & & $1.549,80$ & & & $1.549,80$ & \\
\hline & Step 1 to 3 & Material extraction and processing & & $73.050,62$ & & & $43.443,05$ & \\
\hline & Step 4 & Transport to plant & & $5.799,09$ & & & $5.799,09$ & \\
\hline & Step 5 & Asphalt production & & $204.141,51$ & & & $204.141,51$ & \\
\hline & Step 6 & Transport to site & & $1.810,94$ & & & $1.810,94$ & \\
\hline \multirow[t]{9}{*}{ AC 32 TS } & & & & $529.938,32$ & 162,87 & & $500.026,91$ & 153,68 \\
\hline & & Tonnage & & $3.253,73$ & & & $3.253,73$ & \\
\hline & Step 1 to 3 & Material extraction and processing & & $85.618,60$ & & & $55.707,19$ & \\
\hline & Step 4 & Transport to plant & & $11.932,53$ & & & $11.932,53$ & \\
\hline & Step 5 & Asphalt production & & $428.585,21$ & & & $428.585,21$ & \\
\hline & Step 6 & Transport to site & & $3.801,98$ & & & $3.801,98$ & \\
\hline & \multicolumn{2}{|c|}{ Heating consumption (Fuel) } & & $11.426 .757,00$ & & & $11.426 .757,00$ & \\
\hline & \multicolumn{2}{|c|}{ Nonheating consumption (Fuel) } & & $51.961,60$ & & & $51.961,60$ & \\
\hline & \multicolumn{2}{|c|}{ Nonheating consumption (Electricity) } & & $9.596 .672,80$ & & & $9.596 .672,80$ & \\
\hline \multirow[t]{6}{*}{ AC 11 DS } & & & & & 182,60 & & & 163,49 \\
\hline & \multicolumn{2}{|c|}{ Virgin Mix kg CO2e/t } & 52,81 & & & 33,70 & & \\
\hline & \multicolumn{2}{|c|}{ RAP Saving kgCO2e/t } & 5,67 & & & 5,67 & & \\
\hline & \multicolumn{2}{|c|}{ Transport kg CO2e/t } & 3,74 & & & 3,74 & & \\
\hline & \multicolumn{2}{|c|}{ Heating kg CO2e/t } & 71,42 & & & 71,42 & & \\
\hline & \multicolumn{2}{|c|}{ Non Heating kg CO2e/t } & 60,30 & & & 60,30 & & \\
\hline \multirow[t]{6}{*}{ AC 32 TS } & \multirow{2}{*}{\multicolumn{2}{|c|}{ Virgin Mix kg CO2e/t }} & & & 161,70 & & & 152,51 \\
\hline & & & 30,51 & & & 21,31 & & \\
\hline & \multicolumn{2}{|c|}{ RAP Saving kgCO2e/t } & 4,19 & & & 4,19 & & \\
\hline & \multicolumn{2}{|c|}{ Transport kg CO2e/t } & 3,67 & & & 3,67 & & \\
\hline & \multicolumn{2}{|c|}{ Heating kg CO2e/t } & 71,42 & & & 71,42 & & \\
\hline & \multicolumn{2}{|c|}{ Non Heating kg CO2e/t } & 60,30 & & & 60,30 & & \\
\hline
\end{tabular}




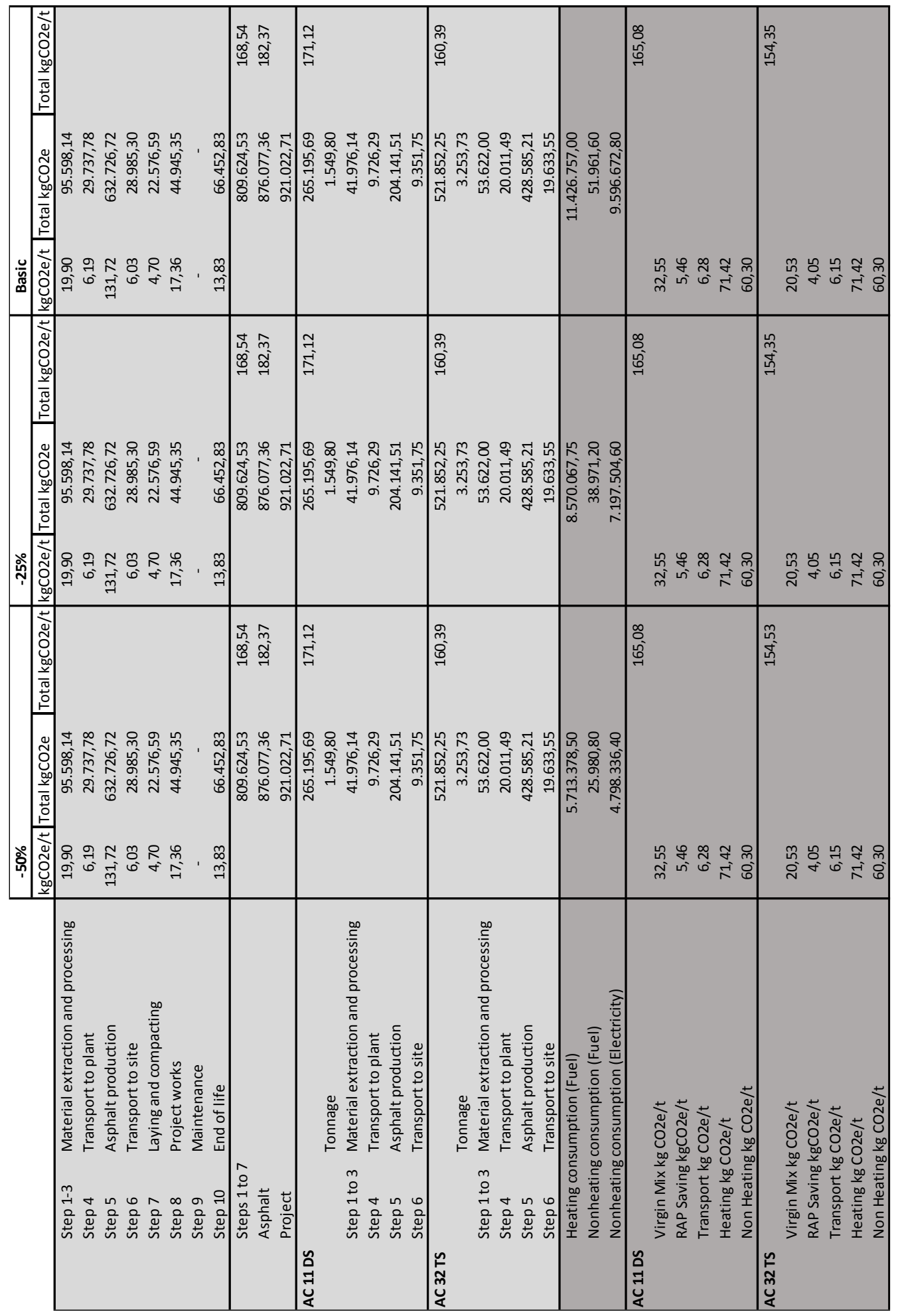




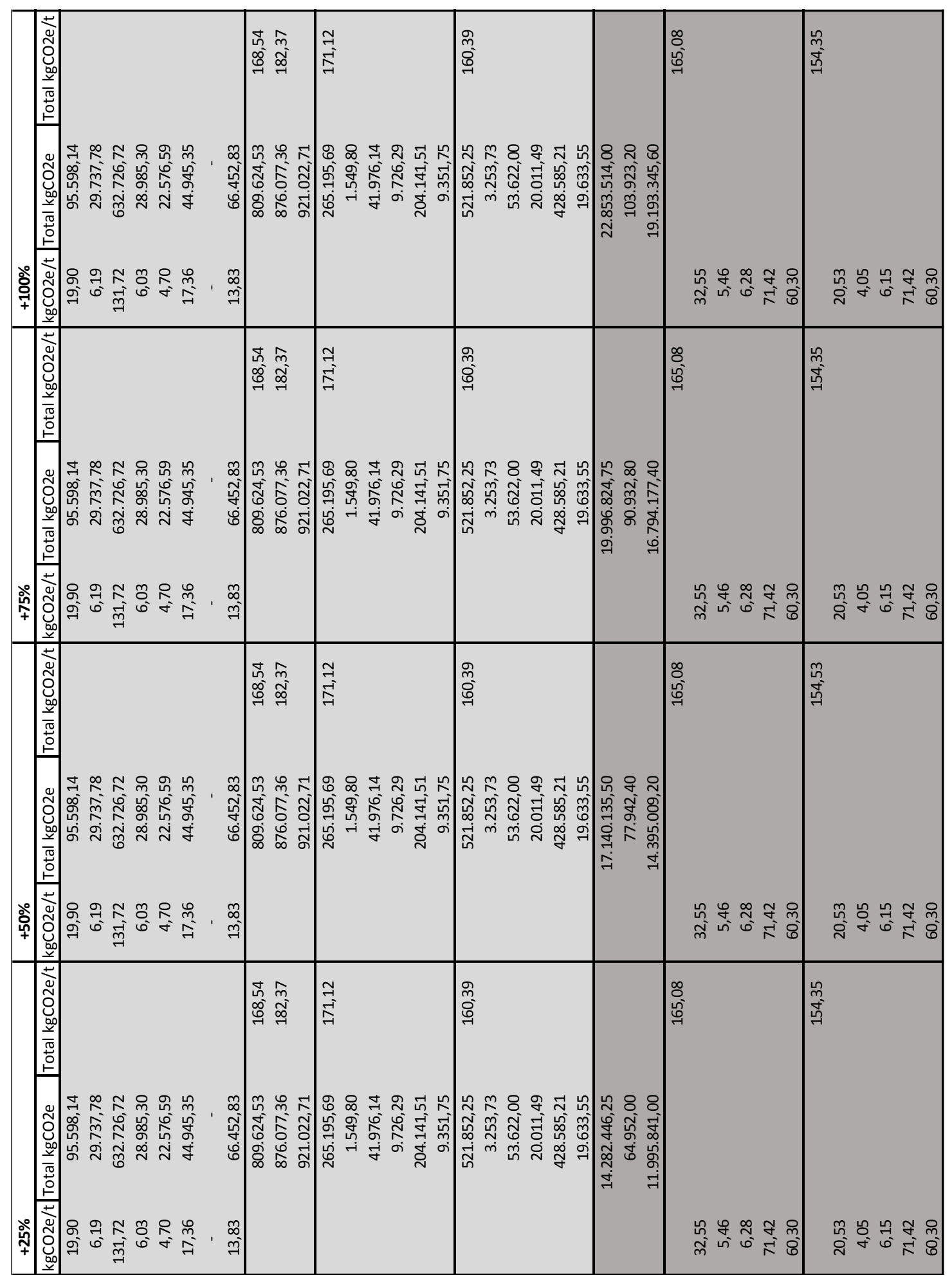




\section{Scenario 3}

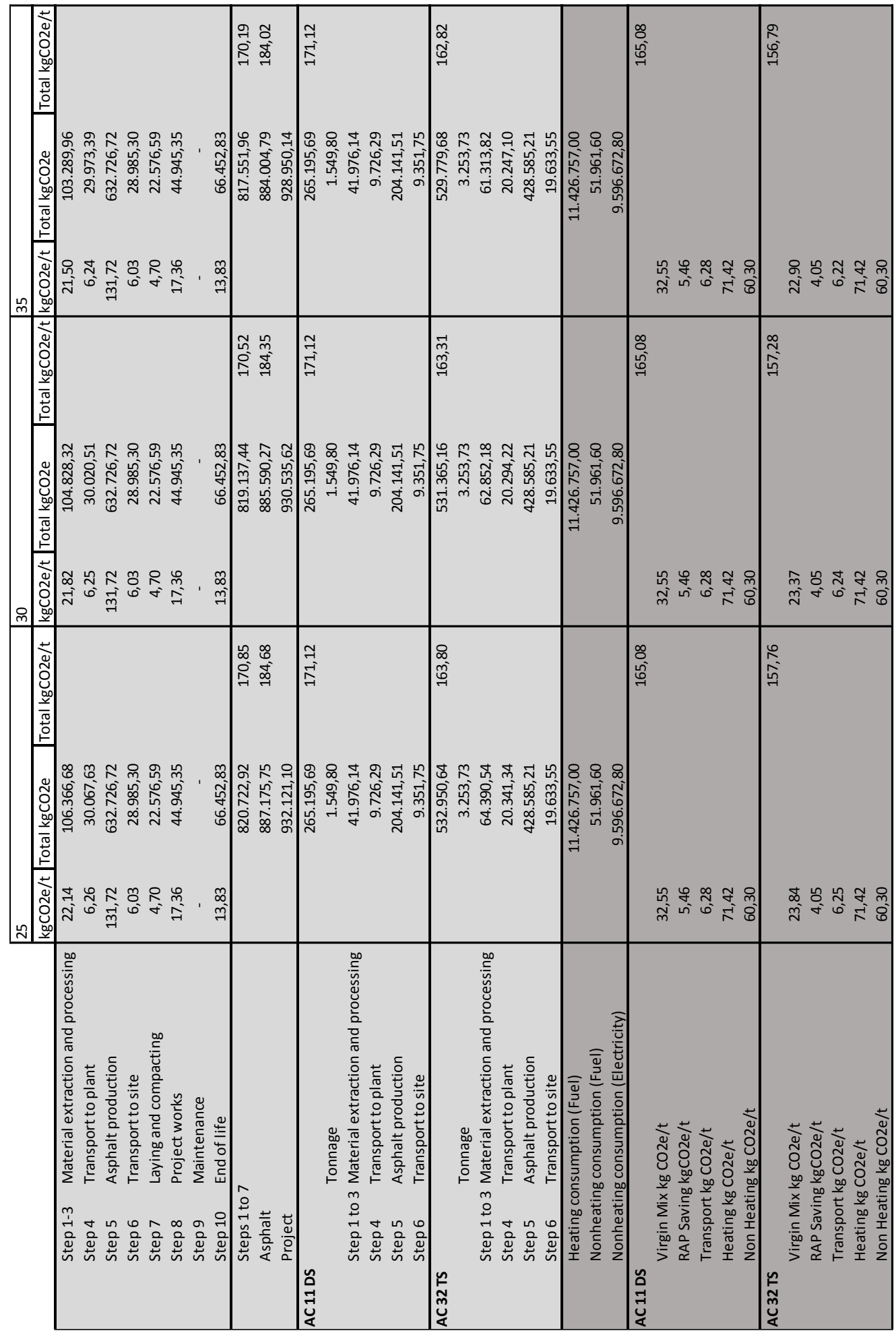




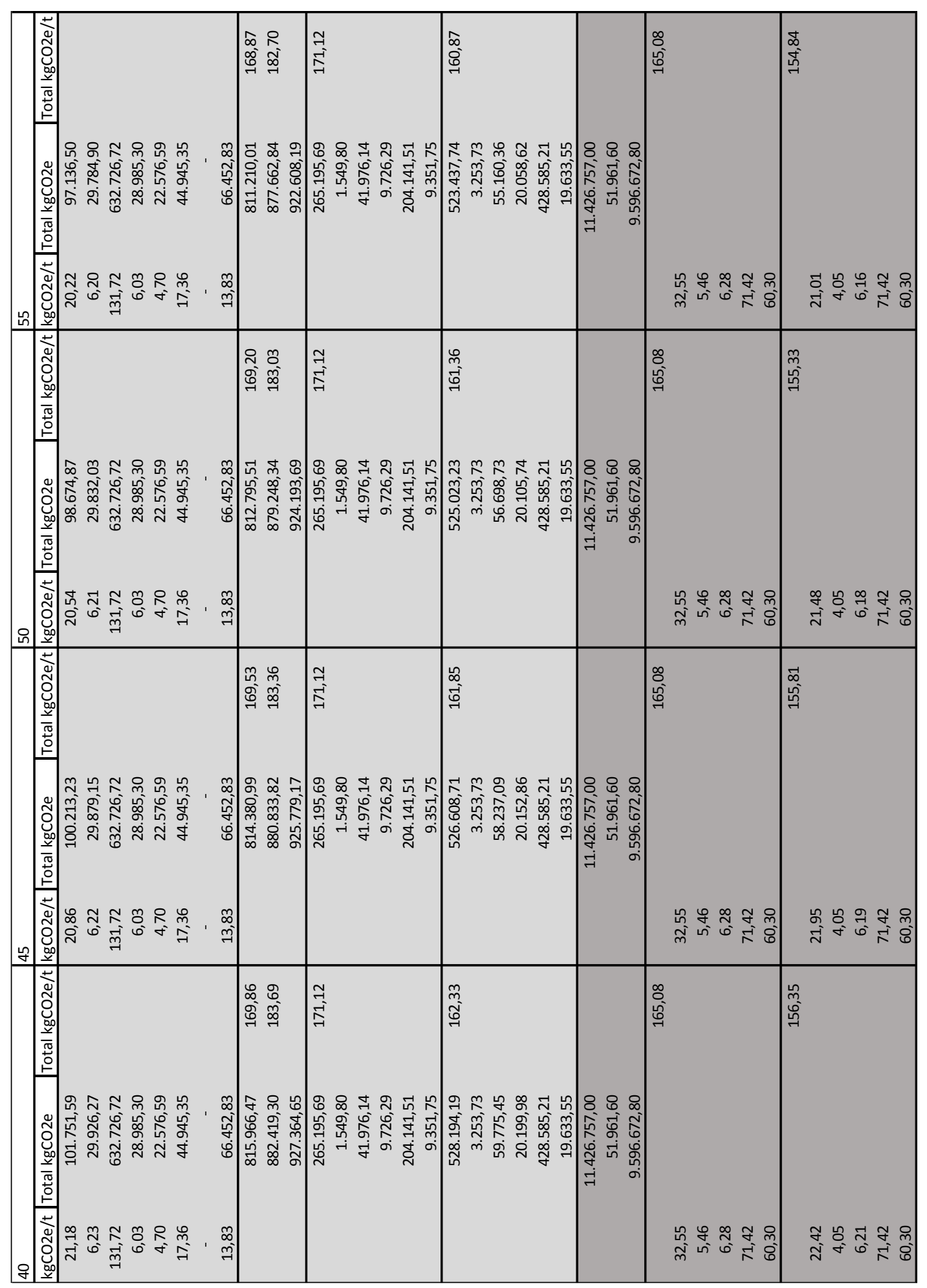




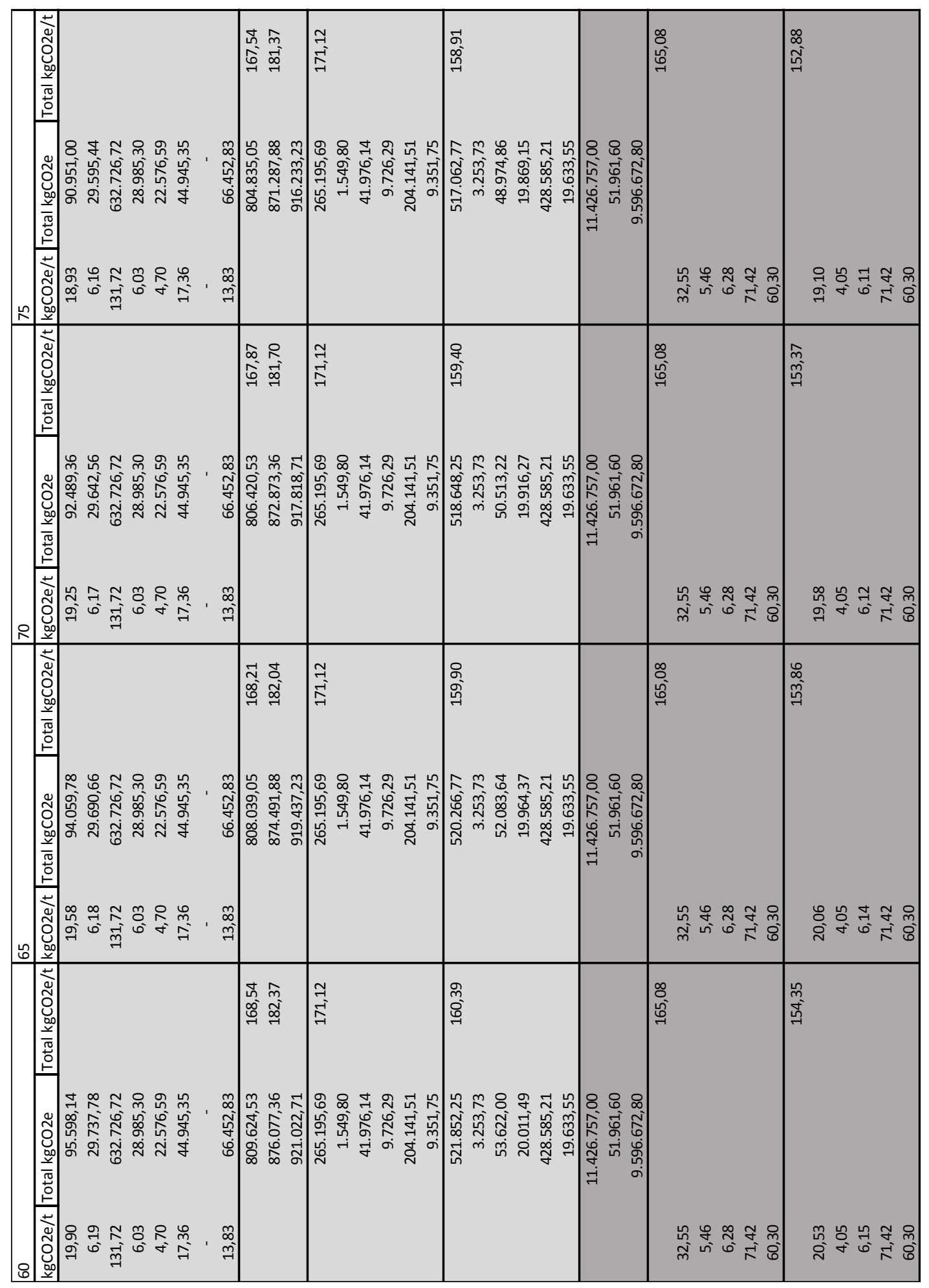




\section{Scenario 4}

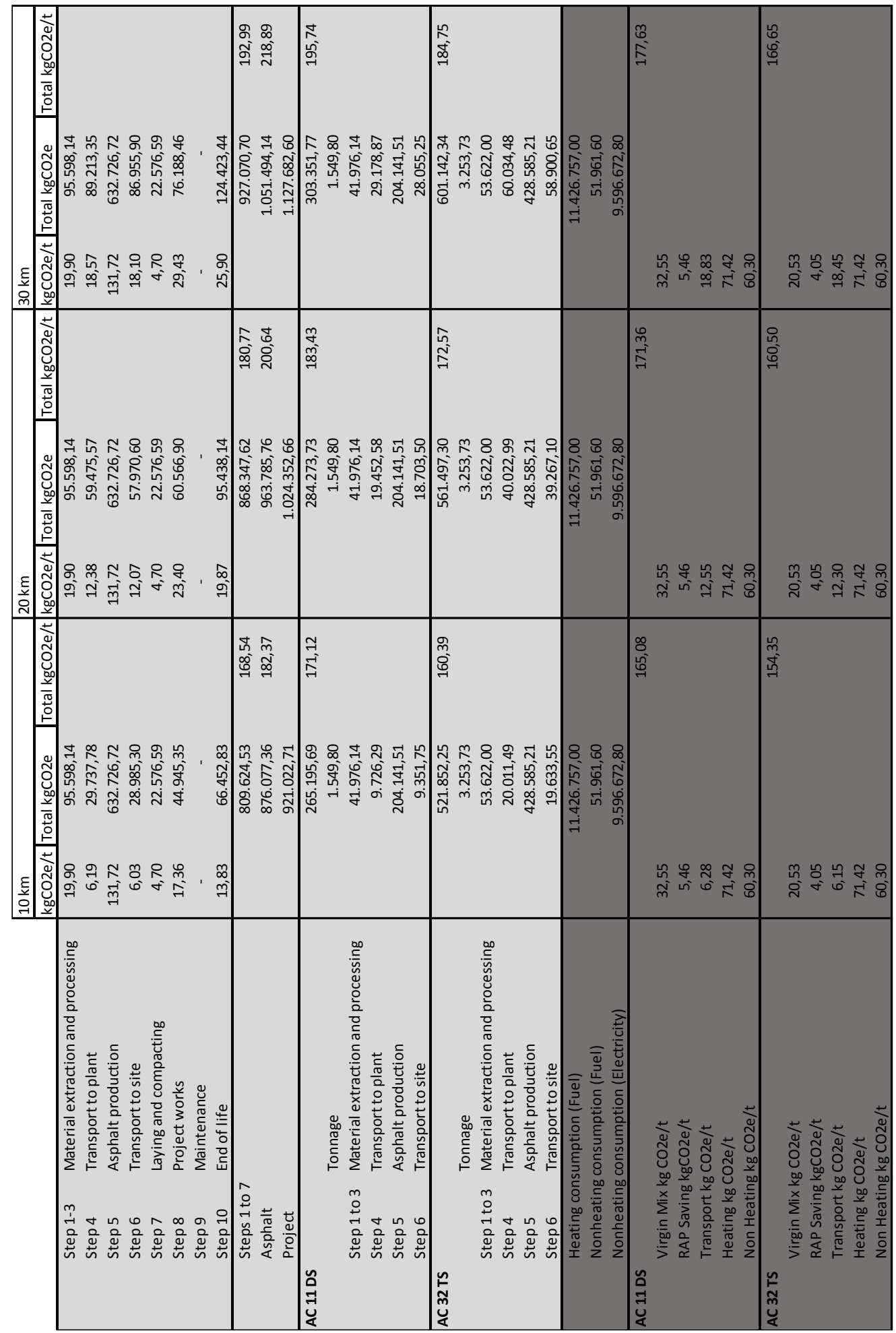




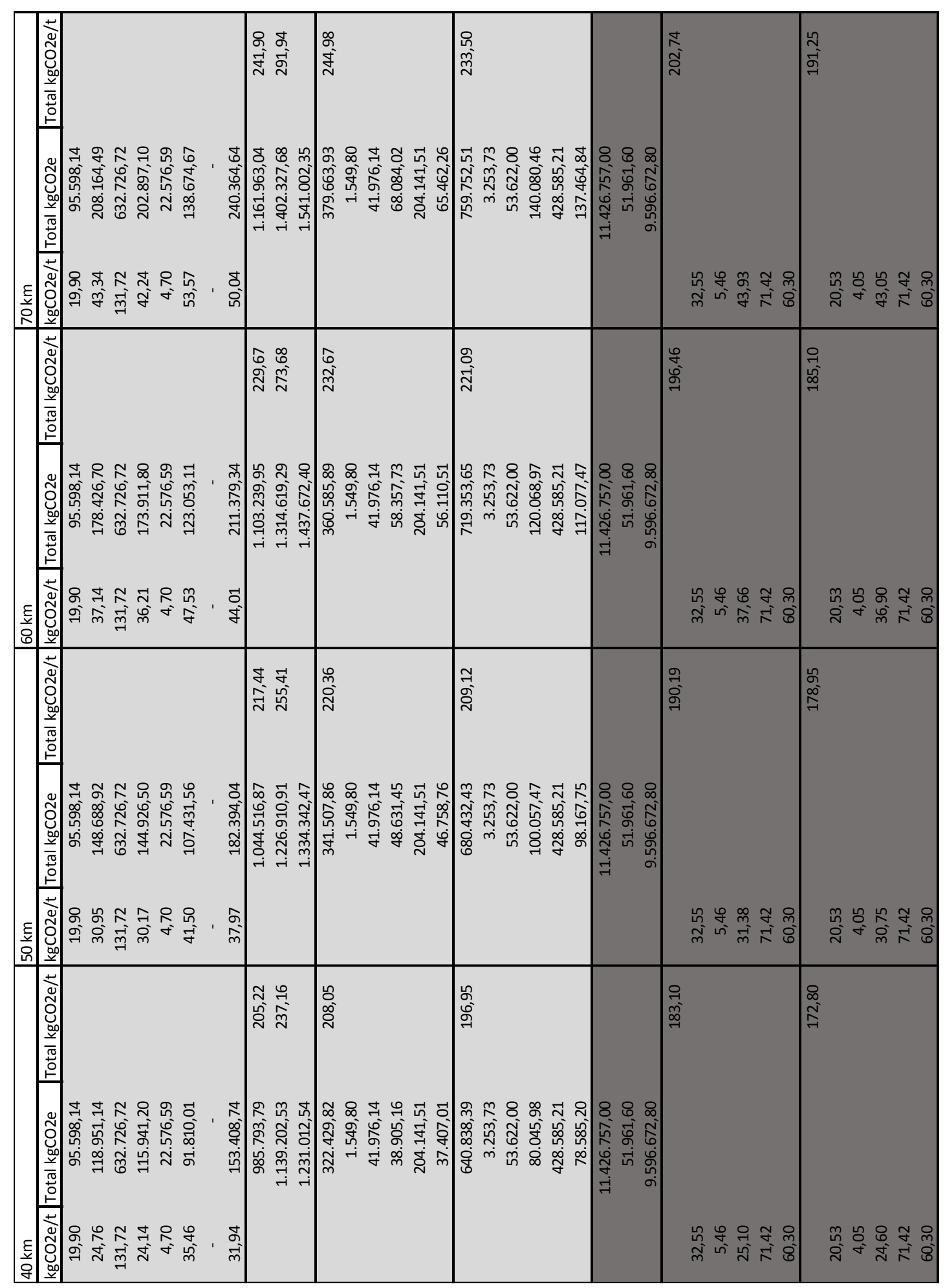




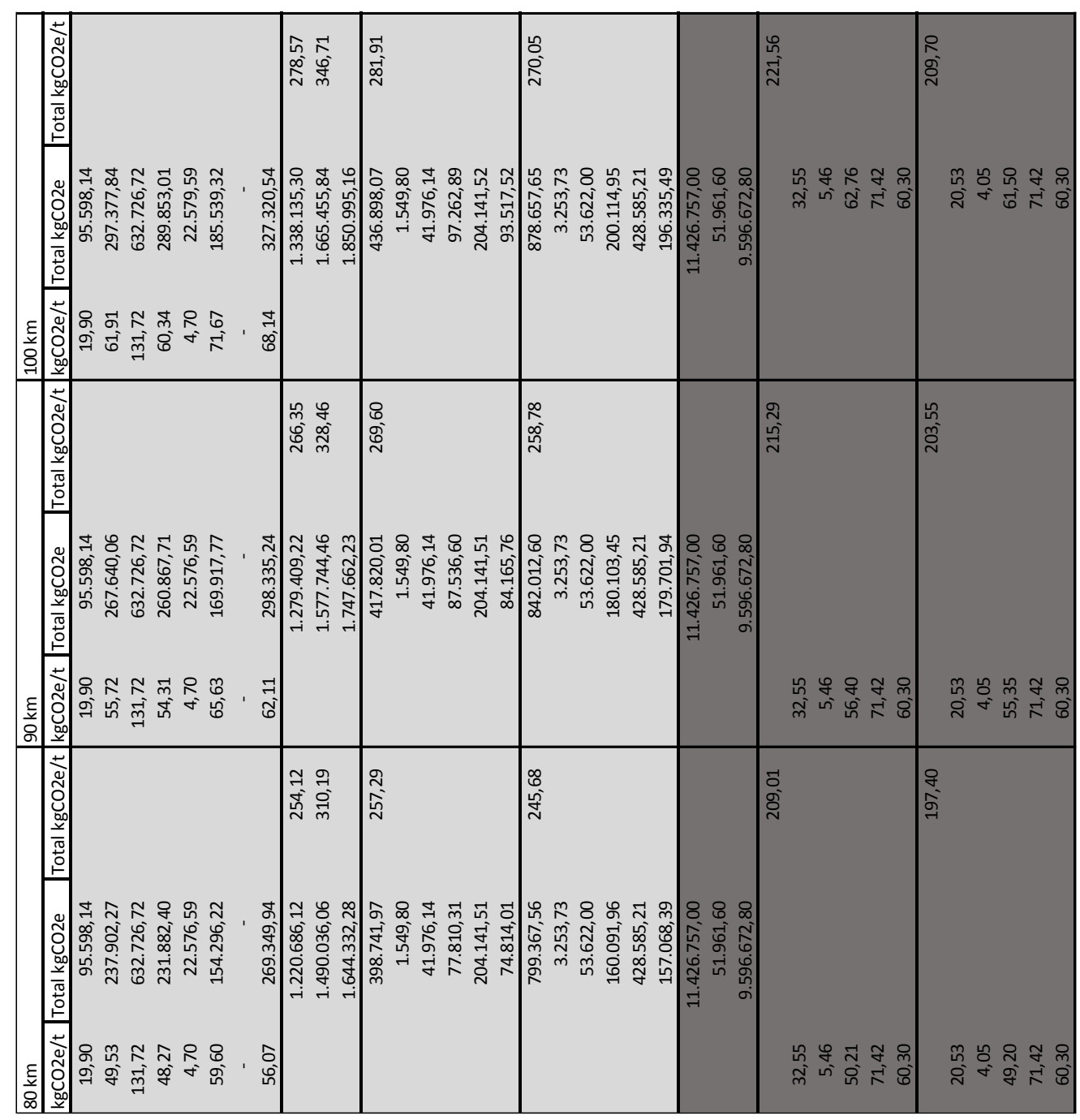




\section{Scenario 5}

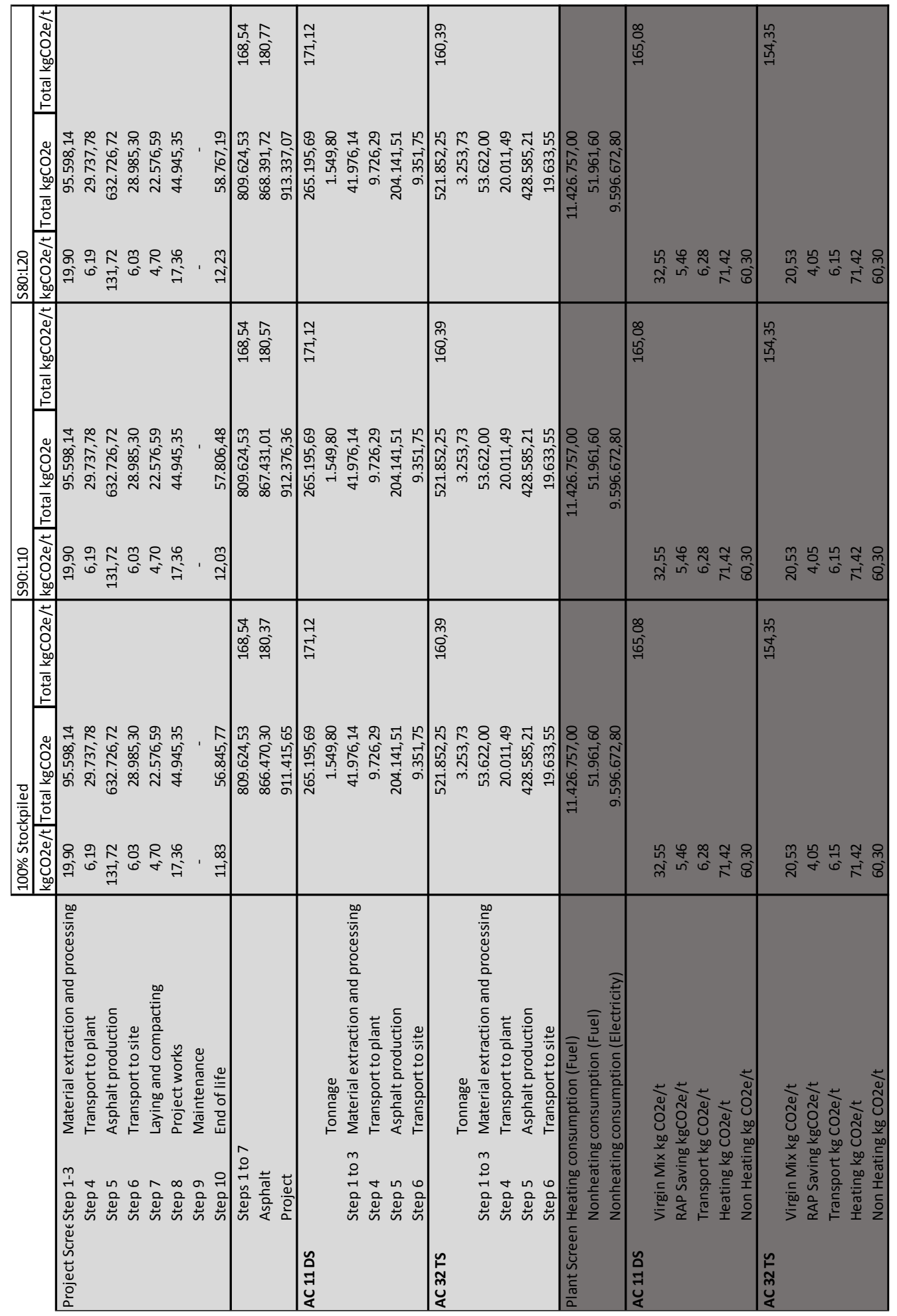




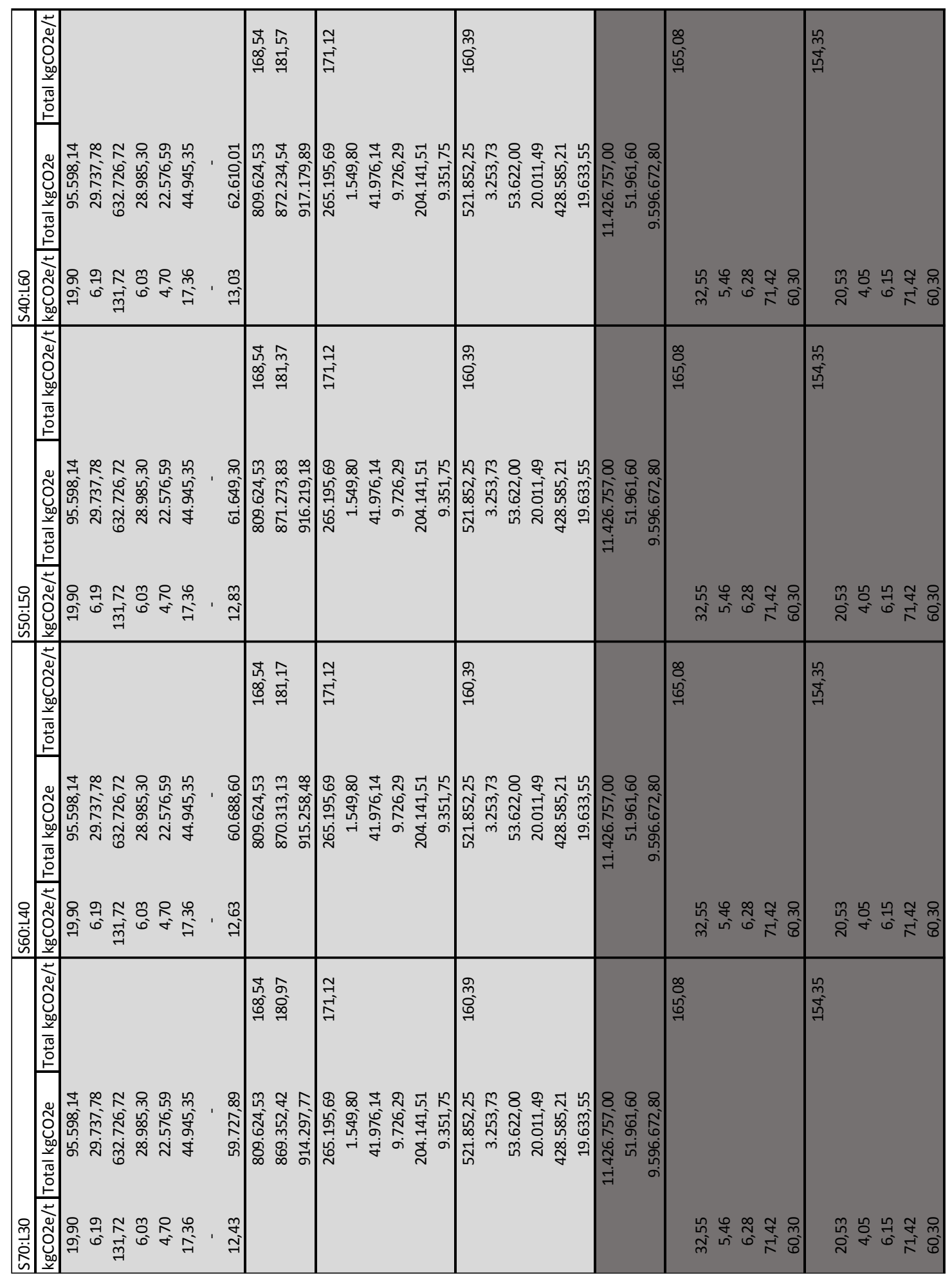




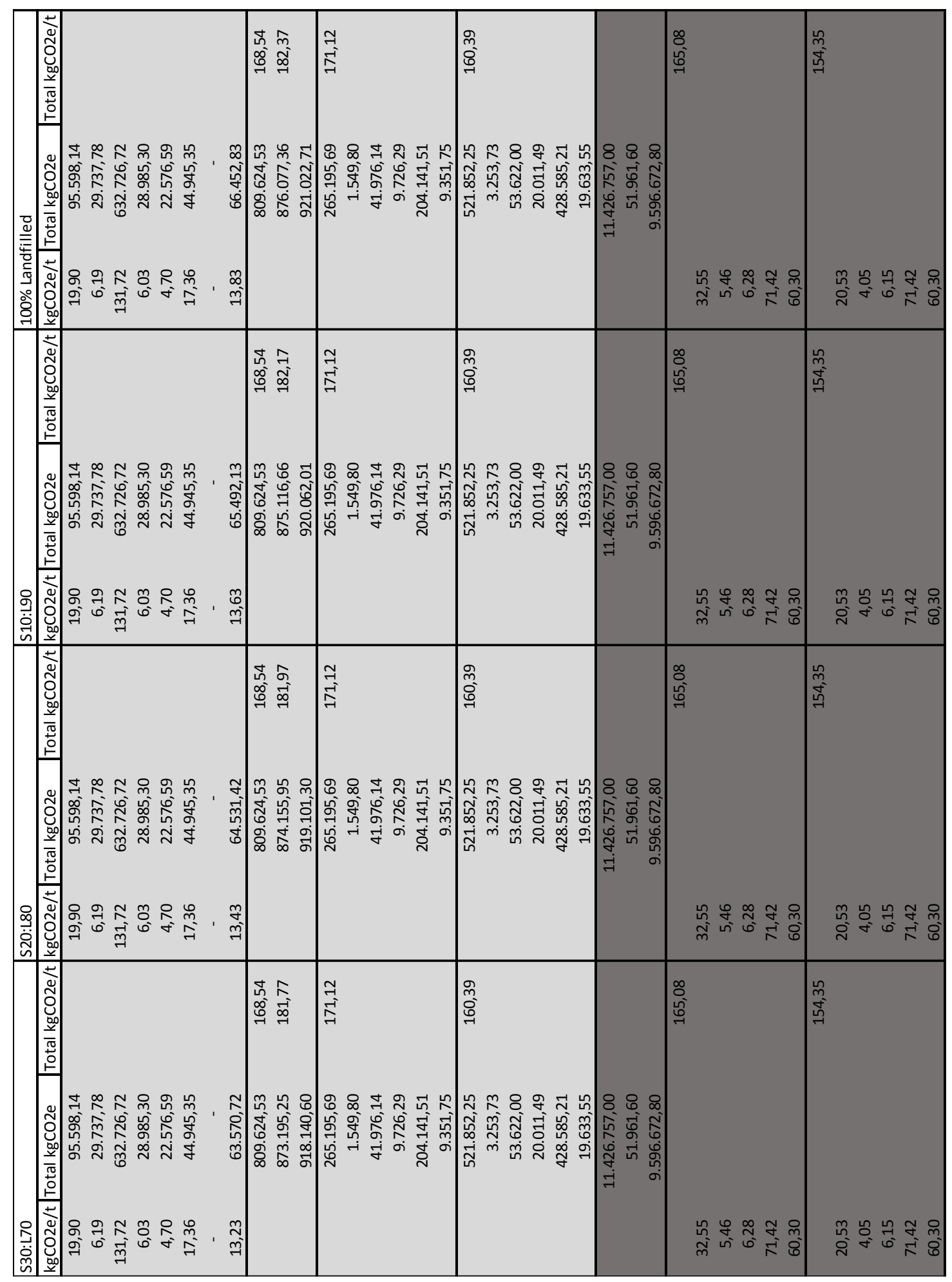




\section{Scenario 6}

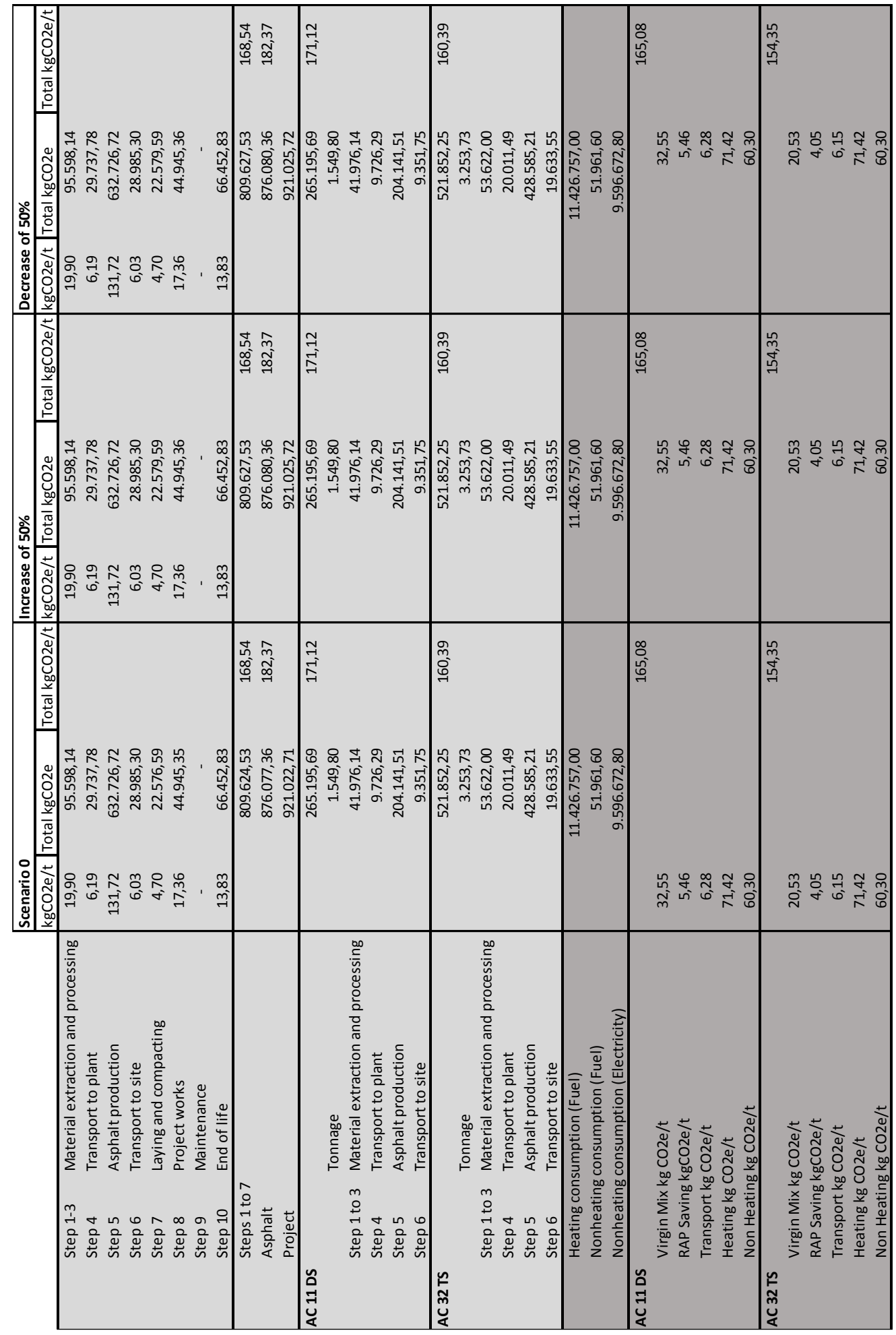




\section{Result Athena Pavement LCA}

Scenario 0

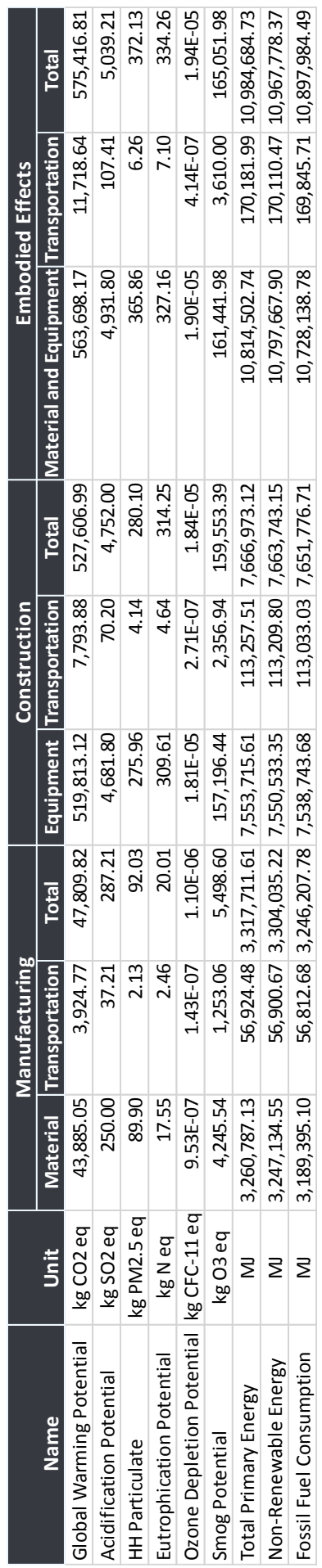


Scenario 1

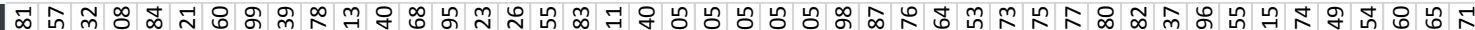

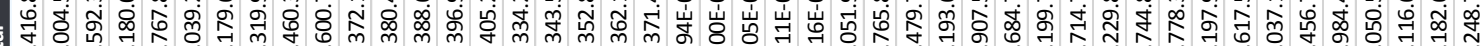

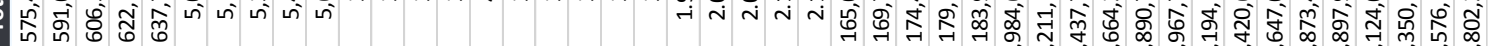

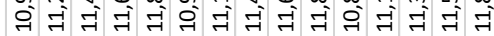
古称

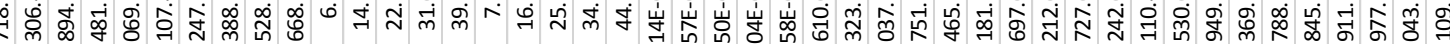

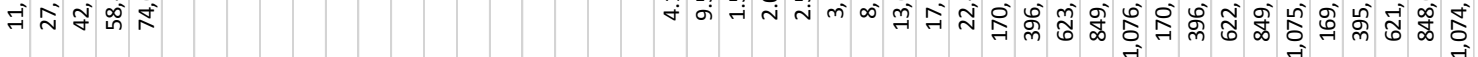

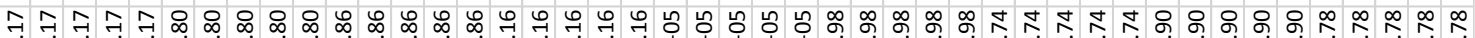

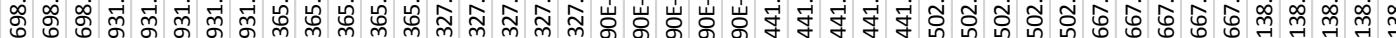

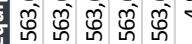

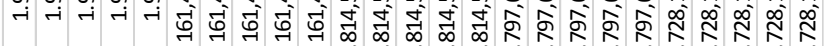

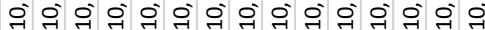

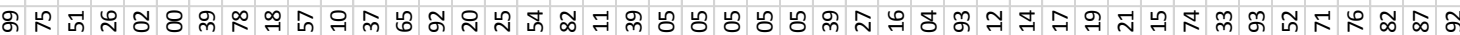

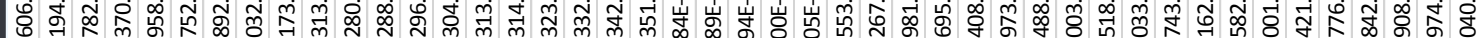

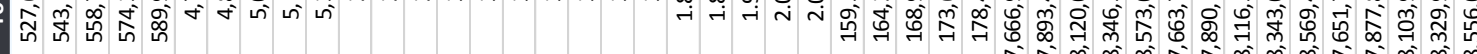
동

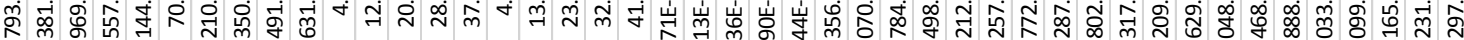

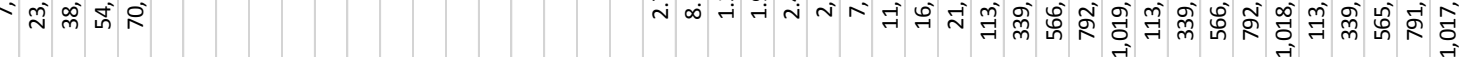

국궁 \&

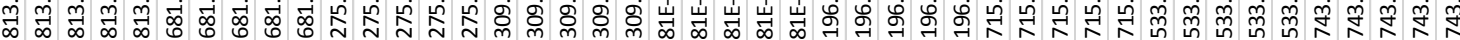

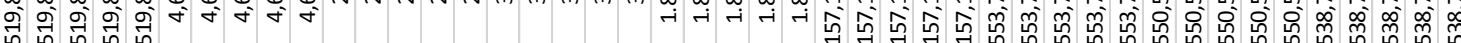

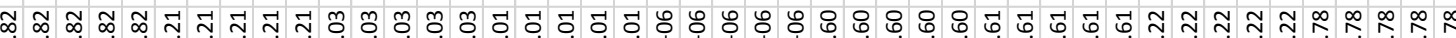

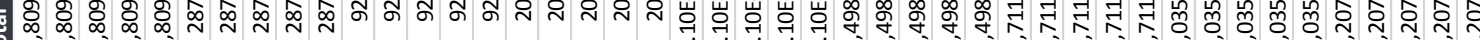

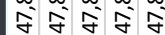

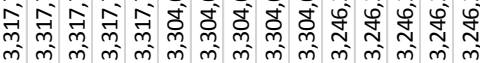

RトRトR

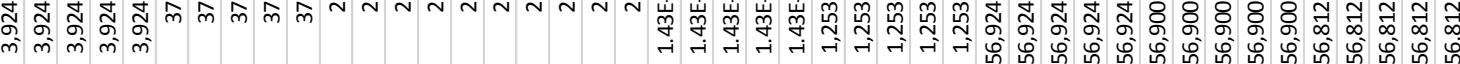

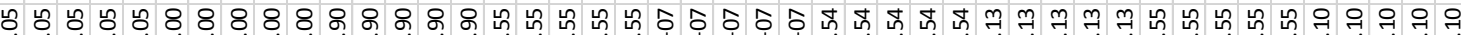

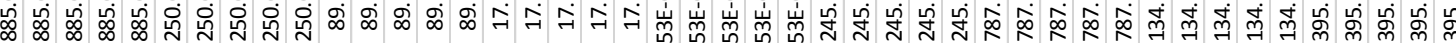

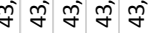

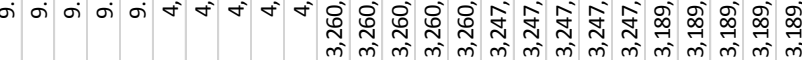

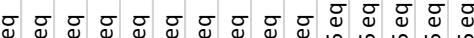

ब

ब

ठิ

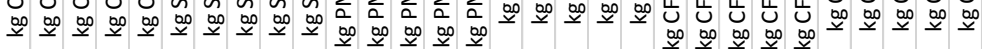

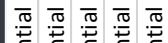

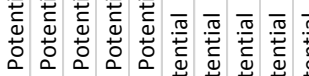

no

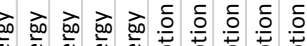

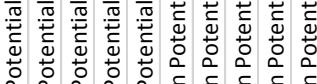

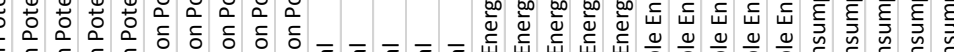

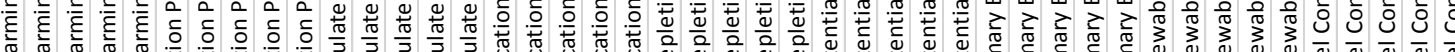

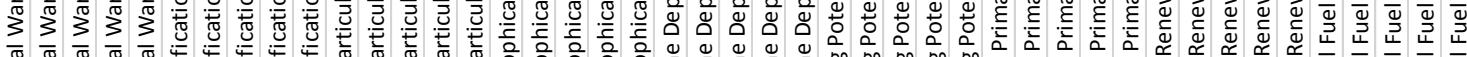

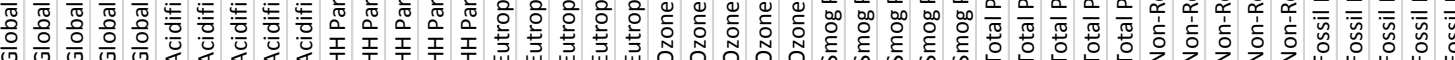

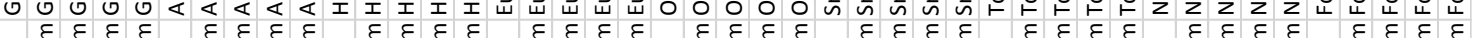

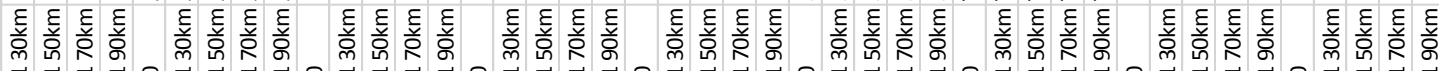

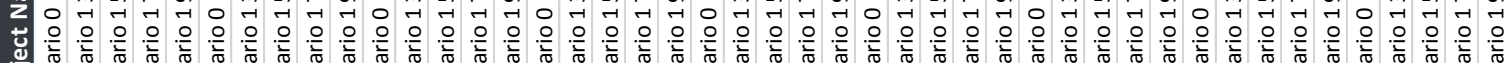

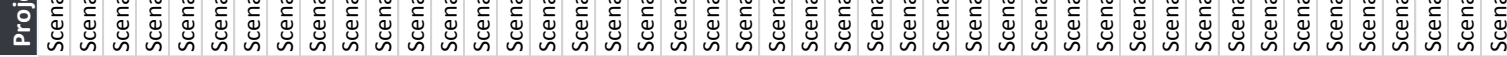




\section{Scenario 2}

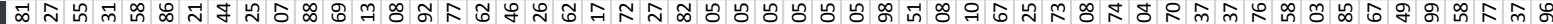

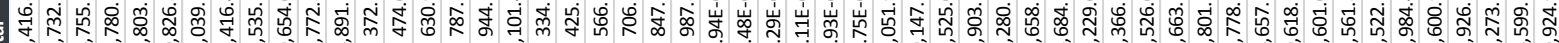

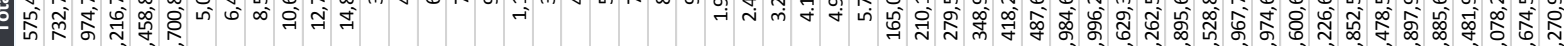

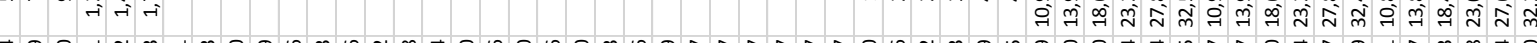

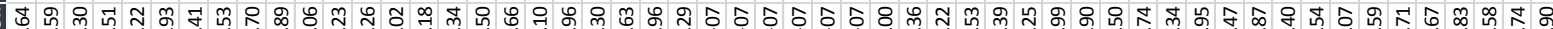

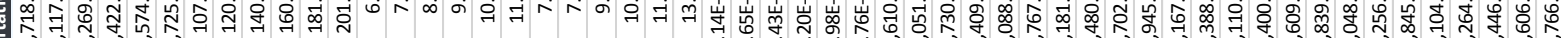
تี่ ติ่

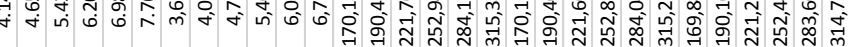

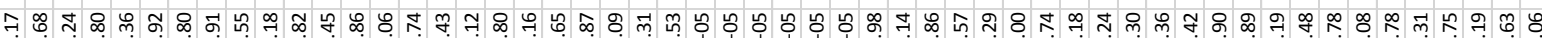

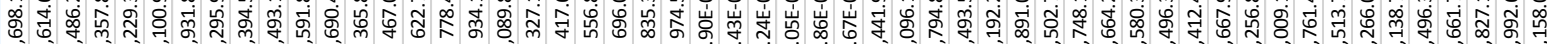

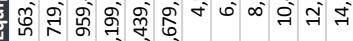

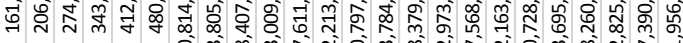

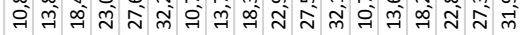

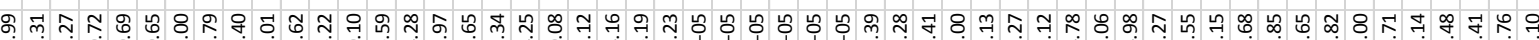
\&

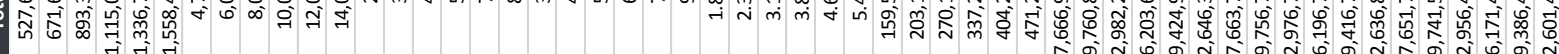
㑒

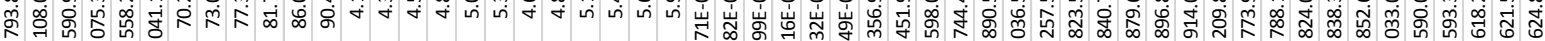
is

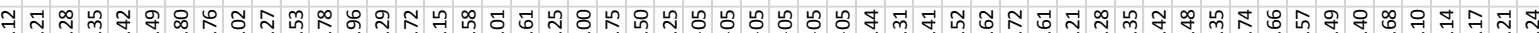
ळ

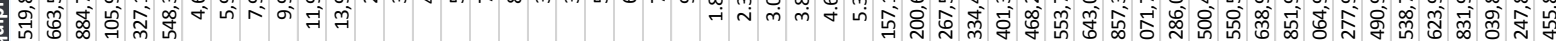
๘

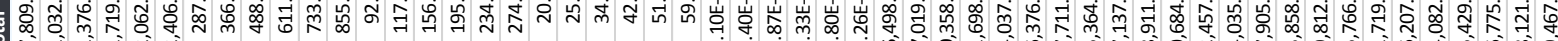

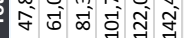
西

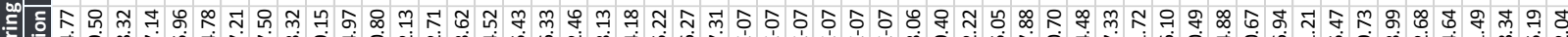

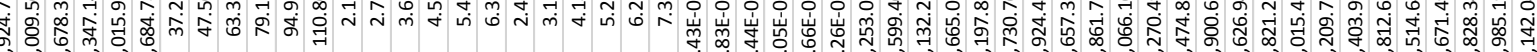

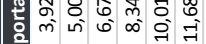

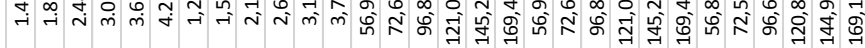

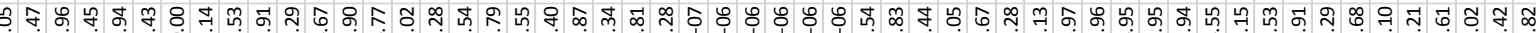

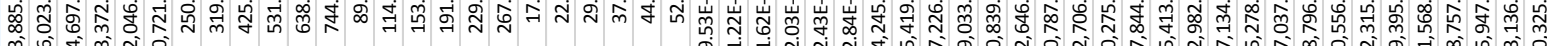

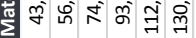

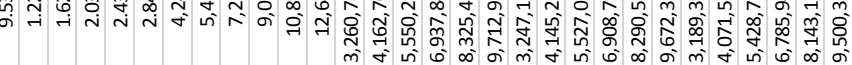

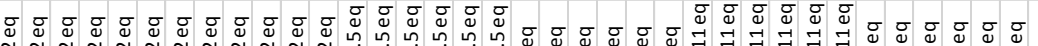

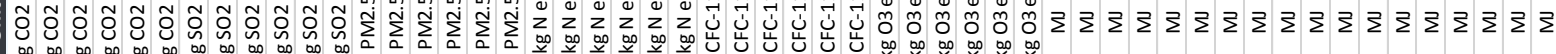

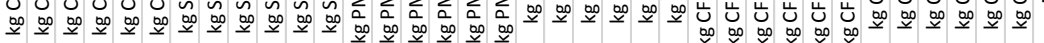

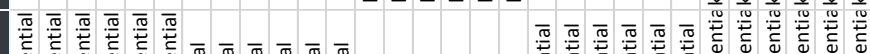

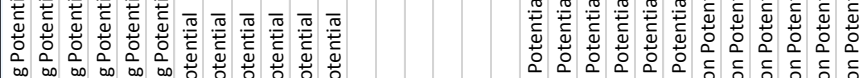

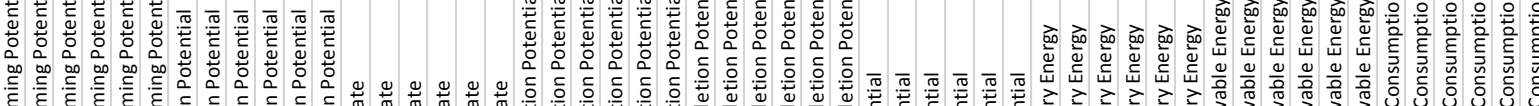

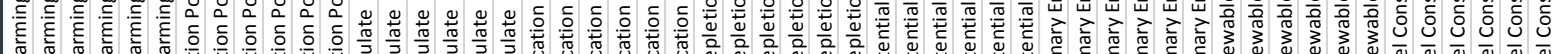

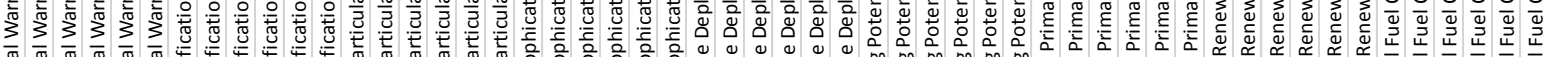

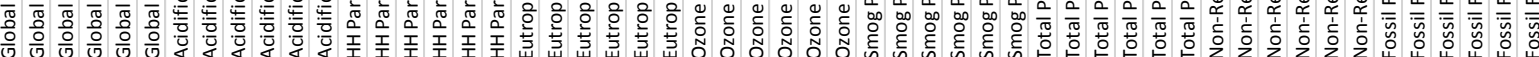

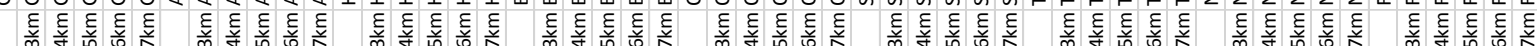

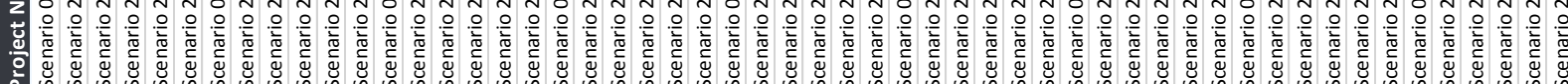




\section{Results SEVE Eco-Comparateur}

\section{Scenario 0}

Scenario 0

\begin{tabular}{|c|c|c|c|c|c|c|c|c|c|}
\hline Code & Name & Unit of work & Raw material & $\begin{array}{l}\text { Upstream } \\
\text { transport }\end{array}$ & Manufacturing & Transport. site & Application & Others & Total \\
\hline EN & Energy & Mega-Joule & $1,945,958.86$ & $224,814.74$ & $1,301,072.25$ & $102,580.81$ & $379,076.00$ & - & $3,953,502.65$ \\
\hline $\mathrm{CO}$ & $\mathrm{CO} 2$ & ton & 100.53 & 18.09 & 103.33 & 8.26 & 29.68 & - & 259.89 \\
\hline GN & Natural & ton & $6,228.02$ & - & - & - & - & - & $6,228.02$ \\
\hline$A E$ & RAP & ton & 939.03 & - & - & - & - & - & 939.03 \\
\hline TK & Tonne & Ton Kilometer & - & - & - & - & - & - & - \\
\hline
\end{tabular}

\section{Scenario 1}

See report attached. [64]

\section{Scenario 2}

Scenario 2 - Energy Consumption

\begin{tabular}{|c|c|c|c|c|c|c|c|}
\hline Solution & Materials & $\begin{array}{c}\text { Upstream } \\
\text { transportation }\end{array}$ & $\begin{array}{c}\text { Manufacturing } \\
\text { mixtures }\end{array}$ & $\begin{array}{l}\text { Haul to } \\
\text { construction site }\end{array}$ & Lay down & Total & $\begin{array}{c}\text { Comparison } \\
\text { / Base }\end{array}$ \\
\hline $100 \%$ & $1,945,958.86$ & $224,814.74$ & $1,301,072.25$ & $512,904.03$ & $379,076.00$ & $4,363,825.88$ & $0 \%$ \\
\hline $150 \%$ & $1,945,958.86$ & $224,814.74$ & $1,301,072.25$ & $512,904.03$ & $575,478.00$ & $4,560,227.88$ & $5 \%$ \\
\hline $200 \%$ & $1,945,958.86$ & $224,814.74$ & $1,301,072.25$ & $512,904.03$ & $758,152.00$ & $4,742,901.88$ & $9 \%$ \\
\hline $250 \%$ & $1,945,958.86$ & $224,814.74$ & $1,301,072.25$ & $512,904.03$ & $954,554.00$ & 4,939,303.88 & $13 \%$ \\
\hline
\end{tabular}

Scenario 2 - $\mathrm{CO}_{2} \mathrm{e}$ Emissions

\begin{tabular}{|c|c|c|c|c|c|c|c|}
\hline Solution & Materials & $\begin{array}{c}\text { Upstream } \\
\text { transportation }\end{array}$ & $\begin{array}{c}\text { Manufacturing } \\
\text { mixtures }\end{array}$ & $\begin{array}{c}\text { Haul to } \\
\text { construction site }\end{array}$ & Lay down & Total & $\begin{array}{c}\text { Comparison } \\
\text { / Base }\end{array}$ \\
\hline $100 \%$ & 100.53 & 18.09 & 103.33 & 41.28 & 29.68 & 292.91 & $0 \%$ \\
\hline $150 \%$ & 100.53 & 18.09 & 103.33 & 41.28 & 45.04 & 308.27 & $5 \%$ \\
\hline $200 \%$ & 100.53 & 18.09 & 103.33 & 41.28 & 59.36 & 322.59 & $10 \%$ \\
\hline $250 \%$ & 100.53 & 18.09 & 103.33 & 41.28 & 74.72 & 337.95 & $15 \%$ \\
\hline
\end{tabular}




\section{References}

[1] Ministry for Transport and Digital Infrastructure, "Bundesverkehrswegeplan 2030," https://www.bmvi.de/SharedDocs/DE/Publikationen/G/bundesverkehrswegeplan-2030gesamtplan.pdf?_blob=publicationfile, 2016.

[2] United Nations, "The Future we want: final document of the Rio+20 Conference," http://rio20.net/wp-content/uploads/2012/06/N1238164.pdf, 2012.

[3] eurostat, "Sustainable development in the European Union: 2015 monitoring report of the EU Sustainable Development Strategy," 2015.

[4] D. H. Meadows, the limits to growth: A report for the Club of Rome's project on the predicament of mankind / Donella H. Meadows ... [et al.]. New York: Universe Books, 1972 .

[5] D. H. Meadows, J. Randers, and D. Meadows, A Synopsis: Limits to Growth: The 30Year Update: Chelsea Green Publishing, 2004.

[6] G. Turner and C. Alexander, "Limits to Growth was right. New research shows we're nearing collapse," The Guardian, 02 Sep., 2014,

https://www. theguardian.com/commentisfree/2014/sep/02/limits-to-growth-was-rightnew-research-shows-were-nearing-collapse.

[7] United Nations Environment Programme, "Declaration of the United Nations Conference on the Human Environment," United Nations Environment Programme. [Online] Available:

http://www. unep.org/documents.multilingual/default.asp?documentid=97\&articleid=15 03. Accessed on: Jul. 162016.

[8] World Commission on Environment and Development, "Report of the World Commission on Environment and Development: Our Common Future," World Commission on Environment and Development, 1987. [Online] Available: http://www.undocuments.net/our-common-future.pdf. Accessed on: Jul. 162016.

[9] Federal Ministry for the Environment, Nature Conservation, Building and Nuclear Safety, Climate - Energy: United Nations Framework Convention on Climate Change. [Online] Available: http://www.bmub.bund.de/en/topics/climateenergy/climate/international-climate-policy/united-nations-framework-conventionon-climate-change-unfccc/. Accessed on: Jul. 162016.

[10] United Nations, "United Nations Conference on Environment and Development," United Nations, 1997. [Online] Available: http://www.un.org/geninfo/bp/enviro.html. Accessed on: Jul. 162016.

[11] Federal Ministry for the Environment, Nature Conservation, Building and Nuclear Safety, Climate - Energy: Climate Conferences. [Online] Available: http://www.bmub.bund.de/en/topics/climate-energy/climate/international-climate- 
policy/climate-conferences/chronicle-of-climate-changeconferences/?cHash=708635c8a9f766bc5d0c165b53867c44. Accessed on: Jul. 162016.

[12] Federal Ministry for the Environment, Nature Conservation, Building and Nuclear Safety, Climate - Energy: Kyoto Protokol. [Online] Available:

http://www.bmub.bund.de/en/topics/climate-energy/climate/international-climatepolicy/climate-conferences/chronicle-of-climate-changeconferences/?cHash=708635c8a9f766bc5d0c165b53867c44. Accessed on: Jul. 162016.

[13] Marianne Beisheim, "2030 Agenda für nachhaltige Entwicklung: Mehr als nur eine Liste frommer Wünsche," 24 Sep., 2015, http://www.swpberlin.org/publikationen/kurz-gesagt/2030-agenda-fuer-nachhaltige-entwicklungmehr-als-eine-liste-frommer-wuensche.html.

[14] United Nations Treaty Collection, CHAPTER XXVII ENVIRONMENT: 7.d Paris Agreement. [Online] Available:

https://treaties.un.org/Pages/ViewDetails.aspx?src=TREATY\&mtdsg_no=XXVII-7d\&chapter=27\&clang=_en. Accessed on: Nov. 122016.

[15] A. Endres, "Klimagipfel Paris: Die Zeitenwende von Le Bourget," Zeit Online, 13 Dec., 2015, http://www.zeit.de/wirtschaft/2015-12/klimagipfel-parisweltklimavertrag-cop21-francois-hollande.

[16] S. Dröge and O. Geden, "Nach dem Pariser Klimaabkommen: Neue Herausforderungen für eine Vorreiterrolle der EU," SWP-Aktuell, 03.2016, 2016, http://www.swpberlin.org/publikationen/swp-aktuell-de/swp-aktuelldetail/article/nach_dem_pariser_klimaabkommen.html.

[17] S. Schwarz, "Zwei zu null gegen Kohle," Blätter für deutsche und interantionale Politik, 07.2016, pp. 13-16, 2016, https://www.blaetter.de/archiv/jahrgaenge/2016/juli/zwei-zu-null-gegen-die-

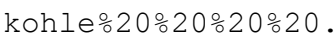

[18] BUND Friends of the Earth Germany, Mehr Mobilität mit weniger Verkehr nachhaltig, effizient, machbar. [Online] Available: http://www.bund.net/themen_und_projekte/mobilitaet/infrastruktur/. Accessed on: Aug. 092016.

[19] M. Kamann, "Dobrindts Verkehrs-Masterplan kostet 264 Milliarden," Die Welt, 16 Mar., 2016, http://www.welt.de/politik/deutschland/article153371382/DobrindtsVerkehrs-Masterplan-kostet-264-Milliarden.html.

[20] N. Stern, The economics of climate change: The Stern review - Executive Summary. [Online] Available: http: //siteresources.worldbank.org/INTINDONESIA/Resources/2262711170911056314/3428109-1174614780539/SternReviewEng.pdf. Accessed on: Jul. 21 2016. 
[21] Cambridge University Press, Academic: The Economics of Climate Change - The Stern Review. [Online] Available: http://www.cambridge.org/de/academic/subjects/earthand-environmental-science/climatology-and-climate-change/economics-climatechange-stern-review. Accessed on: Jul. 212016.

[22] R. Neate, "Rockefeller family charity to withdraw all investments in fossil fuel companies," The Guardian, 23 Mar., 2016, https://www.theguardian.com/environment/2016/mar/23/rockefeller-fund-divestmentfossil-fuel-companies-oil-coal-climate-change.

[23] Klein Naomi, "Die Entscheidung: Kapital vs. Klima," Blätter für deutsche und interantionale Politik, 05.2015, pp. 43-57, 2015, https://www.blaetter.de/archiv/jahrgaenge/2015/mai/die-entscheidung-kapital-vs.klima.

[24] F. Ekardt, "Nicht die Konzerne - wir selbst sind das Problem," Zeit Online, 11 Mar., 2015, http://www.zeit.de/wirtschaft/2015-03/naomi-klein-kapitalismusklimawandel.

[25] Deutscher Asphaltverband, Ed., Wiederverwendung von Asphalt. Bonn: DAV, 2014.

[26] A. Alvarez Castro, "LCE4ROADS project newsletter," vol. August 2015, http: //www. fehrl.org/ ?m=32\&mode=download\&id_file=18223.

[27] ACCIONA Infraestructuras, I Life Cycle Engineering approach to develop a novel EU-harmonized sustainability certification system for cost-effective, safer and greener road infrastructures. [Online] Available: http://ecolabelproject.eu/. Accessed on: Nov. 072016.

[28] Indicators for the sustainability assessment of roads, CEN/TC WI: 2016 (E), 2016.

[29] Richtlinien für die Anlage von Landstraßen, RAL 12, 2012.

[30] T. Brinkhoff, Citypopulation. [Online] Available: http://www.citypopulation.de/php/germany-badenwurttemberg_d.php?cityid=08215099. Accessed on: Sep. 112016.

[31] Stadtverwaltung Stutensee, Unsere Stadt: Daten \& Fakten. [Online] Available: http://www.stutensee.de/unsere-stadt/daten-fakten/. Accessed on: Sep. 112016.

[32] Stadtverwaltung Stutensee, Ehem. L560 nach Graben wegen Sanierung gesperrt. [Online] Available: https://www.meinstutensee.de/2015/09/ehem-1560-nach-grabenwegen-sanierung-gesperrt/. Accessed on: Sep. 112016.

[33] Federal Agency for Cartography and Geodesy, Germany. Frankfurt am Main: Federal Agency for Cartography and Geodesy, 2016.

[34] Landesamt für Umwelt, Messungen und Naturschutz Baden-Württemberg, Steckbrief "Bituminöser/teerhaltiger Straßenaufbruch". Karlsruhe, 2007.

[35] Stadtverwaltung Stutensee, K3533 zwischen Friedrichstal und Graben wieder befahrbar. [Online] Available: https://www.meinstutensee.de/2015/11/k3533zwischen-friedrichstal-und-graben-wieder-befahrbar/. Accessed on: Nov. 052016. 
[36] BGL Baugeräteliste 2015: Technisch-wirtschaftliche Baumaschinendaten, 1st ed. Gütersloh, Gütersloh: Bauverl., 2015.

[37] Environmental management - Life cycle assessment - Principles and framework, DIN EN ISO 14040:2006, 2012.

[38] Environmental management - Life cycle assessment - Requirements and guidelines, DIN EN ISO 14044:2006, 2006.

[39] Sustainability of construction works - Environmental product declarations - Core rules for the product category of construction products, DIN EN $15804: 2012+A 1: 2013,2014$.

[40] Sustainability of construction works - Assessment of buildings - Part 2: Framework for the assessment of nvironmental performance, DIN EN 15643-2:2011, 2012 .

[41] Conference of European Directors of Roads, "EDGAR Evaluation and Decision Preocess of Greener Asphalt Roads: Recommended Product Category Rules (PCRs) for bituminous materials and technologies," https://www.ntnu.edu/documents/701369389/0/Recommended+Product+Category+Rules+(PC Rs) +for+bituminous+materialstand+technologies+(D2-1) ppdf / 9a 7cd751-4676-4caf-af34$8 \mathrm{~d} 3870 \mathrm{def} 174,2014$.

[42] Nachhaltigkeitsbeurteilung von Strasseninfrastrukturprojekten; Grundnorm, SN 641 800,2008 .

[43] U. Seewer, "Ziel- und Indikatorensystem nachhaltiger Verkehr UVEK (ZINV UVEK)," 2001 .

[44] F. Walter, C. Lieb, and H. Simmen, "Nachhaltigkeitsbeurteilung des Bundes bei Strassenprojekten: NISTRA," Umweltrecht in der Praxis, vol. 20, no. 5, 2006.

[45] Nachhaltigkeitsbeurteilung von Strasseninfrastrukturprojekten - Nutzwertanalyse und Kosten-Wirksamkeits-Analyse, SN 641 810, 2014.

[46] Federal Ministry for the Environment, Nature Conservation, Building and Nuclear Safety, Datenbank: ÖKOBAU.DAT. [Online] Available: www.bmub.bund.de/P3231/. Accessed on: Oct. 222016.

[47] Federal Ministry for the Environment, Nature Conservation, Building and Nuclear Safety, ÖKOBAU.DAT: Informationsportal nachhaltiges Bauen. [Online] Available: http://www.oekobaudat.de/. Accessed on: Oct. 162016.

[48] Defra, "Environmental Reporting Guidelines: Including Mandatory Greenhouse Gas Emissions Reporting Guidance," 2013.

[49] Athena Sustainable Materials Institute, Our Software \& Data. [Online] Available: http://www.athenasmi.org/our-software-data/overview/. Accessed on: Nov. 052016.

[50] T. Ebert, N. Eßig, and G. Hauser, Zertifizierungssysteme für Gebäude: Nachhaltigkeit bewerten, internationaler Systemvergleich, Zertifizierung und 
Ökonomie, 1st ed. München: Inst. für Internat. Architektur-Dokumentation, 2010, 2010 .

[51] BREEAM, BREEAM: Home. [Online] Available: http://www.breeam.com/. Accessed on: Nov. 172016.

[52] LEED, This is LEED: Better buildings are our legacy. [Online] Available: http://leed.usgbc.org/leed.html. Accessed on: Nov. 172016.

[53] M Wayman, I Schiavi-Mellor and B Cordell, "Protocol for the Calculation of Whole Life Cycle Greenhouse Gas Emissions Generated by Asphalt,"

[54] M Wayman, I Schiavi-Mellor and B Cordell, "Further Guidance on the Calculation of Whole Life Cycle Greenhouse Gas Emission Generated by Asphalt,"

[55] TRL, asPECT: Transport Research Laboratory, 2014.

[56] US Environmental Protection Agency, Understanding Global Warming Potentials. [Online] Available: https://www.epa.gov/ghgemissions/understanding-globalwarming-potentials. Accessed on: Sep. 202016.

[57] Specification for the assessment of the life cycle greenhouse gas emissions of goods and services, PAS 2050, 2011.

[58] Department for Environment, Food and Rural Affairs and Department of Energy and Climate Change, UK Governement GHG Conversion Factors for Company Reporting. Available: https://www.gov.uk/government/publications/greenhouse-gas-reportingconversion-factors-2016. Accessed on: Sep. 202016.

[59] Athena Sustainable Materials Institute, Impact Estimator for Highways: User Guide. [Online] Available: http://calculatelca.com/wpcontent/uploads/2016/04/PavementLCA_UserGuide.pdf. Accessed on: Oct. 192016.

[60] US Environmental Protection Agency, Tool for the Reduction and Assessment of Chemical and Other Environmental Impacts (TRACI): TRACI Version 2.1 - User's Guide. [Online] Available: https://nepis.epa.gov/Adobe/PDF/P100HN53.pdf. Accessed on: Nov. 052016.

[61] R. Venditti, "Environmental Life Cycle Assessment: Lecture 11: TRACI Impact Assessment Method," 2012.

[62] eurostat, Statistics Explained: Energy glossary. [Online] Available: http://ec.europa.eu/eurostat/statistics-explained/index.php/Category: Glossary . Accessed on: Nov. 012016.

[63] US Energy Inforamtion Administration, Nonrenewable and renewable energy sources: Your Guide To Understanding Energy. [Online] Available: http://www.eia.gov/energyexplained/?page=nonrenewable_home. Accessed on: Nov. 01 2016 .

[64] usirf, SEVE - ECO Comparateur. Online tool: usirf, 2013. 
[65] usirf, "Assessment System for Ecological Technical Alternatives (SEVE): User's guidebook," http://international.seve-tp.com/Documents/Manuel_SEVE_072010.pdf, 2010 .

[66] SEVE, Plaquette - SEVE Environmental Alternatives Evaluation System. Available: http://www.usirf.com/wp-content/uploads/SEVE_2016_GB.pdf. Accessed on: Oct. 06 2016 .

[67] Umwelt Bundesamt, Treibhausgas-Emissionen in Deutschland. [Online] Available: https://www. umweltbundesamt. de/daten/klimawandel/treibhausgas-emissionen-indeutschland. Accessed on: Nov. 012016.

[68] Government of Canada, Environment and Climate Change Canada: Greenhouse Gas Emissions. [Online] Available: https://ec.gc.ca/indicateursindicators/default.asp?lang=en\&n=FBF8455E-1. Accessed on: Nov. 012016.

[69] World Road Association, "Integration of Performance Indicators," http://www.piarc.org/ressources/publications/4/5900,TM2008R06.pdf, 2008. 